\title{
Revision of the subgenus Lampetis (Spinthoptera) (Coleoptera: Buprestidae) of North and Central America, and the West Indies
}

\author{
ANGÉliCa Ma. CORONA \\ Museo de Zoología “Alfonso L. Herrera”, Facultad de Ciencias, UNAM, Apartado Postal 70-399, 04510 México, D.F., México; \\ e-mail: amc1@minervaux2.fciencias.unam.mx
}

Key words. Coleoptera, Buprestidae, Lampetis (Spinthoptera), taxonomy, new species, new synonymy, North America, Central America, West Indies

\begin{abstract}
The species of Lampetis (Spinthoptera) Casey, 1909 of Central America, North America and the West Indies are revised and 31 species are recognized. Six species from the West Indies [L. aurata (Saunders, 1871), L. aurifera (Olivier, 1790), L. bahamica (Fisher, 1925), L. guildini (Laporte \& Gory, 1836), L. straba (Chevrolat, 1867), and L. torquata (Dalman, 1823)], eight species from Mexico [L. auropunctata (Kerremans, 1893) (new record for the USA), L. chalconota (Waterhouse, 1882), L. christophi Théry, 1923, L. dilaticollis (Waterhouse, 1882), L. geniculata (Waterhouse, 1889), L. granulifera (Laporte \& Gory, 1837), L. mexicana Théry, 1923, and L. obscura Thomson, 1879], three species from Mexico and Central America [L. cortesi (Laporte \& Gory, 1837), L. monilis (Chevrolat, 1834), L. simplex (Waterhouse, 1882)], and three from Central America [L. hirtomaculata $($ Herbst, 1801) $=$ L. insularis (Casey, 1909) syn. n.; L. lesnei (Kerremans, 1910); and L. srdinkoana (Obenberger, 1924)] are redescribed. Seven new species (L. chamela sp. n., L. colima sp. n., L. cyanitarsis sp. n., L. hondurensis sp. n., L. tigrina sp. n., L. viridicolor sp. n., and L. viridimarginalis sp. n.) are described. Three species from Mexico and the United States $[$ L. cupreopunctata (Schaeffer, 1905$), L$. drummondi (Laporte \& Gory, 1836), and L. webbii (LeConte, 1858)], and one species from Mexico (L. chiapaneca Corona, 2004) are not described here, because they were (re)described recently. The diagnosis, distribution, host plants and phenology data of $L$. chiapaneca, L. cupreopunctata, L. drummondi, and L. webbii are given. Lampetis famula Chevrolat, 1838 and L. variolosa (Fabricius, 1801) are not recognized herein as Mexican species, because they are from South America according to the literature and specimens studied. Information on variation, distribution, and host plants are given for each species. Photographs of dorsal habitus and male genitalia are included.
\end{abstract}

\section{INTRODUCTION}

The genus Lampetis Dejean, 1833 (Coleoptera: Buprestidae) was formerly considered a subgenus of Psiloptera Dejean, 1833, until Kurosawa (1993) divided Psiloptera into six genera, one being Lampetis. Bellamy (1998a) clarified the authorship of certain buprestid genera, accepting Psiloptera Dejean, 1833 and Lampetis Dejean, 1833. Lampetis is one of the most speciose genera in the subtribe Dicercina according to Bellamy (2003), with approximately 251 species widely distributed in the Andean, Afrotropical, Nearctic, Neotropical, Oriental and Palearctic regions. According to Kurosawa (1993), all species in the New World belong to the subgenus Spinthoptera Casey, 1909.

According to the literature (Blackwelder, 1944; Bellamy, 1985), 10 species of Lampetis (Spinthoptera) are known from North America [L. auropunctata (Kerremans, 1893), L. chalconota (Waterhouse, 1882), L. christophi Théry, 1923, L. cupreopunctata (Schaeffer, 1905), L. dilaticollis (Waterhouse, 1882), L. drummondi (Laporte \& Gory, 1836), L. geniculata (Waterhouse, 1889), L. mexicana Théry, 1923, L. obscura Thomson, 1879, and L. webbii (LeConte, 1858)], four species are from Mexico and Central America [L. cortesi (Laporte \& Gory, 1837), L. granulifera (Laporte \& Gory, 1837), L. monilis (Chevrolat, 1834), and L. simplex (Waterhouse, 1882)], three species are known only from Central America [L. hirtomaculata (Herbst, 1801), L. lesnei (Ker- remans, 1910), and L. srdinkoana (Obenberger, 1924)], and six species are known from the West Indies [ $L$. aurata (Saunders, 1871), L. aurifera (Olivier, 1790), L. bahamica (Fisher, 1925), L. guildini (Laporte \& Gory, 1836), L. straba (Chevrolat, 1867), and L. torquata (Dalman, 1823)]. Recently, Nelson (1986) reviewed three species of Lampetis from the United States $[L$. cupreopunctata (Schaeffer, 1905), L. drummondi (Laporte \& Gory, 1836), and L. webbii (LeConte, 1858)], and Corona (2004) published a new species from Mexico (L. chiapaneca), but nobody has undertaken a complete taxonomic study of all species of Lampetis (Spinthoptera) since Kerremans (1910).

I worked with this group during my $\mathrm{PhD}$ thesis and my objective was: (a) to undertake the taxonomic analysis of the species of the Lampetis (Spinthoptera); (b) to redescribe the known species from Mexico, Central America, and the West Indies; (c) to describe new species; and (d) to present information about variation, distribution, and host plants.

\section{MATERIAL AND METHODS}

Altogether 2434 specimens of Lampetis (Spinthoptera) from North and Central America, and the West Indies, as well as type specimens of all the species were provided by 31 institutions and 10 private collections. These collections are abbreviated as in Arnett et al. (1993), except CNIN - Colección Nacional de Insectos, Instituto de Biología, UNAM, Mexico; UAQC Colección de Insectos, Universidad Autónoma de Querétaro, 
Querétaro, Mexico; and MZFC - Colección Entomológica, Museo de Zoologia, Facultad de Ciencias, UNAM. Abbreviations are given as follows: AMNH - American Museum of Natural History, New York, NY, USA; BMNH - The Natural History Museum, London, UK; CASC - California Academy of Sciences, San Francisco, CA, USA; CEAM - Colección Entomológica, Instituto de Fitosanidad, Colegio de Posgraduados, Mexico; CLBC - Charles L. Bellamy collection, Sacramento, CA, USA; CUIC - Cornell University Insect Collection, Ithaca, NY, USA; DSVC - David S. Verity collection, Los Angeles, CA, USA; EAPZ - Escuela Agrícola Panamericana (El Zamorano), Tegucigalpa, Honduras; EBCC - Estación de Biología "Chamela", UNAM, San Patricio, Jalisco, Mexico; EMEC Essig Museum of Entomology, University of California, Berkeley, CA, USA; EMUS - Entomological Museum, Department of Biology, Utah State University, Logan, UT, USA; FMNH Field Museum of Natural History Chicago, IL, USA; FSCACollection of Arthropods, University of Florida, Gainesville, FL, USA; FTHC - Frank Hovore collection, Santa Clarita, CA, USA; GHNC - Gayle H. Nelson collection, Blue Springs, MI, USA; ICIS - Idaho State University, Idaho Museum of Natural History, Pocatello, ID, USA; INBC - Instituto Nacional de Biodiversidad (INBio), Santo Domingo de Heredia, Costa Rica; INIA - Colección de Insectos, Instituto Nacional de Investigaciones Forestales, Agrícolas y Pecuarias, Guanajuato, Mexico; ISNB - Institut Royal des Sciences Naturelles de Belgique, Brussels, Belgium; JEWC - James E. Wappes collection, Bulverde, TX, USA; JMCC - John McCarty collection, San Pablo, CA, USA; LACM - Los Angeles County Museum of Natural History, Los Angeles, CA, USA; MAIC - Michael A. Ivie collection, Bozeman, MT, USA; MCZC - Museum of Comparative Zoology, Harvard University, Cambridge, MA, USA; MHND Museo Nacional de Historia Natural, Santo Domingo, Dominican Republic; MIZA - Universidad Central de Venezuela, Maracay, Venezuela; MZHF - Finnish Museum of Natural History, Helsinki, Finland; NMPC - National Museum, Prague, Czech Republic; RHCP - Roman B. Holynski collection, Milanówek, Poland; RLWE - Richard L. Westcott collection, OR, USA; RMCF - Roy F. Morris collection, Lakeland, FL, USA; SEAN - Museo Entomológico, León, Nicaragua; SEMC - Snow Entomological Museum, University of Kansas, Lawrence, KS, USA; TCMC - Ted C. MacRae collection, St. Louis, MO, USA; UCDC - R.M. Bohart Museum of Entomology, University of California, Davis, CA, USA; UCRC Department of Entomology, University of California, Riverside, CA, USA; UGZM - Colección Zoológica, Universidad de Guadalajara, Guadalajara, Mexico; UMO - Hope Entomological Collections, Oxford University Museum of Natural History, Oxford, UK; USNM - National Museum of Natural History, Smithsonian Institution, Washington D.C., USA; ZMHB Museum für Naturkunde der Humboldt Universitat zu Berlin, Berlin, Germany; ZMUC - Zoological Museum, University of Copenhagen, Copenhagen, Denmark.

External morphological characters were examined using a stereoscopic microscope and measurements were taken using an ocular micrometer. Length measurements were made from the frons of the head to the elytral apex and width across the widest part of the body. Type data are indicated as they appear on the original labels. Separate labels are indicated by brackets ([ ]), each separate line by a slash (/). Localities for distribution under each species are listed alphabetically.

\section{RESULTS}

\section{Genus Lampetis Dejean, 1833}

Lampetis Dejean, 1833: 76; Gistel, 1834: 10; Dejean, 1836: 86; Mannerheim, 1837: 39; Spinola, 1837: 113; Gistel, 1848: 128; Lacordaire, 1857: 27 (syn. of Psiloptera); Gemminger \& Har- old, 1869: 1364 (syn. of Psiloptera); Saunders, 1871: 22; Thomson, 1878: 29; 1879b: 163; Kerremans, 1892: 56; 1893: 106; 1903: 92; Théry, 1905: 39 (as Psiloptera); Obenberger, 1926: 163; Théry, 1946: 54; Obenberger, 1958: 225; Nelson, 1982: 445; Bellamy, 1985: 416; Kurosawa, 1993: 580; Akiyama \& Ohmomo, 1994: 17 (Asian spp. key); Bellamy, 1998a: 369.

Type species: Buprestis bioculata Olivier, 1790 (subsequent designation: Lacordaire, 1857: 30).

Damarsila sensu Kerremans, 1892: 56 (nec Thomson, 1878); 1893: 106; 1903: 95; 1910: 193; Obenberger, 1924b: 9; 1926: 173; Théry, 1948: 5; Bellamy, 1985: 416; Kurosawa, 1993: 580.

Buprestodes Carter, 1924: 23; Carter, 1929: 283; Obenberger, 1930: 419; Bellamy, 1985: 420; Bellamy \& Peterson, 2000: 82 (syn. of Lampetis). Type species: Buprestodes corruscans Carter, 1924 (subs. design. by Bellamy, 1998b).

\section{Subgenus Spinthoptera Casey, 1909}

Spinthoptera Casey, 1909: 71; Kerremans, 1910: 3; Obenberger, 1926: 163; Nelson, 1982: 445; Bellamy, 1985: 416; Nelson, 1986: 274; Kurosawa, 1993: 580.

Type species. Psiloptera valens LeConte, 1858a (orig. design.).

Lampetis sensu Kerremans, 1903: 92 (nec Dejean, 1833); Obenberger, 1958: 225; Nelson, 1986: 274; Kurosawa, 1993: 580.

Diagnosis. Head rugose, frons feebly excavated; clypeus broadly, shallowly emarginate, not separated from frons by carina; antennal cavities large, triangular, with strong oblique ridge above; mandible apices black without punctures. Antennae: short, segment 1 robust, elongate; segments 2 and 3 subglobular, 3 longer than 2; segments 4 and 5 elongate, subequal in length; segment 5 weakly triangular; segments 6-11 serrate, obliquely truncate on toothed border except segment 6 in female, border narrowed more abruptly basally; with sensorial pores along serrate border, in fossae on dorsal and ventral surfaces and at apex ventrally; apical segment without terminal process in either sex. Pronotum: transverse, convex; without raised basal margin; punctuartion coarse; with two small perforate ante-scutellar discal punctures, with weak depression at base near each posterior angle. Elytra: convex; wider at base than pronotum; lateral margins sinuate towards middle, then converging apically; apices narrowly truncate and usually bidentate; disc with rows of distinct punctures. Prosternum: with anterior margin truncate or weakly bisinuate, without median projection or teeth; prosternal process: obtusely angled behind procoxae, largely impunctate and bisulcate. Mesosternum: divided, meso- and metasternum suture obsolete. Metepimeron: triangular, uncovered. Metacoxal plates: dilated medially. Abdomen: with first ventrite flattened or sulcate along midline; apex of last visible ventrite rounded, truncate or feebly emarginate. Legs: with femora only moderately robust; tibiae slender, subcylindrical and straight or weakly arcuate; tarsi robust, first 4 tarsomeres slightly diminishing in length; claws simple. The female differs generally from male as follows: body shape slightly more robust; antenna with segment 6 triangular and not truncate on toothed border; apex of last visible ventrite rounded. 


\section{Key to Central, North American and West Indies species of Lampetis (Spinthoptera)}

1 Pronotum with weak or strong, coarsely and densely punctate, transverse depression along anterior margin; in some species interrupted at middle (Figs 62-66). . . . . . . . 2 Pronotum without previous combination of characteristics; uniformly punctate, some species with few or abundant punctures or without punctures medially (Figs 67-70). . . 6

2 Pronotum with coarsely, densely punctate, transverse depression along posterior margin (in some species interrupted medially) (Figs 65-66)................. 3

- Pronotum without previous combination of characteristics, without entire transverse depression along posterior margin, but with other smaller coarsely, densely punctate impressions (Figs 62-64) . . . . . . . . . . . . . . . . . 4

3 Pronotum with two longitudinal impressions at sides of midline from anterior to posterior margins; pronotum dark brown with cupreous tinge; elytra cupreous sometimes with bluish tinge at apices, callosities reddish, without depression along lateral margins; ventral surface cupreous; punctures red-coppery margined with brassy-green or brassy (Cuba). . . . . . . . . . . . . . . . . . L. straba (Chevrolat, 1867) Pronotum with two transverse arcuate impressions, one along anterior margin, rather broadly interrupted at the middle, the other near posterior margin; each elytron with a depression along lateral margins; entire dorsal surface dark green, punctures and impressions golden-green margined with purple; ventral surface olive-green on median portions, becoming purple toward the sides, punctures golden-green (Cuba, Haiti, Jamaica). . . . . . . L. torquata (Dalman, 1823)

4 Pronotal surface with longitudinal median depression (Fig.

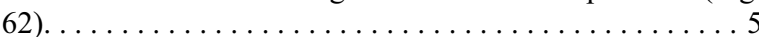

- Pronotal surface without longitudinal median depression and with weak depression along posterior margin near each lateroposterior angle; pronotum and elytra with shining bluish-purplish-cupreous tinge at light; ventral surface dark brown with cupreous and blue tinge, punctures olive-green (Bahamas)............... L. bahamica (Fisher, 1925)

5 Pronotum black with slight bluish-purplish tinge, impressions golden-green; anterior and lateral margins each with entire premarginal depression; elytra reddish dark brown, sometimes red-coppery laterally, punctures cupreous, some callosities with blue or violet tinge; surface with many groups of few small, deep punctures between striae; lateral portion of disc with small callosities and bright green tinge (Dominican Republic, Haiti). . . . L. aurata (Saunders, 1871)

- Entire dorsal surface dark green, sometimes with purplish tinge; ventral surface with strong purple with dark-green and golden-green tinge; dorsal surface impressions and punctures golden-green; impressions with short recurved setae, covered with pale yellow pulverulence in fresh specimens; pronotum with longitudinal median depression sometimes feebly interrupted at middle; another narrow depression along lateral margin but not reaching posterior angles, and one transversely oblique depression behind the middle on each side (Dominican Republic, Haiti, Cuba). ...........

L. aurifera (Olivier, 1790)

6 Abdomen with slender processus intercoxalis of the first ventrite flattened at middle (Fig. 75) . . . . . . . . . 7

- Abdomen with slender processus intercoxalis of the first ventrite slightly concave at middle (Fig. 74) . . . . . . . . 9

7 Elytra with numerous finely punctate interstrial impressions, commonly confluent in transverse groupings; pronotum with or without punctures medially (Fig. 80) . . . . . . . . 8
- Elytra with few finely punctate interstrial impressions, usually isolated from each other; elytral apices usually dark blue; pronotum heavily punctate medially, with lateral margins obliquely converging anteriorly; dorsal surface dark bluish-black with brassy-green punctures, ventral surface dark blue (USA, Mexico). . . . . . L. webbii (LeConte, 1858)

8 Dorsal surface black with blue and violet tinge; ventral surface bluish black; punctures and impressions brassy green or brassy-cupreous; pronotal surface smooth, without punctures medially; pronotal disc with impressed median furrow extending from posterior margin to near anterior margin and with strong, broad depression at midline near posterior margin with blue and violet tinge (Mexico: ChihuahuaOaxaca)............. L. dilaticollis (Waterhouse, 1882)

- Dorsal and ventral surfaces brassy-green, brassy-cupreous, or blue, elytral apices generally brassy-green or brassycupreous; pronotum heavily punctate medially, with lateral margins roundly converging anteriorly and disc convex with distinct broad concave depression in midline at posterior margin in some specimens (USA, northern Mexico) . . . . . . . L. drummondi (Laporte \& Gory, 1836)

9 Pronotum with a strong bead-like line of punctures along

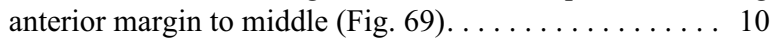
Pronotum uniformly punctate (Figs 67, 70) . . . . . . 20

10 Pronotum with longitudinal concavity along midline (Fig.

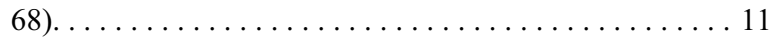

- Pronotum flattened along midline. ............ 12

11 General dorsal coloration black with impressions and punctures cupreous, ventral surface cupreous; elytral disc with striae moderately impressed (USA, northern Mexico) . . . . . . ................ L. cupreopunctata (Schaeffer, 1905)

- Dorsal coloration shining black with brassy tinge; ventral surface shining black with purple tinge; punctures and impressions brassy; pronotum constricted near posterior margin; elytral disc with slightly impressed punctate striae, four striae visible at anterior margin (Mexico) .......... L. obscura Thomson, 1879

12 Elytra with clearly visible, large impressions along lateral margins, such as in Figs $78,79 \ldots \ldots \ldots \ldots \ldots$

- Elytra without that characteristic, only with few or numerous interstrial impressions. . . . . . . . . . 14

13 Pronotum black with punctures aeneous margined with bright green, lateral margins slightly concave before posterior margin, expanded at middle, and rounded toward anterior angles; elytral surface dark brown with purple tinge, lateral margin with six or eight large brassy-green, bright green or cupreous impressions, or ten small impressions, the size of the impressions diminishing toward apices, these impressions are formed by numerous small, confluent punctures; apices with purple or bluish-green tinge (Mexico, USA). . . . . . ..... L. auropunctata (Kerremans, 1893)

- Pronotum dark bronze with metallic reddish tinge, along anterior margin to midline with a slight depression; elytra dark bronze with pink and brassy-green tinge, with four transverse impressions extending from lateral margin to middle, the last one smaller than the others; ventral surface metallic red with dark bronze tinge; punctures and impressions bright green (Panama, Venezuela).

L. hirtomaculata (Herbst, 1801)

4 Elytral surface with groups of interstrial punctures sur-

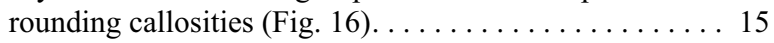

- Elytral surface without callosities (Figs 5, 18, 22) . . . . . 16

15 Elytral surface with sparse confluent punctures at middle. 17

- Elytral surface with abundant confluent punctures at middle. 
16 Elytral surface with two colors, red-coppery from the suture to the fourth striae, bright green toward lateral margin; apices bright green with blue tinge; ventral surface bright red-coppery; pronotal lateral margins slightly concave, expanded at middle, then obliquely converging to lateroanterior angles (Guatemala, Mexico).

$$
\text { L. chalconota (Waterhouse, 1882) }
$$

Elytral surface without previous combination of characteristics. . . . . . . . . . . . . . . . . . . . . . . 19

17 Dorsal surface bright green with reddish tinge medially and laterally, punctures bright green margined with blue or violet; ventral surface red-coppery medially, bright green with reddish and brassy tinge laterally, punctures bright green; pronotal lateral margins subparallel before base, slightly expanded at middle and obliquely converging to anterior angles (Mexico) ................. L. cyanitarsis sp. n. Dorsal surface greenish and bluish black; ventral surface red-coppery with brassy tinge; punctures cupreous margined with red-coppery; pronotum along lateral margins and anterior margin toward middle each with a slight depression, both impressions converge; surface with impunctate areas, and large, deep, sparse punctures (Guatemala, Honduras, Mexico).............. Leniculata (Waterhouse, 1889)

18 Dorsal and ventral surfaces bright green laterally, bright green with reddish and yellowish tinge medially; punctures and impressions bright green; pronotum slightly flattened in midline toward base; elytral disc with strongly impressed punctate striae and after the second striae with many finely punctate interstrial impressions (Brazil, Guatemala, Mexico). . . . . . . . . . . L . granulifera (Laporte \& Gory, 1837) violet tinge, disc with slightly impressed punctate striae, first three striae clearly visible; apices dark bluish-green with violet tinge; ventral surface metallic green medially, bluish-green laterally; dorsal and ventral punctures metallic green (Mexico). . . . . . . . . . L. mexicana Théry, 1923

19 Dorsal surface lead-green with dark blue tinge; ventral surface lead-green, with dark blue and purple tinge; dorsal and ventral punctures purple; pronotal surface irregularly punctate, with abundant large, deep, confluent punctures, premarginal area with vague longitudinal depression formed by confluent punctures laterally; elytral surface with strongly impressed punctate striae; along lateral margin with narrow, longitudinal depression (Costa Rica). Ventral surface bright green medially, red-coppery laterally; dorsal and ventral punctures and impressions bright green; pronotum bright green; elytra bright green with reddish tinge medially, with strongly impressed punctate striae, generally after fourth striae to lateral margins with few finely punctate, interstrial impressions (Costa Rica, Guatemala, Honduras, Mexico). . . . . . . . L. monilis (Chevrolat, 1834)

20 Prosternal process with punctures at middle; dorsal surface bluish-green, sometimes dark-green, impressions blue, green or violet; ventral surface dark green or bluish-green, some punctures blue; pronotal lateral margins subparallel at base, slightly expanded before base, then obliquely converging to anterior angles (Grenada, Grenadines). . . . . . . . . . . . .

\section{L. guildini (Laporte \& Gory, 1836)} Prosternal process without punctures at middle ...... 21

21 Head with frontovertex sinuate, when viewed from above (Fig. 71) . . . . . . . . . . . . . . . . . . . . 22

- Head with frontovertex flattened, when viewed from above (Fig. 72) .......................... 23

22 Frons with abundant confluent punctures (Fig. 71). . . . 24

- Frons with few confluent punctures (Fig. 72)....... 25
23 Elytral apices with angles usually not produced (Fig. 76). 26

- Elytral apices obliquely truncate with angles variously produced (Fig. 77) . . . . . . . . . . . . . . 27

24 Body slender; ventral surface purple with greenish tinge; dorsal and ventral punctures dark green with bright green marginally; pronotum purple with greenish tinge, flattened in midline toward base and with strong, broad depression at midline near posterior margin; elytra bright green with reliefs purple medially and purple and bluish green laterally, apices purple (Mexico) . . . . . . . . . . . L. tigrina sp. n.

- Body moderately robust; dorsal surface dark green with bluish and violet tinge, impressions bright green, punctures bright green margined with blue; ventral surface bright green medially, bright green with brassy-green and reddish tinge laterally, punctures bright green; elytral disc with slightly impressed punctate striae, surface with few small, finely punctate, interstrial non-confluent impressions (Honduras, Mexico)............... L. viridicolor sp. $\mathrm{n}$.

25 Dorsal surface black; ventral surface bright red medially, black with red tinge laterally; dorsal and ventral punctures cupreous margined with red; pronotal surface with numerous small, deep, sparse punctures medially; elytral disc with strongly impressed punctate striae, sixth interval with few small punctures, becoming deeper, more numerous laterally, surrounding a few indistinct callosities toward lateral margins (Costa Rica, El Salvador, Honduras, Mexico, Nicaragua). . . . . . . . . . L. simplex (Waterhouse, 1882)

- Entire surface reddish brown with golden green tinge; frontovertex with ocular depression along inner margin of eyes; pronotum slightly flattened in midline toward posterior margin; pronotum and elytra with premarginal impressions laterally, these impressions formed by abundant small, deep, very confluent punctures; first and second ventrites slightly concave along midline (Costa Rica)...... . ................. L. srdinkoana (Obenberger, 1924)

26 Ventral surface metallic red with greenish and brassy tinge, punctures bright green; dorsal punctures bright green margined with dark green; pronotum metallic red medially, metallic red with greenish tinge laterally; elytra metallic red medially, bright green laterally, apices reddish, disc with slightly impressed punctate striae, and with sparse, small, finely punctate, interstrial impressions; tarsi metallic red with purple and green tinge (Guatemala, Honduras) ....... $\ldots \ldots \ldots \ldots \ldots \ldots \ldots$ L. viridimarginalis $\mathrm{sp} . \mathrm{n}$.

- Dorsal and ventral surfaces dark brown with olive-green tinge medially, purple tinge laterally; dorsal punctures olive green margined with purple; ventral punctures and impressions purple; pronotal disc flattened in midline toward posterior margin with sparse punctures; elytral disc slightly convex, surface with slightly impressed punctate striae, first three striae clearly visible, and with many finely punctate, small interstrial impressions (Mexico, Nicaragua).

$$
\text { L. christophi Théry, } 1923
$$

27 Elytral apices with outer angle produced and sutural angle not or slightly produced, ventral surface red-cupreous; punctures and impressions aeneocupreous; pronotum black with reddish tinge; elytra black, four striae visible, surface with many finely punctate, interstrial impressions, commonly confluent in transverse groupings, with few small callosities laterally; processus intercoxalis of the first ventrite slightly concave at middle, ventrite 2 slightly concave at anterior margin (Honduras, Mexico). . . . . . . . . .

$$
\text { L. cortesi (Laporte \& Gory, 1837) }
$$

Elytral apices with outer and sutural angles produced... . 28 
28 Elytra usually with 7-9 small impressions along lateral margins, the impressions more numerous and larger than interstrial impressions medially; entire surface dark brown with bronze and purplish tinge; punctures brassy margined with purple; scutellum rounded; processus intercoxalis of the first ventrite slightly concave at middle, ventrite 2 flattened (Honduras)................... L. hondurensis sp. n.

- Elytra with slightly impressed punctate striae, without impressions along lateral margins; scutellum transversely oval . . . . . . . . . . . . . . . . . . . . . . . . . 29

29 Elytral surface with punctate interstrial impressions, commonly confluent in transverse groupings; dorsal and ventral surfaces metallic red with punctures bright green; elytral margins and apices bright green; prosternum bright green with reddish tinge; tarsi bright dark blue; ventrites metallic red with olive green tinge; first ventrite with median longitudinal depression bordered on either side by smooth carina (Mexico)................. L. chiapaneca Corona, 2004 Elytral surface with punctate interstrial impressions, commonly isolated from each other. . . . . . . . . . 30

30 Dorsal surface metallic red with brassy green tinge; ventral surface metallic red; dorsal and ventral punctures and impressions bright green; pronotal disc slightly flattened; scutellum metallic red with bright green tinge; tarsi metallic red with bluish and greenish tinge; processus intercoxalis of the first ventrite slightly concave at middle, ventrite 2 flattened along midline (Mexico).......... L. chamela $\mathrm{sp} . \mathrm{n}$.

- Dorsal and ventral surfaces black with reddish tinge, punctures and impressions cupreous; elytral disc moderately convex with slightly impressed punctate striae, four striae visible, surface with many small interstrial impressions; processus intercoxalis of the first ventrite weakly concave at middle; second ventrite flattened at midline (Mexico) . . . . . . .............................. L. colima sp. n.

\section{Lampetis (Spinthoptera) aurata (Saunders, 1871)}

(Figs 1, 32, 62)

Buprestis aurifera Laporte \& Gory, 1837 (preoccupied name: Fabricius, 1801).

Psiloptera aurata Saunders, 1871: 23; Kerremans, 1885: 132; 1892: 57; 1903: 93; 1910: 56.

Psiloptera (Lampetis) aurata; Fisher, 1925: 56; Obenberger, 1926: 163; 1934: 54; Blackwelder, 1944: 310.

Psiloptera aurata var. domingoensis Fisher, 1930: 126.

Lampetis (Spinthoptera) aurata; Kurosawa, 1993: 580.

Diagnosis. Punctures and impressions golden-green, with short, recumbent, white setae; pronotum black with slight bluish and purplish tinge, surface with impressed median furrow with numerous fine, confluent punctures, along lateral margins and anterior margin near border with a depression formed by abundant small, deep, confluent punctures, depression with few small callosities; elytra reddish dark brown, sometimes red-coppery at sides, punctures cupreous, some callosities with blue or violet tinge; prosternum black with green or purple tinge; metasternal and abdominal surface black with green and purple tinge; abdomen with first ventrite broadly and largely concave along midline; ventrite 2 slightly concave along midline.

Male redescription. Length $19.8-21.5 \mathrm{~mm}$; width 7.4-8.0 mm. Head: Labrum dark green, with abundant shallow, confluent punctures, with numerous setae; clypeus dark green with golden-green tinge, with scarce small, deep punctures along anterior margin; frons flattened with numerous small, deep, confluent punctures and frontal callosities dark-green; these punctures forming numerous and large callosities; along margin of the eyes with abundant setae; vertex surface black with dark green and purple tinge; with few small punctures; mandibles blue with violet tinge; with numerous small, deep, confluent punctures, punctures bright green or blue; maxillary palp blue with violet tinge; antennal segment 1 bright green, rest of segments black. Pronotum: 1.6 times wider than long; lateral margins slightly concave near base, slightly expanded at middle and rounded to anterior angles, slightly narrowed apically; lateral margins discontinuously carinate at base toward middle; anterior and posterior margins bisinuate, each with a median lobe; posterior angles acute; disc convex; surface with impunctate areas extensive, these areas with green and violet tinge. Scutellum: large, black with greenish, bluish or purplish tinge, transversely oval. Elytra: apices oblique and weakly emarginate; outer and sutural angles weakly dentiform; disc convex, with strongly impressed punctate striae, five striae visible; striae with small, deep punctures, with abundant setae; surface transversely impressed basally, and many groups of few small, deep punctures between striae; along lateral margins with small callosities and bright green tinge. Prosternum: disc moderately convex; with numerous small, deep, not confluent punctures laterally; without punctures at midline; prosternal process strong purple, slightly convex, apex bluntly rounded. Mesosternum: divided, surface without punctures medially, but with small, deep, confluent punctures laterally. Mesepimeron and mesepisternum: strong purple; surface with abundant small, shallow, not confluent punctures. Metasternum: surface flattened, finely punctate and clothed with fine setae medially; laterally with abundant small, shallow, very confluent punctures. Metacoxae: surface golden-green with red-coppery tinge; external lateral margin to middle rugosely punctate with abundant small, deep, confluent punctures; toward internal lateral margin with scarce small, shallow punctures; along posterior margin to middle with fine, shallow, confluent punctures. Femora: strong purple with dark-green tinge at sides, punctures golden-green; with small, shallow, sparse punctures. Tibiae: strong purple with blue tinge at sides, punctures dark-green; surface with abundant small, shallow, confluent punctures, with abundant setae. Tarsi: blue and violet. Abdomen: first ventrite concave along midline, wide and large concavity, with few fine punctures bordered by impunctate carina; ventrite 2 slightly concave along midline; ventrites 3-5 convex; apex of last visible ventrite feebly rounded, with weak emargination at middle; abdominal surface densely punctate, with abundant small, shallow, confluent punctures, and with impunctate areas. Male genitalia as in Fig. 32 .

Female. Length 17.2-26.3 mm; width 6.5-10.4 mm.

Variation. The 33 males and 33 females examined revealed that some of the specimens collected on Boca Chica, Dominican Republic differ from the rest as 

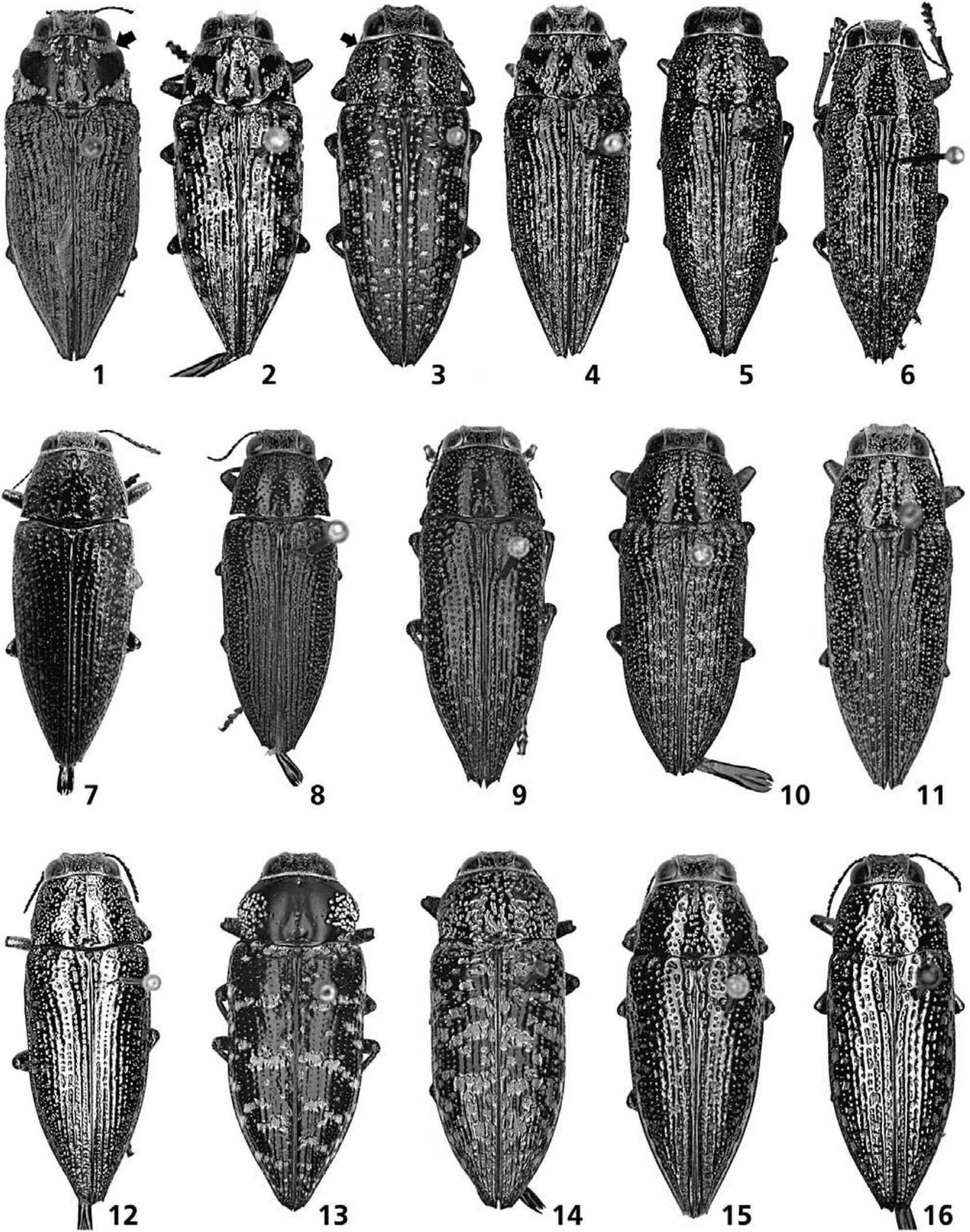

Figs 1-16: Male dorsal habitus: 1 - Lampetis (Spinthoptera) aurata (Saunders, 1871); 2 - L. aurifera (Olivier, 1790); 3 - L. auropunctata (Kerremans, 1893); 4 - L. bahamica (Fisher, 1925); 5 - L. chalconota (Waterhouse, 1882); 6 - L. chamela $\mathrm{sp.} \mathrm{n} . ; 7$ - L. chiapaneca Corona, 2004; 8 - L. christophi Théry, 1923; 9 - L. colima sp. n.; 10 - L. cortesi (Laporte \& Gory, 1837); 11 - L. cupreopunctata (Schaeffer, 1905); 12 - L. cyanitarsis sp. n.; 13 - L. dilaticollis (Waterhouse, 1882); 14 - L. drummondi (Laporte \& Gory, 1836); 15 - L. geniculata (Waterhouse, 1889); 16 - L. granulifera (Laporte \& Gory, 1837). 
follows: striae of elytra feebly impressed, formed by large and not confluent punctures, and with numerous finely punctate, reddish-cupreous interstrial impressions, these commonly confluent in transverse and oblique groupings and densely clothed with recumbent, yellowish setae, laterally the striae more confluent forming numerous callosities; along lateral margins with reddish-cupreous color.

Differential diagnosis. Lampetis aurata is closely related to L. aurifera Olivier. Lampetis aurifera dorsal surface is dark green, sometimes with purplish tinge; ventral surface strong purple with dark-green and goldengreen tinge, punctures golden-green; longitudinal median depression of pronotum feebly interrupted in front of middle, and with transversely oblique depression; elytra with many transverse irregular golden-green interstrial impressions.

Type material studied. Buprestis aurifera: Female holotype: [Aurifera/ Fabr./ s. Domingue Type Gory] (MNHN). Psiloptera aurata var. domingoensis: Female holotype: [Romana/ SDomingo] [H.E.Box/July, 25] [Type No./ 43132/ U.S.N.M.] [Psiloptera/ var. Domingoensis/ Fisher] (USNM).

Distribution. This species has been found in Dominican Republic as follows: Distrito Nacional: Boca Chica; La Altagracia: Guaraguao; La Vega: 10 km W Jima; Monte Cristi: Carbonera, 8.2 km N Villa Elisa, 2.9 km N Villa García; San Cristóbal: San Cristóbal; Santiago de los Caballeros; Santiago Rodríguez: Gurabo, Sabaneta; Santo Domingo; Valverde: Potrero; Valverde. In Haiti as follows: Nord-Ouest: Cayenne; Port-auPrince.

Phenology. Collected from March to October.

\section{Lampetis (Spinthoptera) aurifera (Olivier, 1790)}

(Figs 2, 33, 63)

Buprestis aurifer Olivier, 1790: 13; Herbst, 1801: 185.

Buprestis aurifera Fabricius, 1801: 191; Schönherr, 1817: 219; Laporte \& Gory, 1836: 35; Jacquelin du Val, 1857: 58.

Buprestis amethystipes Laporte \& Gory, 1836: 37; Gemminger \& Harold, 1869: 1364; Saunders, 1871: 23; Kerremans, 1892:

57; 1903: 93; 1910: 57; Fisher, 1925: 54; Obenberger, 1926: 164; Blackwelder, 1944: 310.

Psiloptera wurtembergi Mannerheim, 1837: 49; Gemminger \& Harold, 1869: 1369; Saunders, 1871: 23; Kerremans, 1892: 66; 1903: 93; 1910: 57; Fisher, 1925: 54; Obenberger, 1926: 164; Blackwelder, 1944: 310; Nelson, 1976: 167.

Psiloptera aurifera; Chevrolat, 1867: 575; Gemminger \& Harold, 1869: 1364; Gundlach, 1891: 158 .

Psiloptera aurifer; Saunders, 1871: 23; Kerremans, 1892: 57; 1903: 93; 1910: 57.

Psiloptera (Lampetis) aurifer; Fisher, 1925: 54; Blackwelder, 1944: 310; Obenberger, 1926: 164; Théry, 1927: 254.

Lampetis (Spinthoptera) aurifer; Kurosawa, 1993: 580.

Diagnosis. Dorsal surface dark green, sometimes with purplish tinge; ventral surface strong purple with darkgreen and golden-green tinge; impressions and punctures golden-green; impressions are also usually covered with a pale yellow pulverulence; punctures with short, white setae; pronotal surface with a longitudinal median depression, broader posteriorly and feebly interrupted at middle, a broad depression on each side along anterior margin, another narrow depression along lateral margins but not reaching to the posterior angles, and a transversely oblique depression behind the middle on both sides, these impressions coarsely and densely punctate; abdomen with first ventrite slightly concave along midline, ventrite 2 flattened in midline.

Male redescription. Length $16.0-22.2 \mathrm{~mm}$; width 5.5-8.6 mm. Head with short, semierect, white setae. Labrum golden-green, sometimes with dark green areas, with numerous small, shallow, confluent punctures; clypeus dark green with golden-green areas, anterior margin slightly concave and with few small, deep, confluent punctures along anterior margin; frons flat, dark green with golden-green tinge, surface with numerous small, deep, confluent punctures with few large, strong callosities, along margin of the eyes with abundant fine, confluent punctures, with abundant setae; vertex dark green; bases of mandibles golden-green, with few large, deep, not confluent punctures, with few setae; maxillary palp blue with violet tinge; first antennal segment darkgreen, the rest dark-brown with golden-green tinge. Pronotum: dark green, with strong purplish tinge; 1.6 times wider than long, widest at base; lateral margins slightly concave before base, weakly expanded at middle, then obliquely converging to anterior angles; narrowest anteriorly; lateral margins slightly carinate at middle to base; anterior margin slightly bisinuate with weak median lobe; posterior margin slightly bisinuate with broad median lobe; posterior angles acute; disc moderately convex; areas without impressions finely granulose with scarce punctures. Scutellum: dark green with strong purplish tinge, transversely oval, slightly depressed at middle and surface finely granulose. Elytra: dark green with strong purple tinge; apices obliquely and slightly emarginate, outer and sutural angles weakly dentiform; disc moderately convex with weakly impressed punctate striae, with fine, not confluent punctures; surface with many small impressions along base and many transverse irregular interstrial impressions, these with numerous fine punctures, usually isolated from each other, and densely clothed with setae; laterally with slight callosities. Prosternum: strong purple with dark-green tinge, anterior margin slightly concave, disc moderately convex, surface with few small, deep, punctures laterally, some in groups of two o three, without punctures medially, along anterior margin with abundant small, deep, confluent punctures; prosternal process strong purple with dark-green tinge; slightly convex; sulci with abundant fine, deep, confluent punctures; apex bluntly rounded. Mesosternum: strong purple and dark-green, divided, surface with numerous small, deep, confluent punctures laterally, without punctures medially. Mesepisternum and mesepimeron: with numerous small, shallow, not confluent punctures, with abundant setae, and with impunctate areas; both strong purple with dark-green and golden-green tinge. Metasternum: strong purple with dark-green, punctures goldengreen margined with dark-green; flattened with scarce small, shallow punctures medially; laterally with abundant small, deep, confluent punctures. Metacoxae: strong purple with some dark-green areas; surface with numerous large, deep, confluent punctures at middle 

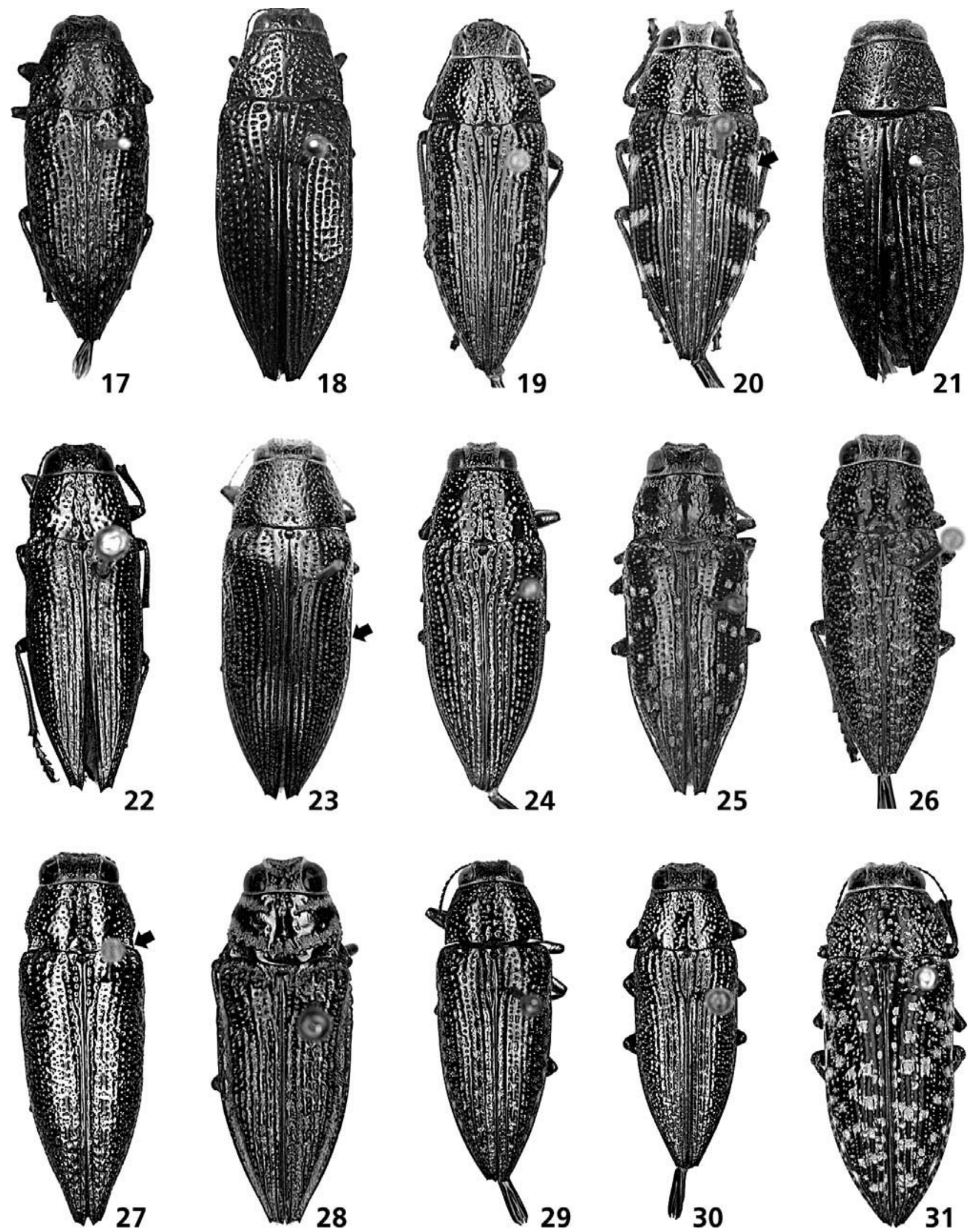

Figs 17-31: Male dorsal habitus: 17 - Lampetis (Spinthoptera) guildini (Laporte \& Gory, 1836); Female dorsal habitus: 18 - L. lesnei (Kerremans, 1910); Male dorsal habitus: 19 - L. hondurensis sp. n.; 20 - L. hirtomaculata (Herbst, 1801); Female dorsal habitus: 21 - L. mexicana Théry, 1923; Male dorsal habitus: 22 - L. monilis (Chevrolat, 1834); 23 - L. simplex (Waterhouse, 1882); 24 L. srdinkoana (Obenberger, 1924); 25 - L. straba (Chevrolat, 1867); 26 - L. obscura Thomson, 1879; 27 - L. tigrina sp. n.; 28 - L. torquata (Dalman, 1823); 29 - L. viridicolor sp. n.; 30 - L. viridimarginalis sp. n.; 31 - L. webbii (LeConte, 1858b). 
toward external lateral margin; along border of posterior margin with abundant small, deep, confluent punctures, with abundant setae; scarce small, deep punctures at internal lateral margin; along border of internal lateral margin with numerous small, deep, confluent punctures. Femora: strong purple with some dark-green tinge at sides, punctures dark-green; with numerous small, deep, punctures, surface with some impunctate areas. Tibiae: strong purple, punctures dark-green margined with blue; surface with numerous small, shallow, not confluent punctures, with fine setae. Tarsi: violet with some blue areas. Abdomen: strong purple with dark-green and golden-green tinge; with first ventrite slightly concave along midline, this concavity with numerous small, shallow, confluent punctures, and bordered by slight impunctate carina; ventrite 2 flattened in midline; ventrites 3-5 convex; apex of last visible ventrite subtruncate and feebly sinuate at middle; abdominal surface sparsely and irregularly punctate. Male genitalia as in figure 33 .

Female. Length 18.1-26.8 mm; width 7.0-10.5 mm.

Variation. This species (32 males and 38 females examined) varies in the coloration; dorsal surface with the usual bright green with purple tinge to purple with bright green tinge; elytra from bright green to yellowish-green at middle.

Differential diagnosis. Lampetis aurifera is closely related to L. aurata and L. torquata. Lampetis aurata is bluish black with strong greenish or violaceous tinge below; pronotum black with a slight bluish tinge, without transversely oblique depression behind the middle; scutellum black with greenish and bluish tinge; elytra reddish dark brown with bluish and purplish tinge, sometimes red-coppery at sides, punctures cupreous, some callosities with blue or violet tinge. Lampetis torquata is olive green at middle, becoming purplish toward the sides; pronotum with two arcuate impressions, one along the anterior margin, the other near the base; scutellum bronzy-green; elytra with a longitudinal groove along the lateral margins, reliefs dark green and impressions bronzy-green margined with purple.

Type material studied. Buprestis amethystipes: Female holotype: [Amellyistipes/ Gory/ wurternbergi/ Dej./ s. Domingue/ Types] (MNHN). Psiloptera wurtembergi: Female lectotype: [Hummel.] [St. Domingo] [LECTOTYPE/ Psiloptera/ wurtembergii/ Det. Mannerheim/ G.H. Nelson] [Mus. Zool. Hifors/ Spec. typ. No. 15179/ Psiloptera/ wurtembergii Mannh. 1337/ design. Volkovitsh 05. 993] (ZMUC).

Distribution. This species has been collected in Cuba, Dominican Republic, and Haiti. Province, Department or county records include the following: in Dominican Republic: Azua: Azua de Compostela; Barahona: $4.5 \mathrm{~km} \mathrm{~S}$ Barahona, $11 \mathrm{~km} \mathrm{~S}$ Barahona; Pedernales: Larimar Mine, P.N. Jaragua, $12.2 \mathrm{~km} \mathrm{~N}$ Oviedo; Peravia: 13 km W Bani, Cueva Jimagosa, 6 km SE Pedernales, 6 km NW Cabo Rojo Rd.; San Juan: Sabana Alta; Santo Domingo. In Haiti: Ouest: Petionville; Port-au-Prince; Artibonite: Santiago.

Adult host plants. On Acacia lutea, Prosopis juliflora (Fabaceae), Piper nigrum (Piperaceae), and flowers of tropical almond.

Phenology. Collected from May to December.

\section{Lampetis (Spinthoptera) auropunctata (Kerremans, 1893)}

(Figs 3, 34, 69)

Psiloptera (Lampetis) auropunctata Kerremans, 1893: 507; 11903: 94; 1910: 156; Obenberger, 1926: 164; Blackwelder, 1944: 310; Westcott et al., 1990: 230.

Lampetis (Spinthoptera) auropunctata; Kurosawa, 1993: 580.

Diagnosis. Head cupreous with brassy, bright or dark green tinge; punctures with short, recumbent, white setae; impressions brassy-green; ventral surface with punctures bright green; antennae black with blue, green and violet tinge; pronotum black with punctures brassy margined with bright green, flattened in midline toward base; elytra dark brown, disc with feebly impressed punctate striae, along lateral margin with ten or more small, deep, brassygreen impressions with abundant fine setae, the size of impressions diminishing toward apex, apices with purple or bluish green tinge; first ventrite concave along midline emarginate by blunt impunctate carina.

Female holotype redescription. Total body length $30.4 \mathrm{~mm}$, width $10.8 \mathrm{~mm}$. Head: Labrum brassy with cupreous and dark green tinge at midline and with abundant shallow punctures, and abundant setae; clypeus black, with brassy and dark green tinge, anterior margin concave, with abundant shallow, brassy punctures laterally, without punctures medially; frons black, callosities black with violet and dark green tinge, flattened, with abundant small, deep, confluent and bright green punctures, with many small callosities; vertex surface black, punctures dark green and violet; mandibles with violet and dark green tinge basally, with few small, deep, brassy punctures, becoming denser and confluent toward apex. Pronotum: 1.7 times wider than long, widest at middle; lateral margins concave before base, expanded at middle, and rounded to anterior angles, lateral margins slightly carinate; anterior and posterior margins slightly bisinuate, each with weak median lobe, posterior angles slightly acute; disc moderately convex, flattened in midline toward base; along anterior margin with a bead-like depression from lateral margin to midline; surface with few small, deep and confluent punctures forming groups, with some impunctate areas medially, more numerous and confluent punctures laterally with numerous small callosities. Scutellum: black, oval. Elytra: apices with purple or bluish green tinge, slightly oblique and weakly emarginate, outer and sutural angles not dentiform; disc convex, with feebly impressed punctate striae, punctures fine, shallow, not confluent, surface with few impressions basally and few small, interstrial impressions formed with fine punctures, isolated from each other and scarcely clothed with setae; along lateral margins with ten or more, small, deep impressions with abundant fine setae, the size of impressions diminishing toward apex; punctures bright green margined with purplish along lateral margins. Prosternum: surface red-coppery, with bright green tinge; disc convex, densely punctate laterally; with few small, deep punctures medially, more confluent punctures along anterior margin; prosternal process: red-coppery, with bright green tinge; flattened; apex bluntly rounded. Mesoster- 

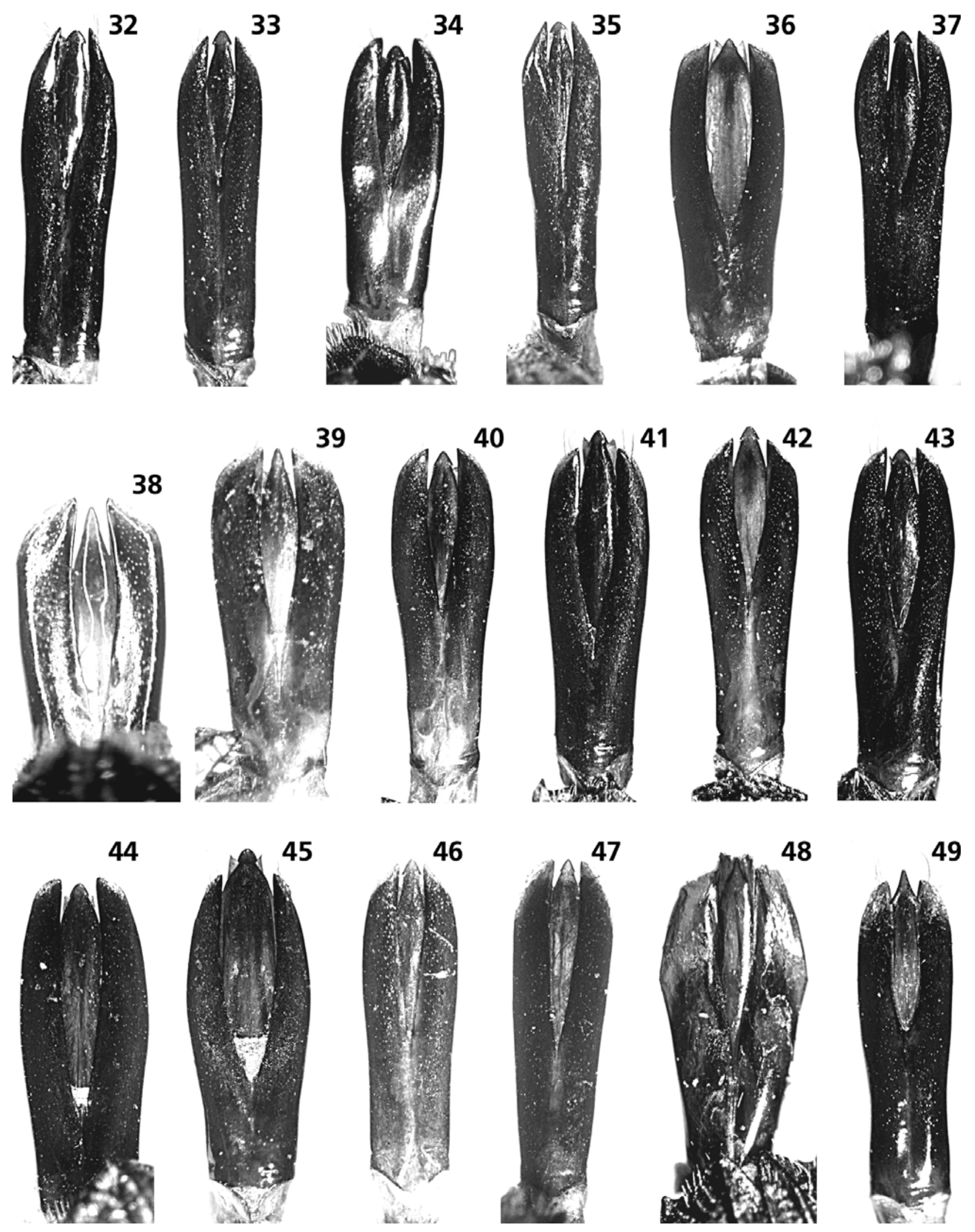

Figs 32-49: Male genitalia, dorsal aspect: 32 - Lampetis (Spinthoptera) aurata (Saunders, 1871); 33 - L. aurifera (Olivier, 1790); 34 - L. auropunctata (Kerremans, 1893); 35 - L. bahamica (Fisher, 1925); 36 - L. chalconota (Waterhouse, 1882); 37 - L. chamela sp.n.; 38 - L. chiapaneca Corona, 2004; 39 - L. christophi Théry, 1923; 40 - L. colima sp. n.; 41 - L. cortesi (Laporte \& Gory, 1837); 42 - L. cupreopunctata (Schaeffer, 1905); 43 - L. cyanitarsis sp. n.; 44 - L. dilaticollis (Waterhouse, 1882); $45-L$. drummondi (Laporte \& Gory, 1836); 46 - L. geniculata (Waterhouse, 1889); 47 - L. granulifera (Laporte \& Gory, 1837); 48 - L. guildini (Laporte \& Gory, 1836); $49-$ L. hirtomaculata (Herbst, 1801). 
num: surface red-coppery; divided, without punctures medially, but with numerous small, deep, confluent punctures laterally. Mesepisternum and mesepimeron: redcoppery with greenish and purplish tinge, with few small, shallow, sparse punctures. Metasternum: surface redcoppery, reliefs black, with green and purple tinge; surface flattened medially with few fine, sparse punctures medially; abundant small, deep, confluent punctures laterally. Metacoxae: red-coppery, reliefs black with green and purple tinge; along basal margin toward middle with abundant small, deep, confluent punctures; toward external lateral margin with few small, deep, sparse punctures; medially with abundant small, deep, confluent punctures and posterior margin with smaller and confluent punctures; internal lateral margin with scarce small, fine, sparse punctures. Femora: surface black with green and violet tinge, with numerous small, deep punctures; punctures brassy-green or bright green. Tibiae: surface black with purple and green tinge, with more abundant small, confluent punctures than punctures of femora; punctures blue. Tarsi: black with violet and blue tinge. Abdomen: surface red-coppery, reliefs black with green and purple tinge; first ventrite concave along midline, concavity is wide, with few small, shallow punctures and bordered by impunctate carina; other ventrites convex; apex of last visible ventrite rounded; abdominal surface with abundant small, shallow, confluent, irregular punctures.

Male. Length 21.0-27.8 mm; width 7.4-10.0 mm. Differs from female as follows: antenna with segments 6-11 serrate, each truncate on toothed border; apex of last visible ventrite feebly rounded with weak emargination at middle. Male genitalia as in Fig. 34.

Variation. Total body female length $22.5-31.7 \mathrm{~mm}$; width $7.8-12.2 \mathrm{~mm}$. This species (26 males and 39 females examined) varies in the number, size and shape of depression along lateral margins as follow: from ten or more small, deep impressions to six or eight large, deep impressions, the first of these near basal margin larger than the others, the size of the rest is diminishing toward apex, these impressions rounded to oval; scutellum oval to rounded; punctures and impressions from brassy-green or bright green to cupreous; clypeus black to cupreous; callosities of the frons and vertex black with violet and dark green tinge to black with purplish, bluish, greenish and brassy tinge; base of mandibles with violet and dark green tinge, sometimes with cupreous and blue tinge; pronotum from black to bluish black, some specimens with some purplish tinge; scutellum black to black with greenish or reddish tinge; elytra from dark brown to dark brown with some purplish and greenish tinge; prosternum red-coppery, with bright green tinge to red-coppery with greenish tinge medially, bright green with brassy and reddish tinge laterally; mesosternum red-coppery to redcoppery with brassy tinge; femora from balck with green and violet tinge to purple with greenish and bluish tinge or red-coppery with green and blue tinge; tarsi black with violet and blue tinge to black with violet and green tinge.
Differential diagnosis. Lampetis auropunctata is similar to L. webbii. Lampetis webbii is robust; dorsal surface dark bluish-black, punctures brassy-green; ventral surface dark blue; elytral apices generally dark blue; pronotum with lateral margins obliquely converging anteriorly; elytral disc with punctate interstrial impressions usually isolated from each other, striae feebly impressed, without impressions along lateral margins; first ventrite concave along midline usually emarginate by smooth, broad carina.

Type material studied. Female holotype: [HOLO-/TYPE] [Mexique/ Heyne] [auropunctata/ Kerr./ Type] (BMNH).

Distribution. This species is found in the USA (new record) from Arizona: Tucson and Texas: Brownsville, and in Mexico: Aguascalientes: $18 \mathrm{~km} \mathrm{~W}$ Aguascalientes; Chihuahua: Temoris, 2 mi N Temoris; Durango: Ventanas; Jalisco: N Ajijic, $20 \mathrm{~km} \mathrm{~N}$ Autlán; Hwy. 80, 7.3 mi S Cocula; 14 km SW Cocula, Chapala, Guadalajara; Cerro García at $32 \mathrm{mi} \mathrm{S}$ Guadalajara; $19 \mathrm{mi} \mathrm{S}$ Guadalajara; Huejotitan; La Huerta; NW Villa Hidalgo; 18 km NW Los Volcanes; 20.9 km N St. Gabriel; 15 km NE St. Gabriel; Nayarit: San Blas, Vol. Ceboruco.

Adult host plants. On Compositae, Acacia sp. and Mimosa sp. (Fabaceae), and Sida sp. (Malvaceae).

Phenology. Collected from June to December.

\section{Lampetis (Spinthoptera) bahamica (Fisher, 1925)}

(Figs 4, 35, 64)

Gyascutus carolinensis: Wickham, 1895: 295 (misidentification); Fisher, 1925: 60 (syn. of bahamica).

Psiloptera (Lampetis) bahamica Fisher, 1925: 60; Obenberger, 1926: 164; Théry, 1927: 254; Blackwelder, 1944: 310; Cazier, 1951a: 6.

Lampetis (Spinthoptera) bahamica; Kurosawa, 1993: 580.

Diagnosis. Punctures with short, recumbent, white setae; head dark brown with cupreous tinge, impressions and punctures olive-green; pronotum and elytra with shining, bluish, purplish, cupreous tinge at light; ventral surface dark brown with cupreous and blue tinge, punctures olive-green; pronotal impressions olive-green or red-coppery; elytral disc convex with weakly impressed punctate striae, with many interstrial impressions, usually isolated from each other; abdomen with first ventrite weakly concave along midline, this concavity not bordered by carina, other ventrites convex.

Male redescription. Length 15.4-23.1 mm; width 5.2-8.5 mm. Head: Labrum with numerous small, shallow, confluent punctures, surface granulose; clypeus anterior margin concave with few small, deep, confluent punctures, without punctures medially; frons slightly sinuate, surface with abundant small, deep, confluent punctures, with many strong callosities, punctures with larger setae than labrum, along margin of the eyes with abundant small, deep, confluent punctures and with abundant setae; vertex with few small, shallow, sparse punctures; bases of mandibles cupreous with blue tinge, rugosely punctate, with abundant small, deep, confluent punctures, with abundant setae; maxillary palpi cupreous, sometimes with blue tinge, with abundant setae; first antennal segment cupreous, the rest dark brown with redcoppery and blue tinge. Pronotum: 1.6 times wider than long, widest at middle; lateral margins subparallel at base, 

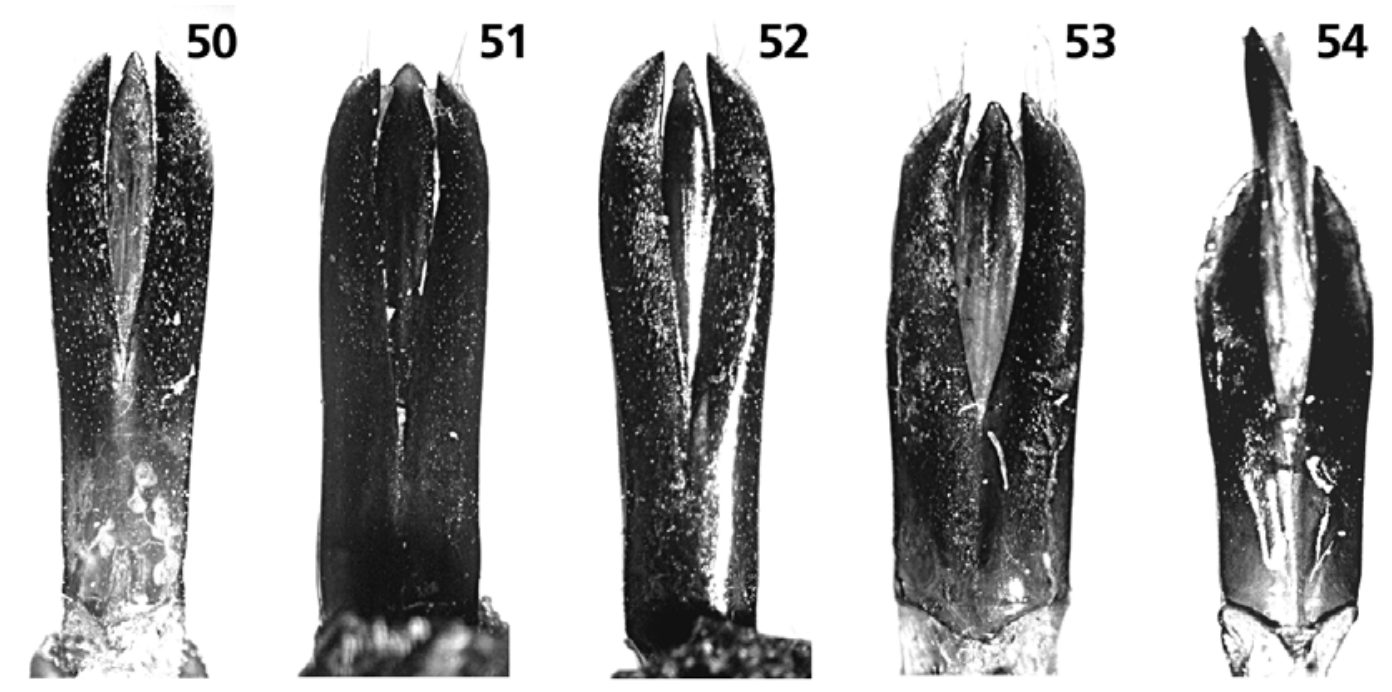

55
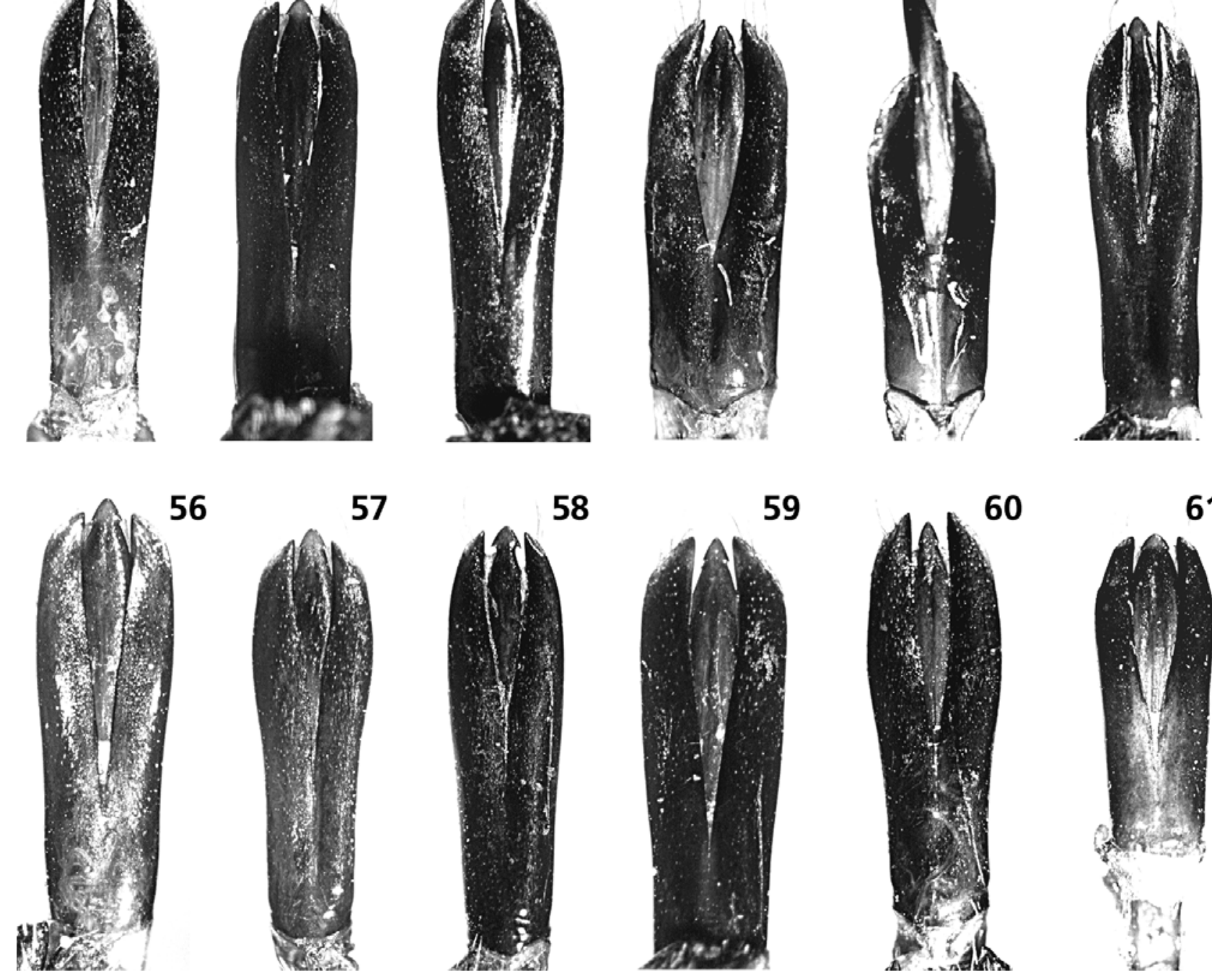

Figs 50-61: Male genitalia, dorsal aspect: 50 - Lampetis (Spinthoptera) hondurensis sp. n.; 51 - L. mexicana Théry, $1923 ; 52$ - L. monilis (Chevrolat, 1834); 53 - L. simplex (Waterhouse, 1882); 54 - L. srdinkoana (Obenberger, 1924); 55 - L. straba (Chevrolat, 1867); 56 - L. obscura Thomson, 1879; 57 - L. tigrina sp. n.; 58 - L. torquata (Dalman, 1823); 59 - L. viridicolor sp. n.; 60 - L. viridimarginalis sp. n.; 61 - L. webbii (LeConte, 1858).

slightly expanded at middle and rounded toward anterior angles; narrowest anteriorly; lateral margins carinate at middle to posterior margin; anterior margin slightly bisinuate with weak median lobe; posterior margin slightly bisinuate with broad median lobe; posterior angles acute; disc moderately convex, slightly flattened in midline toward base, surface with two slight transverse arcuate impressions formed by numerous small, deep, confluent punctures, the impressions are interrupted at middle by some impunctate areas; along lateral margins with numerous small, deep, confluent punctures, converging with the transverse impressions; rest of surface without punctures. Scutellum: dark brown, with red-cupreous and olive-green tinge; transversely oval and finely granulose. Elytra: apices slightly and obliquely emarginate, outer and sutural angles slightly dentiform; disc convex with weakly impressed punctate striae, punctures fine and shallow; surface with few small impressions along anterior margin, and many interstrial groups of fine punctures, usually isolated from each other, with few setae; punctures deeper and more confluent, with weak callosities laterally. Prosternum: disc moderately convex; surface with abundant small, deep, not confluent punctures laterally; with few small, deep punctures medially; prosternal process slightly convex, apex bluntly rounded. Mesosternum: divided, surface with numerous small, shallow, not confluent punctures laterally, without punctures medially. Mesepisternum and Mesepimeron: surface with numerous small, shallow punctures, with abundant setae. Metasternum: flattened with few fine punctures medially, with fine setae; numerous small, deep, not confluent punctures laterally. Metacoxae: surface with abundant small, deep, confluent punctures at middle to external lateral margin with abundant setae; few small, deep, sparse punctures at internal lateral margin, with few setae. Femora: cupreous with blue tinge; with numerous large, deep, not confluent punctures. Tibiae: cupreous with blue tinge; surface with numerous fine, shallow, not confluent punctures with 
fine, semierect setae. Tarsi: cupreous with blue tinge. Abdomen: with first ventrite weakly concave along midline, this concavity with scarce fine punctures with fine setae and not bordered by carina; other ventrites convex; apex of last visible ventrite feebly rounded with weak emargination at middle; surface of each ventrite sparsely and irregularly punctate medially, punctures smaller, shallow, confluent laterally, and with abundant setae. Male genitalia as in Fig. 35.

Female. Length 15.2-27.7 mm; width 5.4-10.5 mm. Differs from male as follows: more robust in body shape.

Variation. This species (34 males and 36 females examined) varies in the coloration; pronotum usually dark brown to reddish cupreous.

Differential diagnosis. Similar to Lampetis torquata and L. aurata. Lampetis torquata ventral surface is olive green at middle, becoming purplish toward the sides; scutellum bronzy green; elytra with a longitudinal groove along the lateral margins, reliefs dark green, and impressions bronzy green margined with purple. L. aurata ventral surface is bluish black with strong greenish or violaceous tinge, impressions golden-green; head golden green; pronotum black with a faint bluish tinge, impressions golden green, with a deep longitudinal groove at middle, and a rather broad depression on each side along the anterior margin; scutellum bluish black.

Type material studied. Male holotype: [Eleuthera Bahamas/ July 9-15, Wickham.] [Type No./ 26806/ U.S.N.M.] [Psiloptera/ bahamica/ Fisher] (USNM).

Distribution. This species has been collected only in Bahamas from the following District and localities: Andros Islands; East Bimini Island; Eleuthera: Rainbow Bay; Exuma: Wanderick Wells Cay; Ragged Island: Buena Vista Cay; South Bimini Island; Long Island: Clarence Town.

Phenology. Collected from January to November.

Lampetis (Spinthoptera) chalconota (Waterhouse, 1882) (Figs 5, 36)

Psiloptera chalconota Waterhouse, 1882: 9; 1889: 173; Kerremans, 1885: 132; 1892: 58; 1903: 94; 1910: 155.

Psiloptera (Lampetis) chalconota; Obenberger, 1926: 164; Blackwelder, 1944: 310.

Lampetis (Spinthoptera) chalconota; Kurosawa, 1993: 580.

Diagnosis. Dorsal surface red-coppery medially, bright green laterally, impressions bright green; ventral surface bright red-coppery; punctures bright green with short, recumbent, white setae; first antennal segment bright green, the rest dark brown with bright green and violet or blue tinge; pronotum flattened in midline toward base, along anterior margin to middle a strong line formed by bead-like small punctures; elytral surface red-coppery up to the fourth striae, bright green toward lateral margins, apices bright green with blue tinge, disc with feebly impressed punctate striae; first ventrite slightly concave along midline, ventrite 2 slightly flattened along midline.

Male redescription. Length $16.1-25.5 \mathrm{~mm}$; width 5.5-9.0 mm. Head: Punctures bright green or bluishgreen; labrum bright green with brassy and red-coppery tinge, with few small, shallow, confluent punctures; clypeus bright green with brassy or cupreous tinge with abundant larger, deeper, confluent punctures than labrum, punctures bluish-green; frons bright green, callosities with red-coppery tinge, flattened, with abundant large, deep, confluent punctures; vertex surface bright green with red-coppery tinge, with few small, deep, sparse punctures; mandibles bright green with bluish tinge on bases, with numerous large, deep, confluent punctures; palpi bright green with bluish tinge. Pronotum: 1.5 times wider than long, widest at middle, lateral margins slightly concave, expanded at middle, then obliquely converging to anterior angles; narrowest anteriorly; lateral margin slightly carinate in the middle; anterior and posterior margins slightly bisinuate, each with weak, broad median lobe; posterior angles slightly acute; disc moderately convex, flattened in midline toward base; surface with large, deep, sparse punctures, forming groups in certain areas medially, punctures more confluent toward lateral margins, with numerous weak callosities; along anterior margin with a strong line formed by small, bead-like confluent punctures interrupted medially. Scutellum: bright green with cupreous or blue tinge, small, slightly transversally oval. Elytra: color red-coppery up to the fourth striae, bright green toward lateral margins, apices bright green with blue tinge; apices obliquely and weakly emarginate, outer and sutural angles slightly dentiform; disc moderately convex, with feebly impressed punctate striae; surface transversely impressed basally; intervals with small, confluent punctures, and finely punctate interstrial impressions, usually isolated from each other, but becoming more confluent toward lateral margins, with numerous small, dark green or bright green callosities. Prosternum: anterior margin weakly emarginate at middle; disc moderately convex, rugosely punctate laterally, with few sparse punctures medially; prosternal process red-coppery with greenish tinge; flattened; sulci with small, shallow, confluent punctures with few large setae, apex bluntly rounded. Mesosternum: red-coppery medially; bright green with red-coppery tinge laterally; with numerous small, deep punctures laterally; without punctures medially. Mesepisternum and Mesepimeron: red-coppery, with few large, shallow, sparse punctures. Metasternum: red-coppery with greenish tinge medially; flattened with fine, sparse punctures medially; large, deep, not confluent punctures laterally. Metacoxae: along posterior margin with a line of small, shallow punctures with scarce setae; toward external lateral margin with few large, deep, sparse punctures; internal lateral margin with scarce fine punctures; numerous small, deep, confluent punctures medially. Femora: surface bright red-coppery with green and blue tinge, punctures bright green, with numerous large, shallow punctures. Tibiae: surface bright green internally, violet externally, with numerous small, not confluent punctures. Tarsi: violet with bluish tinge. Abdomen: surface red-coppery with brassy and bluish tinge; first ventrite slightly concave along midline, concavity narrow with numerous small, shallow punctures, and bordered by impunctate carina; ventrite 2 slightly flattened along midline; ventrites 3-5 convex; apex of last visible ventrite feebly rounded with weak emargination at 


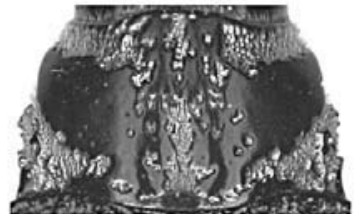

62

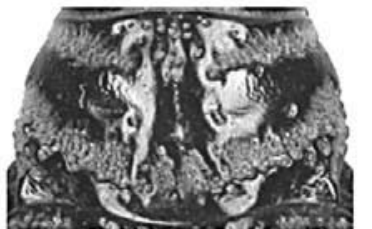

66

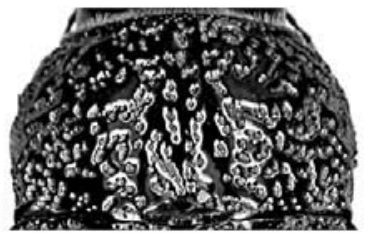

70

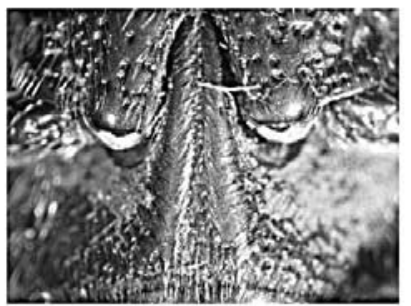

74

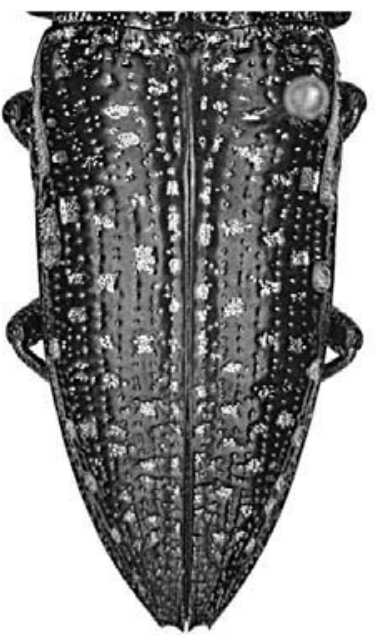

78

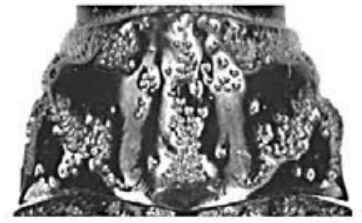

63

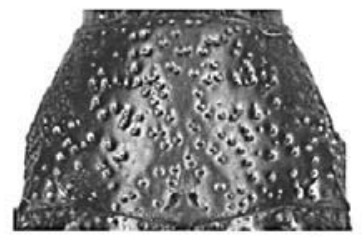

67

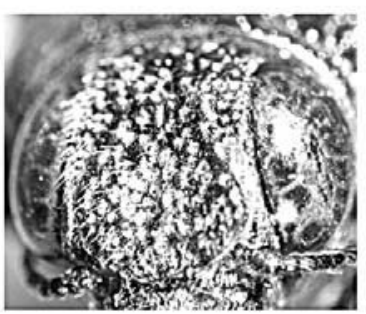

71
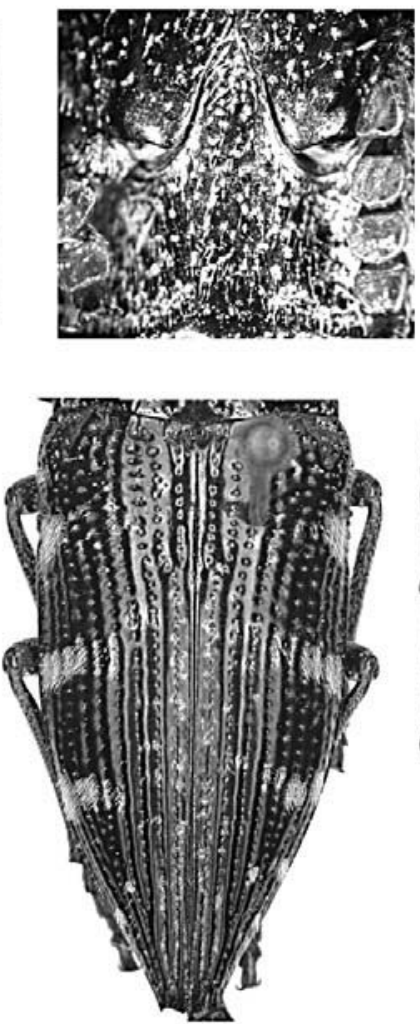

79
75

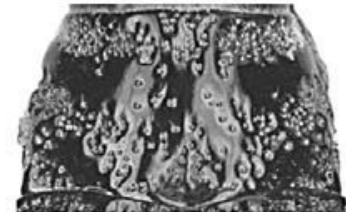

64

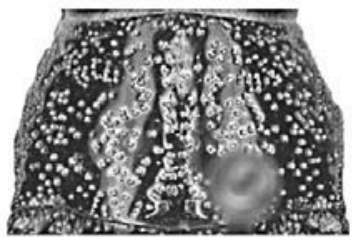

68

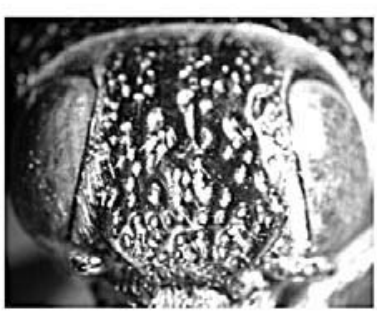

72

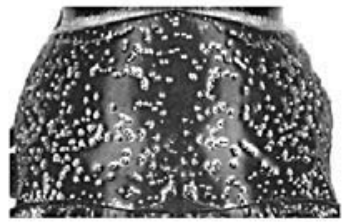

69

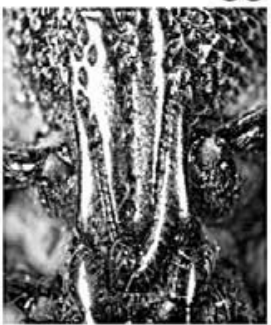

73

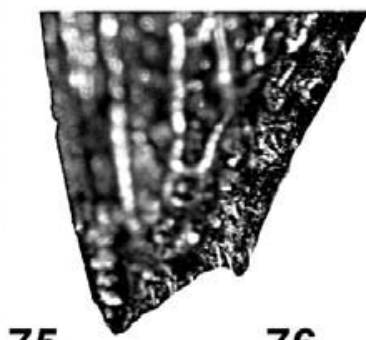

76

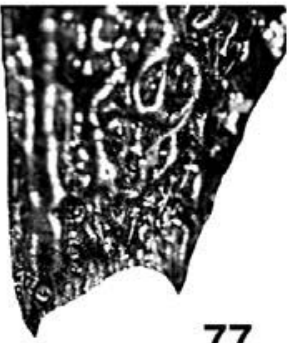

77

Figs 62-81: Pronotum: 62 - Lampetis (Spinthoptera) aurata (Saunders, 1871); 63 - L. aurifera (Olivier, 1790); 64 - L. bahamica (Fisher, 1925); 65 - L. straba (Chevrolat, 1867); 66 - L. torquata (Dalman, 1823); 67 - L. guildini (Laporte \& Gory, 1836 ); 68 - L. cupreopunctata (Schaeffer, 1905); 69 - L. auropunctata (Kerremans, 1893); 70 - L. drummondi (Laporte \& Gory, 1836); Head, anterior view: $71-$ L. tigrina sp. n.; $72-$ L. simplex (Waterhouse, 1882); Prosternal process: 73 - L. guildini (Laporte \& Gory, 1836); Processus intercoxalis of the first ventrite: 74 - L. obscura Thomson, 1879; 75 - L. drummondi (Laporte \& Gory, 1836); Elytral apex: 76 - L. christophi Théry, 1923; 77 - L. chamela sp. n.; Elytra: 78 - L. auropunctata (Kerremans, 1893); 79 - L. hirtomaculata (Herbst, 1801); 80 - L. drummondi (Laporte \& Gory, 1836); 81 - L. webbii (LeConte, 1858). 
middle; abdominal surface with numerous shallow, confluent punctures with abundant setae. Male genitalia as in Fig. 36.

Female. Length 18.9-29.8 mm; width $6.5-10.7 \mathrm{~mm}$. Differs from male as follows: more robust in body shape.

Variation. This species (40 males and 47 females examined) varies in the coloration; dorsal surface with the usual bright green to bluish green laterally; ventral surface red-coppery to red-coppery with reliefs dark green or bluish green sometimes; labrum from bright green with brassy and red-coppery tinge to bright green with brassy, red-coppery and blue tinge; clypeus bright green with brassy or cupreous tinge to cupreous or dark green; frons bright green to brassy, callosities with red-coppery to cupreous or dark green tinge; vertex bright green to cupreous or dark green; mandibles bright green with bluish tinge to dark or bright green with cupreous tinge; antennae from dark brown with bright green and violet or blue tins to dark brown with brassy green and cupreous tinge; scutellum bright green with cupreous or blue tinge to cupreous or dark green.

Differential diagnosis. Lampetis chalconota is similar to L. viridimarginalis $\mathrm{sp}$. $\mathrm{n}$. Lampetis viridimarginalis $\mathrm{sp}$. $\mathrm{n}$. ventral surface is metallic red with greenish and brassy tinge, punctures bright green; dorsal surface with punctures bright green margined with dark green; frons sinuate; first antennal segment metallic red with greenish tinge, the rest black with reddish and greenish or bluish tinge; pronotum metallic red medially, metallic red with green tinge laterally, surface with few small, deep punctures, with impunctate areas medially; elytra metallic red medially, bright green laterally, apices reddish, disc slightly impressed with punctate striae, surface with few small, finely punctate interstrial impressions, and intervals with scarce fine, shallow, confluent punctures; first abdominal ventrite slightly concave along midline, concavity wide, other ventrites convex.

Type material studied. Male lectotype: [SYN-/TYPE] [Cuernavaca] [Mexico/Salle coll./525] [Mexico/ B./B./ chriso/ cincta./Mihi.] [Mexico/ B./ Lampe,/tis/ chalco,/ nota./ Ver. Mus.] [B.C.A., III./ Psiloptera/ chalconota] [Lectotype/ A.M. Corona des./ 2004] (BMNH). Female paralectotype: [SYN-/TYPE] [Puebla/ Mexico./ Salle Coll.] [525] [Psiloptera/ chalconota/ Klug./ = chrysocincta, Steum/ afund Sallé.] [B.C.A., III./ Psiloptera/ chalconota.] [Paralectotype/ A.M. Corona des./ 2004] (BMNH).

Distribution. Known from Guatemala and Mexico. In Guatemala: Zacapa: 12-14 km S San Lorenzo. In Mexico it has been found from the following states: Estado de Mexico: Malinalco; Temascaltepec de González; Guerrero: Amula; $3.3 \mathrm{~km} \mathrm{NE}$ Cacahuamilpa; 4 mi N Chilpancingo; $3 \mathrm{mi} \mathrm{N}$ Chilpancingo; 9 km NW Chilpancingo, on road to Chichihualco; $9.3 \mathrm{~km} \mathrm{NW}$ Chilpancingo on road to Chichihualco; Michapa; $22 \mathrm{~km} \mathrm{E}$ Chichihualco; $38 \mathrm{~km} \mathrm{~W} \mathrm{Iguala;} 10 \mathrm{~km} \mathrm{~N}$ Iguala; $10.5 \mathrm{~km} \mathrm{~N}$ Iguala; $40 \mathrm{~km} \mathrm{~W}$ Iguala; 9-10 km S Ixcateopan; 5-7 km NW Taxco; $2.5 \mathrm{~km} \mathrm{~S}$ Taxco; $12 \mathrm{~km}$ E Telolapan; $10 \mathrm{~km} \mathrm{SW} \mathrm{Xochi-}$ pala; Xochicalco; Michoacan: Hwy. 155 mi S Tuxpan; 4 mi S Tuxpan; 8 mi SW Tuxpan; Morelos: Cuautla; Cuernavaca; 12 mi E Cuernavaca; Cañón del Lobo, $20 \mathrm{~km}$ E Cuernavaca; Xochicalco; Yautepec; Yecapixtla; Oaxaca: 3-5 km N Huajuapan de León; Puebla: 33.8 mi SE Acatlán; Temascal.
Adult host plants. Acacia farnesiana, Acacia sp., Mimosa sp., and Sumacrhus sp. (Fabaceae).

Phenology. Collected from June to November.

\section{Lampetis (Spinthoptera) chamela sp. $\mathbf{n}$.}

(Figs 6, 37, 77)

Diagnosis. Dorsal surface metallic red with brassy green tinge; ventral surface metallic red; punctures and impressions bright green, punctures with short, recumbent, white setae; first antennal segment metallic red with greenish tinge, the other dark brown; elytra with slightly impressed punctate striae, three striae visible, surface with many finely punctate interstrial impressions, usually isolated from each other medially, these impressions confluent in transverse and oblique groupings laterally; first ventrite slightly concave along midline, bordered by impunctate carina, ventrite 2 flattened along midline.

Male description. Length 21.5-27.2 mm; width 7.5-9.8 mm. Head: Metallic red with brassy green tinge; labrum metallic red with small, shallow, confluent punctures; clypeus with anterior margin emarginate in the middle, with few shallow punctures of different size along anterior and posterior margins; frons flattened, with numerous deep, small, confluent punctures with many strong callosities; vertex with numerous confluent punctures; mandibles with small, deep, not confluent punctures on bases; maxillary palpi metallic red with brassy green tinge. Pronotum: 1.6 times wider than long, widest at base and middle; lateral margins subparallel at base, weakly expanded at middle, and weakly converging to anterior angles; narrowest apically; lateral margins discontinuously carinate medially to posterior margin; anterior and posterior margins slightly bisinuate, each with weak, broad median lobe; posterior angles slightly acute; disc moderately convex, flattened in the midline toward base; surface with small, deep, sparse punctures medially, with irregular impunctate areas; abundant, confluent punctures, with weak, few callosities laterally. Scutellum: metallic red with bright green tinge, small, rounded or slightly oval. Elytra: apices obliquely emarginate and bidentate; disc moderately convex, with slightly impressed punctate striae, three finely punctate striae visible; surface with few transversal impressions basally and many finely punctate interstrial impressions, usually isolated from each other medially, becoming transversely and obliquely confluent toward lateral margins, with numerous small callosities. Prosternum: anterior margin weakly sinuate at middle; disc moderately convex, with numerous small, deep, confluent punctures, with few setae; scarce punctures medially; prosternal process flattened, sulci with fine punctures and with few setae, apex bluntly rounded. Mesosternum: with numerous small, shallow punctures laterally, without punctures medially. Mesepimeron and Mesepisternum: with numerous small, shallow, sparse punctures. Metasternum: flattened medially, with scarce fine punctures; large, deep, confluent punctures laterally. Metacoxae: along posterior margin to middle with a line of small, deep, confluent punctures with few setae; large, deep, punctures in groups of three 
or four medially to external lateral margin, with some impunctate areas; toward internal lateral margin with scarce fine punctures. Femora: surface metallic red with punctures bright green, with numerous deep, not confluent punctures, larger than punctures of tibiae. Tibiae: surface metallic red with punctures bright green; with abundant small, shallow, confluent punctures. Tarsi: metallic red with bluish and greenish tinge; with few setae. Abdomen: first ventrite slightly concave along midline, concavity broad with small, shallow punctures and bordered by impunctate carina; ventrite 2 flattened along midline; ventrites 3-5 convex; apex of last visible ventrite truncate with weak emargination at middle; abdominal surface with numerous small, irregular punctures laterally, with impunctate areas medially. Male genitalia as in figure 37.

Female. Length 18.4-30.4 mm; width 6.4-10.9 mm.

Differential diagnosis. Lampetis chamela sp. $\mathrm{n}$. is similar to L. cortesi. Lampetis cortesi has ventral surface red-cupreous; punctures aeneocupreous; first antennal segment red-cupreous, the rest black with bronze tinge at light; pronotum black with reddish tinge; elytra black, with slightly impressed punctate striae, four striae visible; apices obliquely emarginate, outer angle dentiform; first abdominal ventrite slightly concave along midline, ventrite 2 slightly concave at anterior margin.

Type material. Male holotype: [MEXICO: JALISCO Estacion/ de Biologia Chamela/ 26-IX-85/ F.A. Noguera M.] (EBCC). 26(6M, 20F) Paratypes: [MEXICO, Jalisco/ Est. Biol. Chamela/ 12-VII-1993/ R.L. Westcott] (1M, RLWE); [H. Brailovsky A./ Estación de Biologia/ Chamela-Jalisco/ 22-VIII-76/ Mexico] (1F, CNIN); [MEXICO: JALISCO Estacíon/ de Biologia Chamela/ 25-IX-85/ F.A.Noguera M.] (1F, RLWE); [MEXICO: JALISCO Estacion/ de Biologia Chamela/ M Sánchez 25-IX-85] (1F, EBCC); [MEXICO: JALISCO Estacion/ de Biologia Chamela/ M Sanchez 3-XI-85] (1F, EBCC); [MEXICO: JALISCO: ESTACION DE/ BIOLOGIA CHAMELA 25-VIII-86/ M. Sánchez] (1F, EBCC); [MEXICO: JALISCO: ESTACION DE/ BIOLOGIA CHAMELA/ 30-VIII-1986 FANM 397] [COLECT: FELIPE A. NOGUERA M.] (2F, EBCC); [MEXICO: JALISCO: ESTACION DE/ BIOLOGIA CHAMELA/ 22.IX'86 FANM 410] [COLECT: FELIPE A. NOGUERA M.] (1F, EBCC); [MEXICO: Jalisco/ Chamela FANM 415/ 29-IX-1986/ Coll.F.A.Noguera] (1F, EBCC); [MEXICO: JALISCO: ESTACION DE/ BIOLOGIA CHAMELA/ 16.X'86 FANM 420] [COLECT: FELIPE A. NOGUERA M.] (1F, EBCC); [Estacion de Biologia,/ Chamela, Jalisco,/ Mex. 18-X-1986/ Coll. J.D. McCarty] (1M, JMCC); [MEXICO: Jalisco/ Chamela/ 25·IX'1987/ Coll. E.A.Noguera] (1F, EBCC); [MEXICO, Jalisco/ Est. Biol. Chamela/ 9/10-X1988/ Westcott \& Mudge] (1F, RLWE); [MEXICO: JALISCO: ESTACION DE/ BIOLOGIA CHAMELA/ 28-XI-1988/ E. Ramírez R.A.] (1F, EBCC); [Estacion de Biologia,/ Chamela, Jalisco,/ Mex. 6-XII-1988/ Coll. J.D. McCarty] (1M, JMCC); [MEXICO: JALISCO: ESTACION DE/ BIOLOGIA CHAMELA/ 27-X-1989/ A. Chema's] (1M, EBCC); [MEXICO, Jalisco/ Est. Biol. Chamela/ 27-29/VII/1990/ R.L. Westcott] (1F, RLWE); [México: Jalisco/ Est. Biol. Chamela/ 8-I-1991/ Col. F.A. Noguera] (1F, EBCC); [MEXICO, Jalisco/ Cuitzmala, vic./ Est. Biol. Chamela/ 10-X-1988/ R.L. Westcott] (1F, RLWE); [13 km. WNW Barra de Navidad/ (Bahia Tenacatita) Palm grove/ VIII-20-64 Wm. L. Nutting] (1F, GHNC); [MEXICO: JALISCO: CARR. BARRA/ NAVIDAD-PTO. VALLARTA
KM.17/ 26-VIII-86] [COLECT: T.H. ATKINSON] (1M, RLWE); [MEXICO, Jalisco/ $22 \mathrm{~km} \mathrm{SW}$ Llano/ Grande $270 \mathrm{~m} /$ 28-VI-1995/ R.L. Westcott] (1M, RLWE); [MEX: Jal./ Tapaixtes/ 5-IX-86 RA. Usela] (1F, EBCC); [MEXICO: Jalisco/ 34 km E Tomatlán/ 3-VIII-1994/ Col. F.A. Noguera] (1F, EMEC); [MEX. VII·1·62/ Nayarit 12 mi.,/ E San Blas] [E. Sleeper, R. An-/ derson, A. Hardy,/ R. Somerby Collr.] (1F, DSVC).

Etymology. The name of this species, a noun in apposition, refers to the Mexican locality where the specimens were collected.

Distribution. This species has been collected only in two states in Mexico: Jalisco: Estación de Biología Chamela; Cuitzmala, vic. Est. Biol. Chamela; 13 km WNW Barra de Navidad, Bahia Tenacatita, Palm grove; km 17 carr. Barra de NavidadPto. Vallarta; 22 km SW Llano; Tapaixtes; 34 km E Tomatlán; Nayarit: 12 mi E San Blas.

\section{Lampetis (Spinthoptera) chiapaneca Corona, 2004}

(Figs 7, 38)

\section{Lampetis (Spinthoptera) chiapaneca Corona, 2004: 159}

Diagnosis. Dorsal and ventral surface metallic red, punctures bright green; antennae dark brown; prosternal and mesosternal surface metallic red with greenish tinge; pronotum slightly wider than long, lateral margins subparallel at posterior margin, weakly expanded at middle, then obliquely converging to anterior angles, punctures closer in the middle and becoming sparse toward base with extensive impunctate areas, punctures moderately coarse, more confluent laterally and with slight rugosities; elytral margins and apices bright green, disc with moderately impressed punctate striae, and few finely punctate small interstrial impressions, these commonly confluent in transverse and oblique groupings; first ventrite with midline concavity margined by smooth carina, sternum 2 slightly concave near anterior margin; sterna 3-5 convex.

Distribution. From 12 males and 8 females examined, this species has been collected only in one state in Mexico: Chiapas: $19 \mathrm{~km} \mathrm{~S} \mathrm{La} \mathrm{Trinitaria;} 2 \mathrm{mi} \mathrm{N}$ Suchiapa; $5 \mathrm{~km} \mathrm{~S}$ Tuxtla Gutiérrez; $17 \mathrm{~km} \mathrm{~W}$ Tuxtla Gutiérrez; $18 \mathrm{~km} \mathrm{~W}$ Tuxtla Gutiérrez.

Adult host plant. Larval habits are unknown. Adults resting on branches of Acacia sp. (Corona, 2004).

Phenology. Collected from July to October.

\section{Lampetis (Spinthoptera) christophi (Théry, 1923)}

(Figs 8, 39, 76)

Lampetis christophi Théry, 1923: 251.

Psiloptera (Lampetis) christophi; Obenberger, 1926: 164; Blackwelder, 1944: 310.

Lampetis (Spinthoptera) christophi; Kurosawa, 1993: 580.

Diagnosis. Dorsal and ventral surfaces dark brown with olive-green and purple tinge, punctures with short, recumbent, white setae; dorsal surface with punctures olive green margined with purple; ventral surface with punctures purple; pronotum lateral margins slightly concave at base, slightly expanded at middle, then obliquely converging to anterior angles; elytra with purple tinge laterally, apices purple, disc slightly convex, with slightly impressed punctate striae, first three striae clearly visible, impressions purple; first ventrite slightly concave along midline, ventrites $2-5$ convex. 
Male holotype redescription. Length $22.0 \mathrm{~mm}$; width $7.0 \mathrm{~mm}$. Head: Punctures purple, with short, recumbent, white setae; labrum dark brown with purple tinge, with small, shallow, confluent punctures; clypeus dark brown with purple tinge, with anterior margin sinuate at middle, with scarce small, shallow punctures near to base; frons dark brown with purple and olive-green tinge, flattened, with numerous small, deep, confluent punctures, with abundant setae, and numerous small callosities; vertex dark brown with olive-green tinge, with small, deep punctures; mandibles dark brown with purple tinge, with numerous small, deep, confluent punctures on bases; maxillary palpi dark brown with purple tinge, with abundant setae; first antennal segment purple, the rest dark brown, with olive-green tinge. Pronotum: 1.7 times wider than long, widest at middle; lateral margins slightly concave at base, slightly expanded at middle, then obliquely converging to anterior angles; narrowest apically; lateral margins discontinuously and slightly carinate medially to base; anterior margin weakly bisinuate with weak median lobe; posterior margin slightly bisinuate, with broad median lobe; posterior angles slightly acute; disc moderately convex, flattened in the midline toward base with scarce punctures; at both sides of midline with numerous small, deep, confluent punctures; most abundant and confluent punctures, with few small, weak callosities laterally. Scutellum: dark brown with purple and olivegreen tinge, small, rounded. Elytra: dark brown with olive-green tinge medially, purple tinge laterally; apices purple, obliquely emarginate, bidentate; disc slightly convex, with slightly impressed, finely punctate striae, first three striae clearly visible; surface with few impressions basally; with many finely punctate small interstrial impressions, usually confluent in transverse and oblique groupings, and more abundant and confluent toward lateral margins; numerous small, weak callosities laterally. Prosternum: disc moderatly convex, with numerous small, deep confluent punctures medially, more abundant and confluent laterally, with weak callosities; prosternal process convex; sulci with two or three lines of brassygreen, small, deep punctures, and abundant setae; apex bluntly rounded. Mesosternum: with numerous small, deep, confluent punctures laterally, and abundant setae; without punctures medially. Mesepimeron and Mesepisternum: with numerous small, shallow, sparse punctures. Metasternum: purple medially; dark brown with purple tinge laterally; surface flattened, with few fine punctures, not confluent, and clothed with fine setae medially; laterally with numerous small, shallow, confluent punctures, with some impunctate areas. Metacoxae: numerous small, deep, confluent punctures medially; toward internal lateral margin, with scarce fine punctures; toward external lateral margin with few small, deep, sparse punctures; a line of small, deep, confluent punctures at posterior margin to middle. Femora: surface dark brown with purple tinge; with few small, shallow, punctures, and impunctate areas medially; laterally with abundant small, shallow punctures. Tibiae: surface dark brown, with purple tinge; with abundant small, shallow, confluent punctures. Tarsi: dark brown, olive-green tinge. Abdomen: first ventrite slightly concave along midline, with numerous small, shallow, confluent punctures, and abundant setae, this concavity narrow and bordered by impunctate and smooth carina; ventrites 2-5 convex; apex of last visible ventrite feebly rounded with weak emargination at middle; abdominal surface densely and irregularly punctate, with abundant small, shallow, confluent punctures. Male genitalia as in figure 39.

Female. Length 16.1-19.7 mm; width 5.7-7.0 mm.

Differential diagnosis. Lampetis christophi is similar to L. simplex. Lampetis simplex dorsal surface is black; ventral surface bright red medially, black with red tinge laterally; punctures cupreous margined with red; first antennal segment red, the rest black with reddish tinge; pronotum surface with numerous small, deep, sparse punctures medially; elytra disc with strongly impressed punctate striae, sixth interval with few small punctures; and first ventrite feebly concave along midline.

Type material studied. Male holotype: [MEXICO] [christophi/ Théry/ Type] [MUSÉUM PARIS/ 1935/ Coll. A. THÉRY] (MNHN).

Variation. This species ( 2 males and 2 females examined) varies in the coloration; punctures and tinge from purple to redcoppery.

Distribution. This species has been found only in southern Mexico from the following locality: Chiapas: $9 \mathrm{mi} \mathrm{NW} \mathrm{El} \mathrm{Oco-}$ tal.

Phenology. Collected on August.

\section{Lampetis (Spinthoptera) colima sp. $\mathbf{n}$.}

(Figs 9, 40)

Diagnosis. Dorsal and ventral surfaces black with reddish tinge, punctures and impressions cupreous; punctures with short, recumbent, white setae; pronotal suface with sparse, small punctures medially; punctures more numerous bigger, confluent laterally, with few weak callosities; elytral disc moderately convex with slightly impressed punctate striae, four striae visible; surface with many small interstrial impressions, usually isolated from each other; first ventrite weakly concave along midline, concavity bordered with weak carina; second ventrite flattened at midline.

Male description. Length 23.7-26.9 mm; width 8.1-9.6 mm. Head: Punctures cupreous. Labrum black with reddish tinge, with numerous shallow, confluent punctures with numerous setae; clypeus black with cupreous tinge, anterior margin concave, with scarce punctures; frons flattened, black with reddish tinge, with numerous large, deep punctures with few setae, and with strong callosities; vertex black, with few punctures; bases of mandibles black with reddish tinge, with numerous small, not confluent punctures, with few setae; maxilary palpi black with reddish tinge; antennae black with cupreous tinge. Pronotum: 1.6 times wider than long, widest at middle and posterior margin; lateral margins subparallel at base, scarcely expanded at middle, then scarcely obliquely converging to anterior angles, narrowest anteriorly; lateral margins carinate; anterior and posterior margins weakly bisinuate; posterior margin with 
broad, weak median lobe; posterior angles slightly acute; disc moderately convex, flattened in midline toward posterior margin; surface with sparse, small punctures medially; laterally with numerous confluent punctures, and few weak callosities. Scutellum: black with reddish tinge, rounded. Elytra: apices obliquely emarginate, bidentate; disc moderately convex with slightly impressed punctate striae, four striae visible; surface with numerous impressions along base and with many small interstrial impressions, commonly isolated from each other and bigger laterally, and with numerous small, weak callosities laterally. Prosternum: anterior margin slightly sinuate; disc moderately convex; surface without punctures at midline, numerous small, confluent punctures with few setae laterally, with few weak callosities; prosternal process flattened, sulci with fine punctures, and few setae, apex bluntly rounded. Mesosternum: surface with numerous confluent punctures laterally, without punctures medially. Mesepimeron and mesepisternum: with few sparse punctures. Metasternum: flattened with numerous fine punctures medially; with numerous not confluent punctures laterally. Metacoxae: surface with abundant small, deep, confluent punctures medially toward external lateral margin; toward internal lateral margin with numerous fine punctures; along posterior margin with small, deep, confluent punctures; punctures with few seate. Femora: black with reddish tinge, with abundant not confluent cuperous punctures, with numerous setae. Tibiae: black with reddish tinge, punctures cupreous; densely punctate, with small, shallow punctures, with numerous setae. Tarsi: bright green with reddish and cupreous tinge, with numerous setae. Abdomen: with first ventrite slightly concave along midline, this concavity with few fine punctures and bordered with weak carina; second ventrite flattened at midline, other ventrites convex; apex of last visible ventrite truncate with weak emargination at middle; abdominal surface densely, coarsely punctate and with few setae. Male genitalia as in Fig. 40.

Female. Length 27.9-28.9 mm; width 9.6-10.4 mm.

Variation. This species varies in the coloration. Dorsal and ventral surfaces, and tibiae from black with reddish tinge to black with greenish and reddish tinge.

Differential diagnosis. Lampetis colima sp. $\mathrm{n}$. is similar to L. chamela sp. n. and L. hondurensis sp. n. Lampetis chamela sp. $\mathrm{n}$. dorsal surface is metallic with red tinge; ventral surface metallic red with brassy green; punctures and impressions bright green; first antennal segment metallic red with greenish tinge, the other dark brown; elytra with slightly impressed punctate striae, three striae visible; first ventrite slightly concave along midline. L. hondurensis has entire surface dark brown with bronze and purplish tinge, punctures brassy margined with purple; antennae black with bronze tinge; elytral disc with moderately impressed punctate striae, with scarce impressions along base and few punctate interstrial impressions; first abdominal ventrite slightly concave along midline.

Type material. Male holotype: [MEX., Colima vic/ El Terrero 4-6000\% 30 sept 1991/ JE Wappes] (JEWC). (4M, 2F)
Paratypes: [MEXICO: Colima/ vic. El Terreo/ 2000'-4000' 1-X-91/ Morris,/ Wappes, Giesbert] (3M, RMCF); [MEXICO: COL, Minatitlán,/ El Salto, BTC-BTSC, 750M,/ 26.XI.1996, J.L. Navarrete col.] (1F, CZUG); [MEXICO: Colima/ vic. El Terreo/ 2000'-4000' 1-X-91/ Morris,/ Wappes, Giesbert] (1M, $1 \mathrm{~F}, \mathrm{RLWE})$.

Etymology. The name of this species, a noun in apposition, refers to the Mexican locality where the specimens were collected.

Distribution. This species has been found only in Mexico from the following state and county records: Colima: El Terreo; Minatitlán, El Salto; Guerrero: Chilpancingo, Palo Blanco, Sierra del Alquitrán.

Lampetis (Spinthoptera) cortesi (Laporte \& Gory, 1837)

(Figs 10, 41)

Buprestis cortesi Laporte \& Gory, 1837: 81.

Psiloptera (Lampetis) cortesi; Obenberger, 1926: 165; Blackwelder, 1944: 310.

Lampetis polymita Chevrolat, 1838: 59; Lacordaire, 1857: 29; Gemminger \& Harold, 1869: 1366; Saunders, 1871: 25; Waterhouse, 1882: 8; 1889: 10, 172; Kerremans, 1892: 59; 1903: 94; 1910: 140; Obenberger, 1926: 165; Blackwelder, 1944: 310; Holynski, 1988: 52.

Psiloptera cortesi; Gemminger \& Harold, 1869: 1366; Saunders, 1871: 25; Waterhouse, 1882: 10; Kerremans, 1892: 59; 1903: 94; 1910: 140.

Psiloptera severissima Thomson, 1879a: 11; Waterhouse, 1889: 172; Kerremans, 1892: 59; 1903: 94; 1910: 140; Obenberger, 1926: 165; Blackwelder, 1944: 310.

Lampetis (Spinthoptera) cortesi; Kurosawa, 1993: 580.

Diagnosis. Ventral surface red-cupreous; punctures and impressions aeneocupreous with short, recumbent, white setae; first antennal segment red-cupreous, the rest black with bronzy tinge at light; pronotum black with reddish tinge; elytra black, with slightly impressed punctate striae, four striae visible, surface with many finely punctate, interstrial impressions, commonly confluent in transverse groupings, with few small callosities; first ventrite slightly concave along midline, ventrite 2 slightly concave at anterior margin.

Male redescription. Length $13.9-22.8 \mathrm{~mm}$; width 4.6-8.1 mm. Head: Labrum red-cupreous, with few shallow, not confluent punctures with numerous white setae; clypeus red-cupreous, slightly concave at anterior margin, with few punctures; frons sinuate, black with redcupreous tinge, with red-cupreous punctures, with abundant small, deep punctures, with scarce weak callosities, punctures with abundant setae; vertex black with redcupreous tinge; bases of mandibles red-cupreous, with numerous small punctures, and with abundant setae; maxillary palpi red-cupreous. Pronotum: 1.6 times wider than long, widest at middle; lateral margins slightly concave at base, expanded and rounded at middle, then slightly obliquely converging to anterior angles, narrowest anteriorly; lateral margins carinate from middle to posterior margin; anterior and posterior margins slightly bisinuate; posterior margin with broad, weak median lobe; posterior angles slightly acute; disc moderately convex, flattened in midline toward posterior margin, along midline with deep, sparse punctures forming a weak depression; surface with sparse punctures with impunctate areas medi- 
ally; laterally with abundant confluent punctures, and with few weak callosities. Scutellum: black with reddish tinge, oval. Elytra: apices obliquely emarginate, outer angle dentiform; disc moderately convex with slightly impressed punctate striae, four striae visible, surface with few impressions along anterior margin, with many interstrial impressions, commonly confluent in transverse groupings, and with few small callosities. Prosternum: anterior margin slightly sinuate; disc moderately convex; surface with scarce small, deep punctures medially, numerous confluent punctures laterally, punctures with few setae; prosternal process flattened, sulci with small, deep, confluent punctures with few setae, apex bluntly rounded. Mesosternum: surface with numerous not confluent punctures laterally, without punctures medially. Mesepimeron and Mesepisternum: with few sparse punctures. Metasternum: flattened with few fine punctures medially; laterally with numerous not confluent punctures. Metacoxae: surface with abundant small, deep, confluent punctures medially; few small punctures laterally; along posterior margin with small, deep, confluent punctures, with numerous setae; posterior margin with two rounded lobes. Femora: red-cupreous, punctures aeneocupreous; with abundant not confluent punctures, with numerous setae. Tibiae: red-cupreous, punctures aeneocupreous; densely punctate, punctures small, shallow with numerous setae. Tarsi: red-cupreous, with numerous setae. Abdomen: with first ventrite slightly concave along midline, this concavity narrow with abundant fine punctures and bordered by weak impunctate carinae; ventrite 2 slightly concave at anterior margin, other ventrites convex; apex of last visible ventrite feebly rounded with weak emargination at middle; abdominal surface densely, coarsely punctate and with abundant setae. Male genitalia as in Fig. 41.

Female. Length 13.6-24.8 mm; width 4.5-8.9 mm.

Variation. This species (46 males and 44 females examined) varies in the coloration. Maxillary pali, tibiae and tarsi red-cupreous to red-cupreous with greenish tinge.

Differential diagnosis. Lampetis cortesi is similar to $L$. cupreopunctata and L. simplex. Lampetis cupreopunctata is black above with cupreous impressions and punctures, ventral surface cupreous; pronotum with weak midline impression extending from base almost to anterior margin; elytral disc with moderately impressed striae. Lampetis simplex is black above; ventral surface bright red medially, black with red tinge laterally; punctures cupreous margined with red; elytral disc with strongly impressed punctate striae, sixth interval with few small punctures; abdomen with first ventrite feebly concave along midline.

Type material studied. Psiloptera severissima: Female holotype: [Th./ Type] [Severissima/ Th. Type/ Ap. I, II./ Mex] (MNHN). Lampetis polymita: Male holotype: [Holo-/type] [Polymita/ Chevr.] (BMNH).

Distribution. This species has been collected in the following localities of Honduras and Mexico. Honduras: Comayagua: $4 \mathrm{mi}$ SW Comayagua. Mexico: Guerrero: Acapulco; La Garita; Hwy. 200, 41 km NE Ixtapa; Oaxaca: 6.7 mi SW El Camarón; 3 mi W
El Camarón; 3 m E Juchitán; 5 mi N La Ventosa; 5 km E La Ventosa; $7.5 \mathrm{~km}$ E La Ventosa; $10.5 \mathrm{~km}$ WSW Salina Cruz; 56 mi NW Santo Domingo Tehuantepec; $16 \mathrm{~km} \mathrm{NE} \mathrm{Santo}$ Domingo Tehuantepec; $12 \mathrm{mi}$ S Chivela; $30 \mathrm{mi}$ NE Santo Domingo Tehuantepec; $7 \mathrm{mi}$ W Santo Domingo Tehuantepec; $13 \mathrm{~km} \mathrm{~W}$ Santo Domingo Tehuantepec; $16 \mathrm{~km} \mathrm{NE} \mathrm{Santo}$ Domingo Tehuantepec; 7 km SSE Santo Domingo Tehuantepec; Hwy. 190, 12 km E Santo Domingo Tehuantepec; Hwy. 190, 15 km E Santo Domingo Tehuantepec; Hwy. 190, 16 km E Santo Domingo Tehuantepec; Yucatán: SW Yucatán.

Adult host plant. On Combretum sp. (Combretaceae).

Phenology. Collected from June to December.

\section{Lampetis (Spinthoptera) cupreopunctata (Schaeffer, 1905)}

(Figs 11, 42, 68)

Psiloptera cupreopunctata Schaeffer, 1905: 147; Kerremans, 1910: 141; Vogt, 1949: 196.

Spinthoptera cupreopunctata; Casey, 1909: 74.

Psiloptera (Lampetis) cupreopunctata; Nelson, 1986: 275.

Diagnosis. Dorsal surface black with cupreous punctures and impressions; ventral surface cupreous; frons, clypleus and labrum cupreous, vertex black; frons slightly sinuate; antennae cupreous at bases, black with cupreous tinge distally, pronotum with slight midline impression extending from posterior margin to anterior margin, surface coarsely punctate becoming denser laterally; elytral surface with striae moderately impressed and with many small cupreous impressions, apices obliquely truncate, outer angles dentiform; first ventrite concave along midline, ventrite 2 with weak midline concavity toward anterior margin. Male genitalia as in Fig. 42.

Distribution. From 29 males and 31 females examined, this species has been collected in northern México and the USA (new records). In northern Mexico, state and county records include the following: Nuevo León: Apodaca; Monterrey; $10 \mathrm{mi}$ W Linares; Villa Juárez; San Luis Potosí (new record for Mexico): 7 mi E.N.E. Tamuin; El Salto; Tamaulipas: $14 \mathrm{mi} \mathrm{S}$ Antiguo Morelos; 15 mi NE Jaumave; Matamoros; Naranjo; 5 mi E Nuevo Morelos; Veracruz (new record for Mexico): $26 \mathrm{mi}$ E Cordoba; $1 \mathrm{mi}$ N Rinconada; $5 \mathrm{mi}$ NE Tinajas; Xalapa; $14 \mathrm{mi}$ SE Xalapa. In the USA county records include the following: Texas: Hidalgo; Anzalduas; Cameron.

Adult host plants. On Acacia farnesiana, Acacia sp., Mimosa sp. and Prosopis juliflora (Fabaceae). According to Nelson (1986) adults are reported on Acacia farnesiana (Fabaceae), occasionally on Bumelia celastrina (Sapotaceae), and Sorghum sp. (Poaceae).

Phenology. Collected from July to November.

\section{Lampetis (Spinthoptera) cyanitarsis sp. $\mathbf{n}$.}

(Figs 12, 43)

Diagnosis. Dorsal surface bright green with reddish tinge medially and laterally, punctures bright green margined with blue or violet; ventral surface red-coppery medially, bright green with reddish and brassy tinge laterally, punctures bright green; punctures with short, recumbent, white setae; first antennal segment bright green with brassy tinge, the rest black with greenish tinge; elytral disc moderately convex, with slightly impressed punctate striae, surface with few impressions along base and many 
finely punctate, interstrial impressions; first ventrite slightly concave along midline; other ventrites convex.

Male description. Length 19.4-26.5 mm; width 6.5-9.1 mm. Head: Labrum bright green with brassy and cupreous tinge, with numerous small, shallow punctures; clypeus bright green with dark green and brassy tinge, punctures bright green, slightly sinuate at anterior margin, without punctures medially, with numerous small, deep, confluent punctures laterally; frons bright green, punctures bright green margined with blue or violet, flattened, coarsely and rugosely punctate with abundant small, deep, confluent punctures and numerous small callosities; vertex bright green, with few small, shallow, sparse punctures; bases of mandibles bright green, punctures bright green margined with blue or violet, with abundant small, deep, confluent punctures; maxillary palpi bright green with some brassy tinge. Pronotum: 1.5 times wider than long; widest at middle; lateral margins subparallel before base, slightly expanded at middle and obliquely converging to anterior angles; narrowest anteriorly; lateral margins carinate at middle to base; anterior margin slightly bisinuate with weak median lobe; posterior margin slightly bisinuate with slight, broad median lobe; posterior angles slightly acute; disc moderately convex, flattened in midline toward base; surface with few small, confluent punctures, forming groups, with impunctate areas medially; laterally with numerous small, deep, confluent punctures, and few weak callosities. Scutellum: bright green with brassy tinge, small, puntiform. Elytra: apices obliquely emarginate, outer and sutural angles dentiform; disc moderately convex, with slightly impressed punctate striae, with fine punctures; surface with few impressions along anterior margin, and many small, finely punctate, interstrial impressions; usually isolated from each other medially; becoming more confluent laterally; small, weak callosities laterally. Prosternum: disc moderately convex; surface with numerous small, deep, confluent punctures laterally; without punctures at midline; prosternal process flattened, sulci with fine, confluent punctures, apex bluntly rounded. Mesosternum: red-coppery medially, red-coppery with bright green tinge laterally; surface with numerous small, shallow, confluent punctures laterally, without punctures medially. Mesepisternum and mesepimeron: bright green with brassy tinge; with few small, shallow, sparse punctures. Metasternum: flattened; with few fine punctures medially, with fine setae; numerous small, deep, confluent punctures, forming groups of three or four, and with some impunctate areas laterally. Metacoxae: with few small, shallow, sparse punctures at external lateral margin; abundant and confluent at middle; few fine, sparse punctures at internal lateral margin. Femora: bright green with reddish-coppery tinge; with numerous small, deep, confluent punctures. Tibiae: bright green with reddish-coppery tinge; densely punctate, with abundant small, shallow, confluent punctures. Tarsi: bluish-green with violet tinge. Abdomen: first ventrite slightly concave along midline, this concavity wide and bordered with slight, impunctate carina, and with numerous fine punctures; other ventrites convex; apex of last visible ventrite feebly rounded with weak emargination at middle; abdominal surface with abundant small, shallow, confluent, irregular by shaped punctures. Male genitalia as in Fig. 43.

Female. Length 22.2-30.7 mm; width 7.6-10.8 mm.

Variation. This species varies in the coloration: dorsal surface with the usual bright green with reddish tinge medially and laterally to red-coppery medially and bright green laterally or red coppery with greenish tinge or dark green with violet tinge or metallic green; ventral surface red-coppery to dark green medially, bright green with reddish-coppery and brassy tinge to red-coppery with dark green laterally; punctures from bright to brassy green; femora and tibiae from bright green with reddishcoppery tinge to red-coppery with dark green tinge or bright green with brassy tinge.

Differential diagnosis. Lampetis cyanitarsis sp. $\mathrm{n}$. is similar to L. monilis and L. granulifera. Lampetis monilis ventral surface is reddish-green medially, red-coppery laterally; impressions and punctures bright green; pronotum bright green, lateral margins subparallel at base, slightly expanded at middle, then obliquely converging to anterior angles; elytral surface bright green with reddish tinge at middle, reliefs reddish and greenish, with strongly impressed punctate striae, generally after the four striae toward lateral margins with scarce finely punctate, interstrial impressions; first ventrite slightly concave along midline, ventrite 2 flattened along midline. Lampetis granulifera dorsal surface is bright green laterally, bright green with reddish and yellowish tinge medially; ventral surface reddish-green medially, red-coppery with yellowish tinge laterally; punctures bright green; impressions yellowish; pronotal lateral margins slightly concave at base, slightly expanded at middle, then obliquely converging to anterior angles; elytral disc with strongly impressed punctate striae and after the second striae with many finely punctate interstrial impressions; first ventrite slightly concave along midline, ventrite 2 flattened along midline.

Type material. Male holotype: [MEXICO: Morelos/ $2.5 \mathrm{~km}$ N, 4 km O Huautla/ Estación CEAMISH/ 5-IX-1996 Alt. 940 $\mathrm{m} / 18^{\circ} 27^{\prime} .671 \mathrm{~N} 99^{\circ} 02^{\prime} .475 \mathrm{O} / \mathrm{s} /$ Conzattia multifloral Col. F. A. Noguera] (EBCC). 32(12M, 20F) Paratypes: [COLIMA,

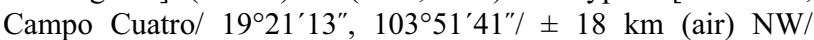
Colima, 1300-1375 m/ 7-X-1999, R.L. Westcott] (2F, RLWE); [MEXICO: Gro.;/ Iguala/ VIII-17-1981] [JA Chemsak/ A.M Michelbacher] (1F, EMEC); [MEX: Guerrero,/ $16 \mathrm{~km} \mathrm{NW}$ Iguala/ IX-12/15-1982/ elev. 1160 m] [J.A. Powell/ J.A. Chemsak/ collectors] (1M, EMEC); [MEX: Guerrero,/ $13 \mathrm{~km}$ NW Iguala/ IX-12-1982/ elev. 1220 m] [J.A. Powell/ J.A. Chemsak/ collectors] (1F, EMEC); [CACAHUAMILPA, GRO. V-9-48/ C. Bolivar] (1F, CNIN); [MICHAPA, GRO./ 2-IX-49/ C. Bolivar] (1M, CNIN); [MEXICO Guerrero/ $40.7 \mathrm{mi}$. N. Zumpango/ del Río, 3,375 ft./ 2 August 1962/ U. Kans. Mex. Exped.] (1F, KSBC); [MEXICO Guer/ $1 \mathrm{~km} \mathrm{~S} \mathrm{Taxco/}$ 15.X.1994/ FTHovore] (1F, CLBC); [NEAR AUTLAN/ JALISCO, MEX./ Y. DAWSON/ 27 DEC. 46] (1M, LACM); [MEXICO, Jalisco/ $7 \mathrm{~km}$ NNE, $2 \mathrm{~km} \mathrm{SW/} \mathrm{Autlán,} 885 \mathrm{~m} /$ 4.X.91. R.L. Westcott] (1M, RLWE); [MEXICO, Jalisco/ Autlán/ 21-III-2001/ A. Rodríguez. col.] [Cerrito la capilla/ Matorral/ Alt. 1,100 m/ Colecta directa] (1M, EBCC); [MEX- 
ICO: Jalisco/ 4 km SE Cuautla/ 16-VII-1993 Alt. 1570 m/ Cols. A. Rodríguez/ y F.A. Noguera] (1M, RLWE); [JALISCO, 8 km NW/ Ayutla $1570 \mathrm{~m} /$ mixed oak-acacia/ 16-VII-1993/ R.L. Westcott] (1M, RLWE); [MEXICO: Jalisco/ 4 km SO San Bue-

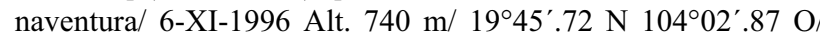
Col. M.E. Guardado $1 \mathrm{SBV}$ ] (1F, EBCC); [MEXICO: Jalisco/ $6.6 \mathrm{~km}$ SO San Buenaventura/ 3-XII-1996 Alt. $840 \mathrm{~m} / 19^{\circ} 45^{\prime} .06$

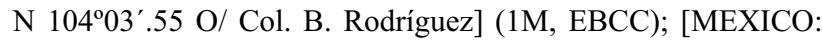
Jalisco/ San Buenaventura/ 5-VII-1997 Alt. 720 m/ 1947’.61 N $104^{\circ} 03^{\prime} .32$ O/ Col. M. Sarmiento] (1F, EBCC); [Mexico, Jal-

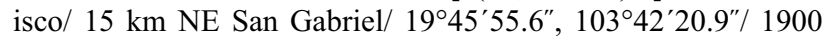
m 29-XI-2001] [trans. bosque/ encino-selva baja/ en Mimosa sp./ R.L. Westcott] (1F, EBCC); [Mexico: Jalisco/ $15 \mathrm{~km} \mathrm{NE}$ San Gabriel/ 1945'55.6"/ 103²2'20.9" 1900 m/ 29-XI-2001] [Ecotono bosq. encino-/ selva baja/ col. F.A. Noguera] (1M, EBCC); [MEX: JALISCO,/ 12-19 km NW of/ Hwy Jct 427-80/ 17-X-1996/ J.D. McCarty] (1M JMCC); [MEXICO: Morelos/ 4 km O Ajuchitlán/ 19-XI-1995/ Alt. $940 \mathrm{~m} / 18^{\circ} 27^{\prime} .632 \mathrm{~N}$ $99^{\circ} 00^{\prime} .125 \mathrm{O} / \mathrm{Col}$. F.A. Noguera] (1F, EBCC); [MEX. 5 mi. S./ Amacuzac, Mor./ IX-28-64] [E.G. Linsley/ Collector] [A.E. Michelbacher] (1M, IF, GHNC); [MEX. 5 mi. S./ Amacuzac, Mor./ IX-28-64] [E.G. Linsley/ Collector] [A.E. Michelbacher/ Collector] (2F, EMEC); [Cuernavaca/ Mexico/ XI-3, 1902] [Koebele/ Collection] (1M, CASC); [Cuernavaca/ Mexico/ XII-4, 1902] [Koebele/ Collection] (1F, CASC); [MORELOS, $2.5 \mathrm{~km} \mathrm{~N}, / 4 \mathrm{~km} \mathrm{~W}$ Huautla, Est./ CEAMISH, $18^{\circ} 28^{\prime} \mathrm{N} / 98^{\circ} 02$ W, 940 m, 7-/ vii.96 R.L. Westcott] [Beaten from/ ACACIA sp.] (1F, RLWE); [MEXICO: Morelos/ $2.5 \mathrm{~km} \mathrm{~N}, 4 \mathrm{~km} \mathrm{O}$ Huautla/ Est. CEAMISH Alt. $940 \mathrm{~m} /$ 9-VIII-1996 s/troncos/

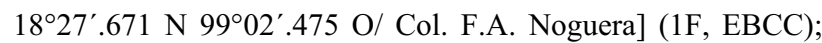
[MEXICO: Morelos/ $2.5 \mathrm{~km} \mathrm{~N}, 4 \mathrm{~km} \mathrm{O}$ Huautla/ Estación CEAMISH/ 10-VIII-1996 Alt. 940 m/ 18²7'.671 N 9902'.475 $\mathrm{O} /$ Col. C.A. Uribe] (1F, EBCC); [MEXICO: Morelos/ $2.5 \mathrm{~km}$ N, 4 km O Huautla/ Estación CEAMISH/ 7-IX-1996 Alt. 940 $\mathrm{m} / 18^{\circ} 27^{\prime} .671 \mathrm{~N} 99^{\circ} 02^{\prime} .475 \mathrm{O} / \mathrm{Col}$. F.A. Noguera] (1F, EBCC); [MEXICO: Morelos/ $2.5 \mathrm{~km} \mathrm{~N}, 4 \mathrm{~km}$ O Huautla/ Estación CEAMISH/ 7-IX-1996 Alt. 940 m/ 18²7'.671 N $99^{\circ} 02^{\prime} .475 /$ Col. E. Ramírez] (1F, EBCC).

Etymology. The specific epithet used for this new species is derived from the Greek form of the adjective "blue" (cyaneos) to denote the coloration of the tarsi.

Distribution. This species has been collected only from Mexico, the state and county records include the following: Colima: Campo Cuatro, \pm 18 km (air) NW Colima; Guerrero: Iguala; 16 km NW Iguala; 13 km NW Iguala; Cacahuamilpa; Michapa; 40.7 mi N Zumpango del Río; 1 km S Taxco; Jalisco: Autlán, Cerrito la capilla; $7 \mathrm{~km}$ NNE, $2 \mathrm{~km} \mathrm{SW}$ Autlán; $4 \mathrm{~km} \mathrm{SE}$ Cuautla; 8 km NW Ayutla; 6.6 km SO San Buenaventura; San Buenaventura; 4 km SO San Buenaventura; 15 km NE San Gabriel; Morelos: $5 \mathrm{mi} \mathrm{S}$ Amacuzac; $4 \mathrm{~km} \mathrm{O}$ Ajuchitlán; Cuernavaca; $2.5 \mathrm{~km} \mathrm{~N}, 4 \mathrm{~km} \mathrm{~W}$ Huautla, Estación CEAMISH.

Adult host plants. On Acacia sp., Conzattia multiflora, and Mimosa sp. (Fabaceae).

\section{Lampetis (Spinthoptera) dilaticollis (Waterhouse, 1882)}

(Figs 13, 44)

Psiloptera dilaticollis Waterhouse, 1882: 11; Kerremans, 1885: 133; Waterhouse, 1889: 173; Dugés, 1891: 5; Kerremans, 1892: 60; 1903: 94; 1910: 124; Kempers, 1923: 90 (wing venation); Cazier, 1951b: 43.

Psiloptera (Lampetis) dilaticollis; Obenberger, 1926: 165; Blackwelder, 1944: 310; Westcott et al., 1990: 230.

Lampetis (Spinthoptera) dilaticollis; Kurosawa, 1993: 580.

Diagnosis. Robust; ventral surface bluish black; punctures and impressions brassy-green or brassy-cupreous with short, recumbent, white setae; antennae black with violet and blue tinge; pronotum black with blue and violet tinge, along anterior margin to middle with a strong beadlike longitudinal depression, disc with impressed median channel extending from posterior margin to near anterior margin and with strong, broad depression at middle of posterior margin with blue and violet tinge, surface without punctures medially; elytra black, along lateral margins to apices with violet tinge, disc with scarcely impressed punctate striae; first ventrite feebly concave along midline, other ventrites convex.

Male redescription. Length 20.9-30.9 mm; width 7.5-11.9 mm. Head: Labrum black with brassy and blue tinge, with abundant small, shallow, confluent punctures; clypeus black with blue and brassy tinge, anterior margin concave, with scarce large, deep, confluent punctures toward margins; frons flattened, callosities with violet or blue tinge, surface with numerous large, deep, confluent punctures and strong callosities; vertex black with violet tinge, with few small, shallow, not confluent punctures; bases of mandibles black with violet tinge, with numerous large, deep, confluent punctures; maxillary palpi black with violet tinge. Pronotum: 2.0 times wider than long, widest near anterior margin; lateral margins moderately concave at base, expanded after middle and rounded to anterior angles, narrowest anteriorly; lateral margins carinate over two-thirds of the length; along anterior margin to middle with a strong longitudinal bead-like depression; anterior and posterior margins slightly bisinuate with weak and broad median lobe; posterior angles slightly acute; disc convex, with impressed median channel extending from posterior margin to near anterior margin and with strong, broad depression at middle of posterior margin with blue and violet tinge; surface without punctures medially; laterally with abundant large, deep, confluent punctures, and few weak callosities. Scutellum: black, small, oval. Elytra: apices weakly emarginate, outer and sutural angles slightly dentiform; disc convex with weakly impressed punctate striae; surface with a strong longitudinal impression along anterior margin, and many large, finely punctate interstrial impressions, these commonly confluent in transverse and oblique groupings and densely clothed with setae. Prosternum: disc convex; surface with abundant small, deep, confluent punctures laterally, with scarce punctures medially; prosternal process slightly convex, sulci with small, shallow, confluent punctures, apex bluntly rounded. Mesosternum: surface with numerous small, shallow, confluent punctures laterally, without punctures medially. Mesepisternum and mesepimeron: with few large, shallow punctures, sparse toward margins. Metasternum: flattened with numerous fine punctures medially, with fine setae; numerous large, deep, not confluent punctures laterally. Metacoxae: surface clothed with dense setae along posterior and external lateral margin; with abundant small, deep, confluent punctures at external lateral margin to middle, fewer punctures at middle; few fine, sparse punctures toward internal lateral margin. Femora: black, with violet tinge; with abundant small, not confluent 
punctures. Tibiae: violet with some blue tinge; with densely punctate, with small, shallow, confluent punctures. Tarsi: with violet and blue tinge. Abdomen: first ventrite flattened along midline; other ventrites convex; apex of last visible ventrite feebly rounded emarginated at middle; abdominal surface irregularly punctate with abundant small, shallow, confluent punctures. Male genitalia as in Fig. 44.

Female. Length $21.4-31.8 \mathrm{~mm}$; width $7.9-12.7 \mathrm{~mm}$. Differs from male as follows: apex of last visible ventrite rounded, in some specimens rounded with weak emargination at middle.

Variation. This species (50 males and 52 females examined) varies in the coloration; anterior margin and callosities of pronotum the usual violet to black; scutellum from black to black with blue tinge; setae white to yellowish-white.

Differential diagnosis. Lampetis dilaticollis is similar to L. drummondi and L. webbii. Lampetis drummondi entire surface is brassy-green, brassy-cupreous, or blue; elytral apices generally brassy-green or brassy-cupreous; pronotal lateral margins roundly converging anteriorly; elytral disc with punctate interstrial impressions commonly confluent in transverse or oblique groupings, striae feebly impressed; first ventrite without carina. Lampetis webbii dorsal surface is dark bluish-black with brassygreen punctures; ventral surface dark blue; elytral apices generally dark blue; pronotal lateral margins obliquely converging at anterior margin, disc moderately convex; elytral disc with punctate interstrial impressions usually isolated from each other, striae feebly impressed; first ventrite with midline concavity usually emarginate by smooth, broad carina.

Type material studied. Male lectotype desinated here: [Coll. R.I.Sc.N.B./ Mexique Villa Lerdo,/ Durango./ Höge.] [Biol. C. Amer./ Don/ Godman et Salvin] [Syntype] [Lectotype/ A.M. Corona des./ 2004] (ISNB). Paralectotypes: [Coll. R.I.Sc.N.B./ Mexique Villa Lerdo,/ Durango./ Höge.] [Biol. C. Amer./ Don/ Godman et Salvin] [Syntype] [Paralectotype/ A.M. Corona des./ 2004] (1F, ISNB); [Coll.R.I.Sc.N.B./ Mexique Koll. Dr. Frh.v.Hoscheck/ Villa Lerdo,/ Durango./ Höge.] [Syntype] [Paralectotype/ A.M. Corona des./ 2004] (1F, ISNB); [Coll. R.I.Sc.N.B./ Mexique Villa Lerdo,/ Durango.] [Syntype] [Paralectotype/ A.M. Corona des./ 2004] (1F, ISNB); [SYN-/ TYPE] [Sa. de/ S. Miguelito./ Dr. Palmer.] [Psiloptera/ dilaticollis/ (Type) Waterh.] [B.C.A., III./ Psiloptera/ dilaticollis] [Paralectotype/ A.M. Corona des./ 2004] (1F, BMNH); [SYN-/TYPE] [Sa. de/ S. Miguelito./ Dr. Palmer.] [B.C.A., III./ Psiloptera/ dilaticollis.] [Paralectotype/ A.M. Corona des./ 2004] (1M, 1F, BMNH); [SYN-/TYPE] [Hacienda de/ Bleados/ S. Luis Potosí./ Dr. Palmer.] [Psiloptera/ dilaticollis./ (Type) Waterh.] [Paralectotype/ A.M. Corona des./ 2004] (1F, BMNH).

Distribution. This species is widespread in Mexico. State and county records include the following: Aguascalientes: $5 \mathrm{mi} \mathrm{N}$ Rincón de Romos; 18.8 km E Troncoso, carr. Zacatecas-S.L.P.; Chihuahua: Conchos; 10 mi N Cd. Jiménez; 18 mi W Jiménez; $18 \mathrm{mi} \mathrm{N}, 7 \mathrm{mi}$ E Parral; Salaices; Coahuila: La Gloria, Monclova; $32 \mathrm{mi}$ E Paila; $14 \mathrm{mi} \mathrm{S}$ Paila; $37.5 \mathrm{mi} \mathrm{W}$ Paila; $7 \mathrm{mi} \mathrm{N}$ Parras; Oasis, NE Murilla, Hwy. 37; 77 mi W Saltillo; Durango: Reserva de la Biosfera, 65 km E Ceballos; Cuencamé; Yerbanís; Hwy. 45, 25 mi S Durango; 6 mi NE El Salto; $49 \mathrm{mi} \mathrm{N} \mathrm{La}$ Zarca; 10 mi S La Zarca; Villa Lerdo; Guanajuato: San Diego de la Unión; San Luis de la Paz; Hidalgo: 2.3 km S Cardonal, 1967 m; 15 mi NW Ixmiquilpan; 12 km S Ixmiquilpan; 2 km N Ixmiquilpan; Jalisco: $29 \mathrm{~km}$ NE Lagos de Moreno; Morelos: Malezas; Nuevo León: Hwy. 40, $14.3 \mathrm{mi}$ W Saltillo; Oaxaca: Miahuatlán; Querétaro: El Marqués Aztlán; Peña Blanca; Peñuelas; Tolimán, km 46 carr. Bernal-Tolimán; San Luis Potosí: Hacienda de Bledos; 29 mi SW San Luis Potosí; 12 km W Río Verde; Zacatecas: Zacatecas.

Adult host plants. On Acacia sp. (Fabaceae), Ephedra sp. (Gnetaceae), flower of Maytenus phyllantoides (Celastraceae), and Opuntia imbricata (Cactaceae) and Kocberlinia spinosa (Kocberliniaceae).

Phenology. Collected from January to November.

\section{Lampetis (Spinthoptera) drummondi (Laporte \& Gory, 1836)}

(Figs 14, 45, 70, 75, 80)

Buprestis drummondi Laporte \& Gory, 1836: 37.

Psiloptera drummondi; Waterhouse, 1882: 10; Kerremans, 1910: 130.

Dicerca woodhousei LeConte, 1852: 68.

Psiloptera woodhousei; LeConte, 1860: 193; Kerremans, 1910: 130.

Spinthoptera woodhousei; Casey, 1909: 74.

Psiloptera valens LeConte, 1858a: 66; Kerremans, 1910: 128.

Spinthoptera valens; Casey, 1909: 73.

Spinthoptera convexa Casey, 1909: 72 (preoccupied Laporte \& Gory, 1837).

Spinthoptera ocularis Casey, 1909: 73.

Psiloptera ocularis Kerremans, 1910: 125.

Spinthoptera parva Casey, 1909: 73.

Psiloptera caseyi Kerremans, 1910: 126 (replacement name for convexa Casey, 1909).

Psiloptera (Lampetis) drummondi; Nelson, 1986: 276; Nelson et al., 1996: 188.

Diagnosis. Dorsal and ventral surfaces brassy-green, brassy-cupreous, or blue, elytra apices generally brassygreen o brassy-cupreous; head and labrum brassy-green, blue callosities on vertex and brassy callosities on frons; antennae black with blue tinge basally; pronotum with lateral margins roundly converging anteriorly, surface moderately coarsely and rugosely punctate laterally; elytral apices weakly dentiform, disc convex with punctate impressions commonly confluent in transverse or oblique groupings, striae feebly impressed; first ventrite feebly concave along midline without carina. Male genitalia as in Fig. 45.

Distribution. From 418 males and 368 females examined, this species has been collected in Mexico and the USA State and county records in Mexico include the following: Chihuahua: 85 mi SE Juárez at Banderas; 8 mi S Gallege; 12 mi S Villa Ahumada; Coahuila: Nueva Rosita; Tamaulipas: Reynosa; Nuevo León: Campo Apodaca, $19 \mathrm{~km}$ NE de Monterrey; Monterrey; 5 mi NE Villa García; Vallecillo; V. de Santiago; Rancho Presa. In the USA: Arizona: Cochise; Maricopa; Colorado: Lincoln; Kansas: Barber; Ford; Gove; Meade; Riley; Louisiana: Alexandria; Forest Hill; Rapides Parish; Missouri: South West City; Nuevo Mexico: Chaves; Doña Ana; Eddy; Las Cruces; Luna; Roosevelt; Valencia; Oklahoma: Davis; Fort Sill; Grady; McClain; Murray; Texas: Archer; Brewster; Crosby; Edwards; Erath; Floyd; Hars; Hidalgo; Jeff Davis; Kinney; Oklahoma; Pecos; Presidio; Reeves; Terrell; Valverde; Ward; Wilbarger; Zapata. 
Adult host plants. On Acacia farnesiana, A. greggii, A. sp., Eysenhardtia texana, and Mimosa biuncifera (Fabaceae), Bumelia sp. (Sapotaceae), Celtis laevigata var. texana (Ulmaceae), Chilopsis linearis (Bignoniaceae), Diospyros texana (Ebenaceae), Erigonum effusum (Polygonaceae), Karwinskia humboldtiana (Rhamnaceae), Quercus gravesii (Fagaceae), Rhus virens (Anacardiaceae), Salix sp. (Salicaceae), Tamarix sp. and Tamarix gallica (Tamaricaceae), Zea mays (Gramineae), and cultivated cotton.

Phenology. Collected from February to December.

\section{Lampetis (Spinthoptera) geniculata Waterhouse, 1889}

(Figs 15, 46)

Psiloptera geniculata Waterhouse, 1889: 172; Kerremans, 1892: 61; 1903: 94; Obenberger, 1926: 166; Blackwelder, 1944:

311; Hołyński, 1988: 52.

Lampetis (Spinthoptera) geniculata; Kurosawa, 1993: 580.

Diagnosis. Dorsal surface greenish and bluish black, punctures cupreous margined with red-coppery; ventral surface red-coppery with brassy tinge; punctures with short, recumbent, white setae; first antennal segment redcoppery, the rest of segments black with greenish tinge; pronotal surface with impunctate areas, and scarce large, deep, sparse punctures, along lateral margins with a weak longitudinal depression, with abundant small, confluent punctures; elytral disc with weakly impressed punctate striae; and first ventrite concave along midline, ventrite 2 slightly concave.

Male redescription. Length 11.9-22.3 mm; width 4.0-8.5 mm. Head: Labrum bright red-coppery, with few shallow, not confluent punctures; clypeus bright redcoppery, anterior margin concave, with scarce small, shallow punctures; frons red-coppery, callosities with greenish tinge, flattened, with few large, deep punctures, with few callosities, along margin of the eyes with abundant small punctures with abundant setae; vertex redcoppery laterally, greenish black medially, with few small, deep punctures; mandibles red-coppery with greenish tinge on bases, with large, deep, confluent punctures; maxillary palpi bright green with cupreous tinge. Pronotum: 1.6 times wider than long; widest at middle; lateral margins slightly concave near base, slightly expanded at middle, then obliquely converging to anterior angles, narrowest anteriorly; lateral margins discontinuously carinate at middle toward base; anterior margin scarcely bisinuate with weak lobe and posterior margin slightly bisinuate, with weak, broad median lobe; posterior angles slightly acute; disc moderately convex; flattened in midline toward base; surface with large, deep, sparse punctures medially, with impunctate areas, toward lateral margins with few more confluent punctures; along lateral margins with a slight longitudinal depression, with abundant small, confluent punctures; along anterior margin toward middle with a line of small, deep, beadlike confluent punctures. Scutellum: red-coppery with greenish tinge, slightly transversely oval. Elytra: apices obliquely emarginate, with abundant setae; outer angle slightly more dentiform than sutural angle; disc moderately convex, with weakly impressed punctate striae; surface with few impressions at anterior margin, and many small finely punctate interstrial impressions, usually isolated from each other, and clothed with setae; toward lateral margins these impressions more numerous and commonly confluent in transverse and oblique groupings, with few small callosities. Prosternum: disc moderately convex, with numerous small, deep punctures laterally, scarce punctures medially, and small, deep, confluent punctures along anterior margin; prosternal process slightly convex, sulci with few small, shallow punctures; apex bluntly rounded. Mesosternum: without punctures medially, but with few small, deep, confluent punctures laterally. Metasternum: surface flattened, finely punctate and clothed with fine setae medially; with numerous large, deep, not confluent punctures laterally. Metacoxae: surface with abundant large, deep, confluent punctures medially; toward external lateral margin with abundant small, confluent punctures; but toward internal lateral margin with scarce small, shallow, not confluent punctures. Femora: red-coppery with greenish and bluish tinge at base, with small, shallow, sparse punctures. Tibiae: surface black with violet tinge, punctures brassy margined with bright green tinge. Tarsi: bright green with bluish and violet tinge. Abdomen: surface red-coppery with brassy tinge, some reliefs greenish black; first ventrite concave along midline, wide concavity finely punctate bordered by slight, impunctate carina; ventrite 2 slightly concave; ventrites 3-5 convex; apex of last visible ventrite feebly rounded and emarginate at middle; abdominal surface irregularly punctate, with abundant small, shallow, confluent punctures. Male genitalia as in Fig. 46.

Female. Length 13.9-27.3 mm; width 4.6-10.4 mm.

Variation. This species (35 males and 57 females examined) varies in the coloration; dorsal surface with the usual greenish and bluish black with cupreous punctures margined with red-coppery to black with punctures bright green margined with brassy; ventral surface red-coppery with brassy tinge to cupreous or black; maxillary palpi bright green with blue tinge to bright green with brassy tinge; scutellum red-coppery with greenish tinge to black with reddish-coppery and greenish tinge; tibiae black with violet tinge to black with violet and cupreous tinge.

Differential diagnosis. Lampetis geniculata is similar to L. cupreopunctata. Lampetis cupreopunctata is black above, impressions and punctures cupreous, ventral surface cupreous; pronotum with weak midline impression extending from base almost to anterior margin; elytra widest at base, narrowing rather gradually to apex, disc with striae moderately impressed.

Type material studied. Male lectotype designated here: [SYN-/ TYPE] [Temax,/ N. Yucatan,/ Gaumer.] [B.C.A., III./ Psiloptera/ geniculata.] [Lectotype/ A.M. Corona des./ 2004] (BMNH). Paralectotypes: same label as male lectotype [Paralectotype/ A.M. Corona des./ 2004] (1M, 4F, BMNH); [SYN-/ TYPE] [Temax,/ N. Yucatan,/ Gaumer.] [Psiloptera/ geniculata,/ (Type) Waterh.] [Paralectotype/ A.M. Corona des./ 2004] (1F, BMNH); [Coll.R.I.Sc.N.B./ Mexique Temax,/ N. Yucatan/ Gaumer.] [Paratype] [Paralectotype/ A.M. Corona des./ 2004] (1F, ISNB). 
Distribution. This species has been collected in southern Guatemala, Honduras and Mexico. State and county records in Guatemala include the following: Petén: Tikal Mayan Ruins. In Mexico: Chiapas: Musté; Quintana Roo: Cancún; 20 km SW Cancún; $20 \mathrm{~km}$ N Carrillo Puerto; 17 km NW Felipe Carrillo Puerto; 19 km N Carrillo Puerto; 39 km NW Felipe Carrillo Puerto; 17 km N Felipe Carrillo Puerto; 17 km NE Felipe Carrillo Puerto; $60 \mathrm{~km} \mathrm{~N}$ Felipe Carrillo Puerto; Chetumal; $1 \mathrm{~km} \mathrm{~S}$ José Pino Suárez; 15 km S Morocoy; Playa del Carmen; 20 km W Puerto Morelos; 26 km SE Valle Hermoso; Yucatán: Chichén Itza; Temax, N Yucatán; Tinum, Pisté; Pisté, 120 km E Mérida, nr. Chichén Itza; $22 \mathrm{~km}$ NE Pisté; $13 \mathrm{mi} \mathrm{E}$ Valladolid; $1 \mathrm{~km} \mathrm{~S}$ Xcalacoop; 0.3 km E Xcalacoop; X-Can; Nuevo X-Can.

Phenology. Collected from May to October.

\section{Lampetis (Spinthoptera) granulifera (Laporte \& Gory, 1837)}

(Figs 16, 47)

Buprestis granulifera Laporte \& Gory, 1837: 83.

Psiloptera granulifera; Gemminger \& Harold, 1869: 1367; Saunders, 1871: 24; Waterhouse, 1882: 8; Kerremans, 1892: 61; 1903: 94.

Psiloptera (Lampetis) granulifera; Obenberger, 1926: 166; Blackwelder, 1944: 311.

Lampetis (Spinthoptera) granulifera; Kurosawa, 1993: 580.

Diagnosis. Dorsal surface bright green with reddish and yellowish tinge medially, bright green laterally; ventral surface reddish-green medially, red-coppery with yellowish tinge laterally; punctures bright green with short, recumbent, white setae; first antennal segment bright green, the other segments dark-brown with bright green basally; elytral disc with slightly impressed punctate striae and toward or after the second striae with many large, punctate, yellowish interstrial impressions; first ventrite slightly concave along midline, ventrite 2 flattened along midline.

Male redescription. Length 16.5-22.9 mm; width 5.7-8.1 mm. Head: Labrum bright green with yellowish tinge, with few small, shallow, confluent punctures, with few setae; clypeus bright green with yellowish and cupreous tinge, anterior margin emarginate at midline, with numerous small, deep, confluent punctures at margins, without punctures medially; frons bright green with brassy and cupreous tinge, punctures bluish-green, sinuate with abundant small, deep, confluent punctures and small callosities; vertex bright green with yellowish and cupreous tinge; mandibles bright green, with numerous small, deep, confluent punctures on bases; maxillary palpi bright green. Pronotum: 1.5 times wider than long; lateral margins slightly concave before base, slightly expanded and rounded at middle, then slightly obliquely converging to anterior angles; narrowest anteriorly; lateral margins slightly carinate at middle; anterior margin weakly bisinuate with weak median lobe; posterior margin slightly bisinuate with slight, broad median lobe; posterior angles slightly acute; disc moderately convex, slightly flattened in midline toward base; surface with few small, deep, not confluent punctures medially, laterally with abundant confluent punctures, and few weak callosities. Scutellum: reddish-green, small, rounded. Elytra: apices obliquely emarginate, outer and sutural angles dentiform; disc moderately convex, with slightly impressed punctate striae; surface with few small impressions and after the second striae with many large finely punctate, yellowish interstrial impressions, more numerous toward lateral margins, these isolated each other and with numerous fine setae; numerous small callosities laterally. Prosternum: disc moderately convex, with numerous small, deep, confluent punctures laterally, scarce small, deep punctures medially; prosternal process flattened, sulci with small, deep punctures; apex bluntly rounded. Mesosternum: without punctures medially, but with few small, deep punctures laterally. Mesepisternum and mesepimeron: with few shallow, sparse punctures. Metasternum: surface flattened, with few fine punctures, with fine setae medially; abundant, small, deep, confluent punctures laterally. Metacoxae: at middle toward external lateral margin with numerous small, confluent punctures and weak callosities, with few setae; toward internal lateral margin with scarce fine, sparse punctures. Femora: surface reddish-green with yellowish tinge medially, dark green at base; with few small, deep, not confluent punctures. Tibiae: surface bright green, with yellowish tinge; abundant shallow, confluent punctures. Tarsi: dark green, with bluish tinge. Abdomen: first ventrite slightly concave along midline, wide concavity with numerous small, shallow punctures and bordered by slight, impunctate carina; ventrite 2 flattened along midline; ventrites 3-5 convex; apex of last visible ventrite feebly rounded with emargination at middle; abdominal surface moderately and irregularly punctate. Male genitalia as in figure 47 .

Female. Length 17.8-27.4 mm; width 6.4-10.1 mm.

Variation. This species (32 males and 48 females examined) varies in the coloration; the usual reddishgreen medially, red-coppery with yellowish tinge laterally to bright green with reddish and yellowish tinge or redcoppery with yellowish tinge below; punctures bright green to bluish green; first antennal segment bright green to cupreous; labrum and clypeus bright green with yellowish tinge to bright green or cupreous; frons bright green to bright green with yellowish and cupreous tinge; bases of mandibles bright green to red-coppery; scutellum reddish-green to bright green; pronotum bright green laterally, bright green with reddish and yellowish tinge medially to red-coppery; elytra impressions bright green margined with brassy to bright green margined with cupreous; femora reddish-green with yellowish tinge to bright green with yellowish tinge to cupreous with yellowish tinge; tibiae bright green with yellowish tinge to bright green, or bright green with yellowish and cupreous tinge; tarsi dark green with bluish tinge to bluish green, or bright green with yellowish tinge.

Differential diagnosis. Lampetis granulifera is similar to L. monilis. Lampetis monilis is slender; ventral surface reddish-green medially, laterally red-coppery; punctures and impressions bright green; pronotum bright green, lateral margins subparallel at base, slightly expanded at middle, then obliquely converging to anterior angles; elytral surface bright green with reddish tinge at middle, reliefs reddish and greenish, with strongly impressed punctate 
striae, generally after the four striae toward lateral margins with few finely punctate, interstrial impressions.

Type material studied. Female lectotype designated here: [Granulifera/ Gory/ Brésil/ Type] [Lectotype/ A.M. Corona des./ 2004] (MNHN). Female Paralectotype: same label as female lectotype [Paralectotype/ A.M. Corona des./ 2004] (MNHN).

Distribution. This species has been found in Brazil (type specimens without more detailed data), Guatemala and Mexico. State and county records include the following: in Guatemala: Quetzaltenango: Hacienda El Reposo. In Mexico: Chiapas: 10 mi NW Arriaga, nr. Río Las Arenas, Chiapa; $20 \mathrm{~km} \mathrm{E}$ Cintalapa; 2 mi E Rizo de Oro; Oaxaca: 48 mi E La Ventosa; 10 mi SE Tapanatepec; Istmo de Tehuantepec; Puebla: Atlixco; San Luis Potosí: 15 mi N Ciudad Valles; Veracruz: vic. Barranca de Coyoapa, Tejería, Teocelo; $3 \mathrm{~km} \mathrm{~S}$ Carrizal; Catemaco Lake; Santa Cotaxtla; 14 mi Cuitláhuac; 8 mi W Palma Sola; 6 mi N Rinconada; Volcán San Martín; San Pedro de Soteapan; Hwy. 145, 8 mi S Tinaja; 41 km SE Xalapa.

Adult host plant. On Mimosa sp. (Fabaceae).

Phenology. Collected from July to November.

\section{Lampetis (Spinthoptera) guildini (Laporte \& Gory, 1836)}

(Figs 17, 48, 67, 73)

Buprestis guildini Laporte \& Gory, 1836: 41.

Psiloptera guildingi; Germminger \& Harold, 1869: 1367; Kerremans, 1892: 61.

Psiloptera guildingii; Saunders, 1871: 24; Waterhouse, 1896: 104.

Psiloptera guildini; Kerremans, 1903: 101; 1910: 144; Fisher, 1925: 50.

Psiloptera (Lampetis) guildini; Obenberger, 1926: 166; Blackwelder, 1944: 311.

Lampetis (Spinthoptera) guildini; Kurosawa, 1993: 580.

Diagnosis. Dorsal surface bluish-green, sometimes dark-green, impressions blue or violet; ventral surface dark green or bluish-green, some punctures blue; punctures with short, recumbent, white setae; antennae bluishgreen; elytral disc moderately convex with weakly impressed punctate striae, surface with few small impressions along base and many finely punctate, interstrial impressions, usually isolated from each other; abdomen with first ventrite concave along midline, this concavity bordered by slight and impunctate carina, ventrite 2 flattened in midline, ventrites 3-5 convex.

Male redescription. Length 14.2-18.4 mm; width 4.9-6.8 mm. Head: Labrum dark green, with few small, shallow, not confluent punctures, surface granulose; clypeus dark green, with blue tinge, anterior margin slightly concave, with numerous small, deep, confluent punctures; frons blue or bluish-green, flattened, surface with numerous large, deep, confluent punctures forming many strong callosities, along margins of eyes with few large, deep, confluent punctures; vertex bluish-green or sometimes dark green, with large, deep, sparse punctures; bases of mandibles dark green and bluish-green, rugosely punctate, with abundant large, deep, confluent punctures; maxillary palpi dark green and bluish-green, with abundant setae. Pronotum: 1.5 times wider than long, widest before posterior margin; lateral margins subparallel at base, slightly expanded before middle, then obliquely converging to anterior angles, narrowest anteriorly; lateral margins slightly carinate at middle to base; anterior margin slightly bisinuate with weak median lobe; posterior margin bisinuate with weak, broad median lobe; posterior angles acute; disc moderately convex, slightly flattened in midline toward posterior margin; along midline with scarce small, deep punctures, with few small, deep punctures medially, becoming more abundant laterally with some callosities. Scutellum: blue or bluish-green, rounded and finely granulose. Elytra: apices obliquely emarginate, outer angle dentiform; disc moderately convex with feebly impressed punctate striae; surface with few small impressions along anterior margin and many finely punctate, interstrial impressions, usually isolated from each other, and with few setae; laterally with punctures deeper and more confluent, and weak callosities. Prosternum: disc convex, surface with abundant large, deep, confluent punctures laterally, becoming sparse medially, along anterior margin with abundant small, deep, confluent punctures; prosternal process slightly convex, with a line of small, deep punctures medially, sulci with abundant fine, confluent punctures, apex slightly rounded. Mesosternum: surface with few small, deep, confluent punctures laterally, without punctures medially. Mesepisternum and Mesepimeron: dark green or bluish-green; with numerous small, shallow, not confluent punctures, with abundant setae. Metasternum: some punctures blue; flattened with scarce small, shallow punctures medially; laterally numerous large, deep, not confluent punctures. Metacoxae: some punctures blue; surface with numerous large, deep, confluent punctures at middle; toward external lateral margin with abundant small, shallow, confluent punctures; scarce small, deep punctures at internal lateral margin. Femora: dark green or bluish green; with numerous large, deep punctures. Tibiae: dark green or bluish green; surface with numerous small, shallow, not confluent punctures. Tarsi: dark green or bluish-green, sometimes with violet tinge. Abdomen: with first ventrite concave along midline, this concavity with few small, shallow punctures, and bordered by slight, impunctate carina; ventrite 2 flattened in midline; ventrites 3-5 convex; apex of last visible ventrite subtruncate; abdominal surface coarsely and irregularly punctate laterally, punctures small, shallow, confluent, and irregularly shaped; medially with few small, shallow, not confluent punctures. Male genitalia as in Fig. 48.

Female. Length 15.3-27.7 mm; width 5.6-10.9 mm. Females are more robust in body shape than males.

Variation. This species ( 8 males and 13 females examined) varies in the coloration; dorsal and ventral surfaces with the usual bluish-green to dark or bright green; impressions blue or violet to bright green.

Differential diagnosis. This species can be readily distinguished from any other species of this genus by the uniform blue or bluish green above and by the absence of longitudinal and transverse impressions on the pronotum; elytral lateral margins without longitudinal depression; 
prosternal process bisulcate laterally and sulcate at middle.

Distribution. This species has been collected only in Grenada and Grenadines. State and county records include the following: in Grenada: Saint George: Grand Anse; Mount Hartman National Park; Point Salines; Airport; Saint Andrew: Pearls; Airport. In Grenadines: Prune Island; St. Vincent; Tobago Cays.

Adult host plant. Bauhinia aculeata (Leguminosae).

Phenology. Collected from January to December.

\section{Lampetis (Spinthoptera) hirtomaculata (Herbst, 1801)}

(Figs 20, 49, 79)

Buprestis hirtomaculata Herbst, 1801: 84; Laporte \& Gory, 1836: 38.

Psiloptera hirtomaculata Schönherr, 1817: 216; Dejean, 1833: 76; 1836: 86; Mannerheim, 1837: 49; Lacordaire, 1857: 28; Gemminger \& Harold, 1869: 1366; Saunders, 1871: 24; Waterhouse, 1882: 10; 1889: 173; Kerremans, 1892: 61; 1896: 23; 1903: 94; Casey, 1909: 77; Kerremans, 1910: 123; Obenberger, 1937: 100.

Lampetis (Spinthoptera) insularis Casey, 1909: 76 (new synonymy).

Psiloptera insularis; Kerremans, 1910: 138.

Psiloptera (Lampetis) hirtomaculata; Obenberger, 1926: 166; Blackwelder, 1944: 311.

Psiloptera (Lampetis) insularis; Obenberger, 1926: 167; Blackwelder, 1944: 311.

Lampetis (Spinthoptera) insularis; Kurosawa, 1993: 580.

Diagnosis. Punctures and impressions bright green; punctures with short, recumbent, yellowish-white setae; head dark bronze with olive and purple tinge; antennae black with olive and purple tinge; pronotum dark bronze with metallic reddish tinge, along anterior margin to midline with a slight depression with abundant small, confluent punctures; elytra dark bronze with purple and brassy-green tinge, with four transversal impressions from lateral margins to middle, the last one smaller than the rest; metasternum and metacoxae with reddish tinge laterally; abdomen metallic red with dark bronze tinge.

Female holotype redescription. Total body length $22.7 \mathrm{~mm}$; width $8.7 \mathrm{~mm}$. Head: Labrum bright green, with numerous small, shallow, confluent punctures; clypeus bright green, anterior margin slightly concave, with numerous small, deep, confluent punctures; frons slightly sinuate, with numerous small, deep, confluent punctures and numerous small callosities, surface with few setae, along margin of eyes densely punctate and with abundant setae; vertex with few small, shallow, sparse punctures; bases of mandibles bright green with reddish tinge at margins, with numerous small, deep, confluent punctures; maxillary palpi reddish-brown. Pronotum: 2.0 times wider than long, widest at base and before middle; lateral margins slightly concave before base, expanded before middle and then obliquely converging to anterior angles; narrowest anteriorly; lateral margins carinate at middle to base; anterior and posterior margins slightly bisinuate with weak and broad median lobe; posterior angles slightly acute; disc moderately convex, flattened in midline toward posterior margin; surface with numerous small, confluent punctures near anterior margin, less confluent at posterior margin medially; abun- dant punctures laterally, forming few and weak callosities; along anterior margin to midline with a slight line of abundant punctures. Scutellum: dark bronze with olive and purple tinge, small, transversely oval at base. Elytra: apices obliquely emarginate, outer angles dentiform; disc convex, with strongly impressed punctate striae, these striae with fine punctures at middle; small, deep, confluent punctures basally and laterally; surface with numerous impressions along anterior margin, and with four transversal impressions from lateral margins to middle, the last one smaller than the rest; without interstrial impressions; impressions clothed with setae. Prosternum: metallic red medially, bronze laterally; disc convex; surface with numerous small, deep, not confluent punctures laterally, with scarce punctures at middle; prosternal process metallic red, flattened, sulci with fine, confluent punctures, with few setae; apex bluntly rounded. Mesosternum: metallic red; surface with few small, deep punctures laterally, without punctures medially. Mesepisternum and mesepimeron: dark bronze with reddish tinge; with numerous small, shallow, sparse punctures. Metasternum: flattened, with few fine punctures medially, with fine setae; laterally with numerous small, deep, confluent punctures. Metacoxae: with scarce small, shallow punctures at internal lateral margin; abundant confluent punctures at middle to external lateral margin. Femora: dark bronze with reddish tinge; punctures bright green; with numerous small, deep punctures. Tibiae: dark bronze with purple tinge, punctures bright green; with numerous small, shallow, not confluent punctures. Tarsi: dark bronze with purple tinge. Abdomen: first ventrite concave along midline, this concavity is narrow and bordered with wide, impunctate carina, and with few fine, sparse punctures, with fine setae; other ventrites convex; apex of last visible ventrite rounded; abdominal surface with abundant small, shallow, confluent, irregular punctures.

Male. Length 15.7-28.5 mm; width 5.5-10.4 mm. Male genitalia as in Fig. 49.

Variation. Female body shape: length 19.7-34.0 mm; width 7.5-14.2 $\mathrm{mm}$. This species varies in the size of elytral transversal impressions, in some specimens these impressions with or without yellowish pulverulence; and coloration: elytral surface the usual dark bronze with purple and brassy-green tinge to bright green medially and purple laterally; femora and tibiae from dark bronze with purplish tinge to bright green with reddish or purplish tinge.

Differential diagnosis. Lampetis hirtomaculata looks like to L. srdinkoana. Lampetis srdinkoana entire surface is reddish brown with golden green tinge; punctures bright green margined with golden green; antennae dark brown with golden green tinge; pronotum and elytra with a depression along lateral margins; first and second ventrites slightly concave along midline.

Type material studied. Buprestis hirtomaculata: Female holotype: [13606] [hirtomacula-/ ta/ Hbst./ Am. meridional] (ZMHB). Lampetis (Spinthoptera) insularis: Female holotype: [Taboga Is./ B y Panama] [CASEY/ hequest/ 1925] [TYPE USNM/ 35730] [insularis/ Cas.] (USNM). 
Distribution. From 15 males and 20 females examined, this species has been collected in Panama and Venezuela. State and county records include the following: in Panama: Pearl Island: San José; Province Panamá: Ancon; Barro Colorado; Old Panama; Taboga Island. In Venezuela: Aragua: Casa Blanca; Cata; El Limón; La Victoria; Maracay; Carabobo: Valencia; Cojedes: Pilancones; Distrito Federal: Caracas; Falcón: San Juan de los Cayos; Santa María; Guarico: Chaguaramal; Las Mercedes; Lara: Humocaro; Miranda: Machurucuto; Monagas: Bolivar; Tachira: Bramon; Zulia: Las Palmeras.

Adult host plants. Citrus sinensis (Rutaceae), Coffea sp. (Rubiaceae), Psidium guajava (Myrtaceae), and Zea mays (Gramineae).

Phenology. Collected from January to December.

\section{Lampetis (Spinthoptera) hondurensis sp. $\mathbf{n}$.}

(Figs 19, 50)

Diagnosis. Entire surface dark brown with bronze and purplish tinge, punctures brassy margined with purple; punctures with short, recumbent, white setae; antennae black with bronze tinge; elytral disc moderately convex, with moderately impressed punctate striae, with scarce impressions along anterior margin and few punctate interstrial impressions, along lateral margins these impressions are more numerous and larger than medially, usuallly 7-9 impressions; first ventrite slightly concave along midline, ventrite 2 flattened.

Male description. Length 18.1-24.9 mm; width 6.1-9.0 mm. Head: dark brown with bronze and purplish tinge; punctures brassy; labrum granulose, dark brown with brassy and purplish tinge, with few small, shallow punctures; clypeus anterior margin concave, without punctures medially, with numerous small, deep, confluent punctures laterally; frons slightly sinuate, coarsely and rugosely punctate with abundant small, deep, confluent punctures and numerous small callosities; vertex with numerous small, shallow, not confluent punctures; bases of mandibles with numerous small, deep, confluent punctures; maxillary palpi dark brown with purplish and bronze tinge. Pronotum: 1.5 times wider than long, widest near base; lateral margins subparallel before base, slightly expanded and rounded before middle and then slightly obliquely converging to anterior angles; narrowest anteriorly; lateral margins carinate at middle to base; along anterior margin to midline with a slight line of fine, deep, confluent punctures; anterior and posterior margins weakly bisinuate with weak median lobe; posterior angles slightly acute; disc convex, flattened in midline toward base; surface with numerous small, deep, sparse punctures, with impunctate areas medially; more numerous confluent punctures laterally, with few weak callosities. Scutellum: dark brown with purplish and bronze tinge, small, puntiform. Elytra: apices obliquely emarginate, outer and sutural angles dentiform; disc moderately convex, with moderately impressed punctate striae, these striae with small, shallow, confluent punctures, larger basally than apically, five striae visible; surface with scarce impressions along base and few small, finely punctate, interstrial impressions, these isolated from each other; along lateral margins these impressions are more numerous and larger than medially, usuallly 7-9 impres- sions. Prosternum: disc moderately convex; anterior margin weakly bisinuate; surface with abundant small, deep, confluent punctures laterally, with weak callosities; with scarce punctures medially; prosternal process flattened; sulci with small, deep, confluent punctures with numerous semierect setae, apex bluntly rounded. Mesosternum: surface with numerous small, deep, confluent punctures laterally, without punctures medially. Mesepisternum and mesepimeron: with few small, shallow, sparse punctures. Metasternum: flattened; with few fine punctures medially, with fine setae; numerous small, deep, not confluent punctures laterally. Metacoxae: with small, shallow, sparse punctures at internal lateral margin; numerous confluent at middle to external lateral margin. Femora: dark brown with bronze and purplish tinge; with numerous small, deep, confluent punctures. Tibiae: dark brown with bronze and purplish tinge; densely punctate, with small, shallow, confluent punctures. Tarsi: bronze with purplish tinge. Abdomen: first ventrite slightly concave along midline, this concavity narrow and bordered with slight, impunctate carina, and with numerous fine punctures; ventrite 2 flattened; other ventrites convex; apex of last visible ventrite feebly rounded emarginated at middle; abdominal surface with abundant small, shallow, confluent, irregularly shaped punctures. Male genitalia as in Fig. 50.

Female. Length 18.3-22.5 mm; width 6.3-7.8 mm.

Variation. This species varies in the coloration: the usual dark brown with bronze and purplish tinge to bronze with purplish tinge below; punctures from brassy margined with purple to brassy margined with bronze; tarsi from bronze with purplish tinge to dark brown with purplish and bluish tinge.

Differential diagnosis. Lampetis hondurensis sp. n. is similar to L. simplex. Lampetis simplex dorsal surface is black; ventral surface bright red medially, black with red tinge laterally; punctures cupreous margined with red; first antennal segment red, the rest black with reddish tinge; pronotal lateral margins subparallel at base, weakly expanded and rounded at middle, then slightly and obliquely converging to anterior angles; elytral disc with strongly impressed punctate striae, fifth interval toward lateral margins with few small punctures; first ventrite feebly concave along midline.

Type material. Male holotype: [HONDURAS, Cho. 982 m./ $1 \mathrm{~km}$ W. San Marcos de/ Colon, July 23, 1977/ O'Briens \& Marshall] (RLWE). 13(9M, 4F) Paratypes: [HONDURAS, Cho. 982 m./ 1 km W. San Marcos de/ Colon, July 23, 1977/ O'Briens \& Marshall] (3M, 1F, RLWE); [HONDURAS, El Par./ El Zamorano/ 27-VII-1977/ C.W. O'BRIEN] (1M, RLWE); [HONDURAS - Escuela/ Agricola Panamericana/ June $201967 /$ J.S. Packer] (1M, EMUS); [HONDURAS, Comay./ $1 \mathrm{~km}$ W San Marcos/ de Colon, 24-VII-77/ O'Brien \& Marshall] (2M, RLWE); [HONDURAS/ Zamorano] [Jan. 19 19??/ Adam/ Oseguera] (1M, USNM); [HOND. El Paraiso/ $17 \mathrm{~km}$. NW Jacaleapa/ 12 Oct. 1993/ R. Turnbow] (2F, GHNC); [San Agustin/ San Salvador/ S. Calderon] [On/ Albizzia/ molucana] (1F, USNM); [Poza Azul/ $1 \mathrm{~km}$ W El Panameño/ Depto. San Vicente/ El Salvador VI 6 1979] [RD Cave/ colr] (1M, CLBC).

Etymology. This species is named after the country of Honduras, where the specimens were collected. 
Distribution. This species has been found from El Salvador and Honduras. State and county include the following: in El Salvador: San Vicente: Poza Azul, 1 km W El Panameño; San Salvador: San Agustin. In Honduras: Choluteca: $1 \mathrm{~km}$ W San Marcos de Colon; El Paraíso; El Zamorano; 17 km NW Jacaleapa.

Adult host plant. Albizzia molucana (Fabaceae).

\section{Lampetis (Spinthoptera) lesnei (Kerremans, 1910)}

(Fig. 18)

Psiloptera lesnei Kerremans, 1910: 84.

Psiloptera (Lampetis) lesnei; Obenberger, 1926: 167; Blackwelder, 1944: 311.

Lampetis (Spinthoptera) lesnei; Kurosawa, 1993: 580.

Diagnosis. Dorsal surface lead-green with dark blue tinge; ventral surface lead-green, with dark blue and purple tinge; punctures with short, recumbent, white setae; antennae dark-blue; pronotal surface lead-green with purple tinge, punctures lead-green, and irregularly punctate; elytral surface with strongly impressed punctate striae, along lateral margins with narrow, longitudinal depressions; first ventrite slightly concave along midline, this concavity is bordered by narrow and impunctate carina, ventrites $2-5$ convex.

Female holotype redescription. Total body length $24.0 \mathrm{~mm}$; width $8.0 \mathrm{~mm}$. Head: Punctures purple with few setae; labrum lead-green, with few small, shallow punctures; clypeus lead-green with purple tinge, anterior margin emarginate, with few punctures at margins, scarce punctures medially; frons lead-green with purple tinge, sinuate, with numerous small, deep, confluent punctures and numerous small callosities; vertex lead-green with purple tinge, with numerous small, shallow, not confluent punctures; bases of mandibles dark-blue, with few large, deep punctures; maxillary palpi dark-blue. Pronotum: 1.6 times wider than long; widest at base; lateral margins subparallel at base, slightly expanded at middle and rounded to anterior angles, narrowest apically; lateral margins discontinuously carinate at middle to base; anterior and posterior margins slightly bisinuate, with weak median lobe; posterior angles rounded; disc moderately convex, slightly flattened along midline toward base; surface irregularly punctate, with abundant large, deep, confluent punctures, but more confluent laterally with callosities; along lateral margins with a depression, this with numerous small, confluent punctures. Scutellum: leadgreen with blue and purple tinge, punctiform. Elytra: apices weakly and obliquely emarginate; outer angle dentiform; disc moderately convex, with strongly impressed punctate striae; the striae formed by large, deep, confluent punctures; surface with few transverse impressions basally, and without punctures between striae; along lateral margins with a narrow, longitudinal depression, this with small, confluent punctures. Prosternum: disc moderately convex, with numerous large, deep, confluent punctures laterally, with weak callosities; numerous small, confluent punctures medially; prosternal process flattened, sulci with large, deep, confluent punctures, and numerous setae, apex bluntly rounded. Mesosternum: surface without punctures medially, but with few large, deep punctures laterally. Mesepimeron and mesepisternum: with scarce large, shallow punctures, and scarce setae. Metasternum: surface flattened, with few fine, not confluent punctures, and clothed with fine setae medially; laterally with numerous large, deep, not confluent punctures, with some impunctate areas. Metacoxae: with numerous large, not confluent punctures and weak callosities medially; toward external and internal lateral margins with few small, shallow punctures; along posterior margin to middle with numerous small, confluent punctures and numerous setae. Femora: surface lead-green, with dark blue and purple tinge. Tibiae: surface leadgreen, with dark blue and purple tinge. Tarsi: lead-green with blue and purple tinge. Abdomen: first ventrite slightly concave along midline, with numerous small, confluent punctures, and numerous setae, and this concavity bordered by narrow and impunctate carina; ventrites 2-5 convex; apex of last visible ventrite rounded; abdominal surface densely and discontinuously punctate, with abundant small, shallow, confluent punctures.

Male. Unknown.

Differential diagnosis. Lampetis lesnei looks like $L$. mexicana. Lampetis mexicana is moderately robust; pronotum dark bluish-green, punctures metallic green; elytra dark bluish-green with violet tinge, punctures bright green; disc with slightly impressed punctate striae, first three striae clearly visible, surface with many finely punctate, large interstrial impressions; first ventrite slightly concave along midline, concavity bordered by weak, impunctate carina.

Type material studied. Female holotype: [MUSEUM PARIS/ COSTA-RICA/ DE LAFON 1884] [PSILOPTERA/ LESNEI/ Kerrem. TYPE] (MNHN).

Distribution. Known only from the type locality: Costa Rica.

\section{Lampetis (Spinthoptera) mexicana Théry, 1923}

(Figs 21, 51)

Lampetis mexicana Théry, 1923: 250.

Psiloptera (Lampetis) mexicana; Obenberger, 1926: 167; Blackwelder, 1944: 311.

Lampetis (Spinthoptera) mexicana; Kurosawa, 1993: 580.

Diagnosis. Ventral surface metallic green medially, bluish-green laterally; punctures and impressions bright green; punctures with short, recumbent, white setae; pronotum dark bluish-green, disc moderately convex, surface with abundant small, deep, confluent punctures, and some impunctate areas; elytra dark bluish-green with violet tinge, punctures bright green, disc with slightly impressed punctate striae, first three striae visible, surface with many finely punctate, large, interstrial impressions; first ventrite slightly concave along midline, concavity bordered by weak, impunctate carina, ventrites $2-5$ convex.

Female holotype redescription. Total body length $27.0 \mathrm{~mm}$; width $10.0 \mathrm{~mm}$. Head: Labrum bright green, with few small, shallow, punctures, and few setae; clypeus dark bluish-green with bright green tinge, anterior margin slightly concave, with scarce small, deep punctures at margins; frons slightly sinuate, dark bluishgreen with bright green tinge, surface with numerous 
deep, confluent punctures, larger than punctures of clypeus, and many strong callosities, some callosities with violet tinge; vertex dark bluish-green with violet tinge, punctures bright green, with few small, shallow, not confluent punctures; bases of mandibles dark green with blue tinge, with numerous small, deep, not confluent punctures and few callosities; maxillary palpi dark green basally, dark blue distally; antennae dark bluish-green with bright green tinge. Pronotum: 1.5 times wider than long; widest at base; lateral margins slightly concave at base, expanded at middle and rounded to anterior angles; narrowest apically; lateral margins discontinuously and slightly carinate on middle toward base; anterior margin scarcely bisinuate, with weak median lobe; posterior margin slightly bisinuate, with broad median lobe; posterior angles slightly acute; disc moderately convex, slightly flattened along midline toward base; surface with abundant small, deep, confluent punctures, and some impunctate areas medially; punctures more confluent and with weak callosities laterally. Scutellum: dark bluishgreen, small, rounded. Elytra: apices dark bluish-green with violet tinge, weakly obliquely emarginate; outer and sutural angles not dentiform; disc moderately convex, with slightly impressed punctate striae, with fine, confluent punctures medially, but laterally with large, deep punctures; first three striae clearly visible; surface with small, transverse impressions basally, and with many large, finely punctate interstrial impressions, these commonly confluent in transverse groupings and densely clothed with setae; laterally with large and more confluent punctures and weak callosities. Prosternum: disc moderately convex, with numerous small, deep, confluent punctures and weak callosities laterally; few small, deep, not confluent punctures medially; along anterior margin with small, very confluent punctures; prosternal process metallic green, slightly convex, sulci with fine, confluent punctures, and few setae, apex bluntly rounded. Mesosternum: metallic green; surface without punctures medially; but with few small, deep, not confluent punctures laterally. Mesepimeron and Mesepisternum: dark bluish-green; with small, shallow, sparse punctures, and with few setae. Metasternum: surface flattened, with scarce fine punctures and clothed with fine setae medially; laterally with numerous small, shallow, confluent punctures. Metacoxae: with numerous small, confluent punctures, and weak callosities at middle to external lateral margin; at middle to internal lateral margin with fine, sparse punctures, and few setae. Femora: surface dark green with blue tinge, punctures bright green, dark blue at base. Tibiae: surface dark green with blue tinge, punctures bright green. Tarsi: bluishgreen with some purple tinge. Abdomen: first ventrite slightly concave along midline, with few small, shallow, not confluent punctures, and few setae, this concavity bordered by weak, impunctate carina; ventrites 2-5 convex; apex of last visible ventrite rounded; abdominal surface densely and discontinuously punctate, with abundant small, shallow, confluent punctures.

Male. Male genitalia as in Fig. 51.
Variation. This species (one male and one female examined) varies in the coloration; dorsal surface dark bluish-green with violet tinge to dark green medially and dark blue with violet tinge laterally; ventral surface metallic green to bluish-green or dark green; frons dark bluish-green to dark green; antennae dark bluish-green to olive green and first segment dark green; maxillary palpi dark blue to dark green; pronotal posterior angles dark bluish-green to bluish-violet and callosities dark bluishgreen to dark green; elytral impressions bright green to bluish-violet, apices dark bluish-green with violet tinge to dark green; prosternum metallic green to dark green medially; tarsi bluish-green, with some purple tinge to dark green.

Differential diagnosis. Lampetis mexicana is similar to L. viridicolor $\mathrm{sp}$. n. Lampetis viridicolor $\mathrm{sp}$. $\mathrm{n}$. dorsal surface is dark green with bluish and violet tinge, impressions bright green, punctures bright green margined with blue; ventral surface bright green medially and bright green with brassy-green and reddish tinge laterally, punctures bright green; first antennal segment dark green, the rest dark green with bluish tinge; elytral disc with slightly impressed punctate striae, surface with few small, finely punctate interstrial impressions, these isolated from each other.

Type material studied. Female holotype: [Tasco] [Mexicana/ Théry/ Théry det.] [museum paris/ 1935/ Coll. A. THÉRY] (MNHN).

Distribution. This species has been collected only in two localities from Mexico: Guerrero: Acapulco, Taxco.

\section{Lampetis (Spinthoptera) monilis (Chevrolat, 1834)}

(Figs 22, 52)

Lampetis monilis Chevrolat, 1834: No. 3.

Psiloptera monilis; Gemminger \& Harold, 1869: 1367; Saunders, 1871: 25; Waterhouse, 1882: 8; Kerremans, 1892: 62; 1900: 288; 1903: 94; 1910: 146; Obenberger, 1926: 167; Blackwelder, 1944: 311; Westcott et al., 1990: 230.

Lampetis guatemalensis Thomson, 1879a: 12.

Psiloptera guatemalensis Waterhouse, 1889: 173; Kerremans, 1892: 62 (syn. of monilis); 1900: 288; 1903: 94; 1910: 146; Obenberger, 1926: 167 (var. of monilis); Blackwelder, 1944: 311.

Lampetis (Spinthoptera) monilis; Kurosawa, 1993: 580.

Diagnosis. Slender; ventral surface reddish-green medially, red-coppery laterally; punctures and impressions bright green with short, recumbent, white setae; first antennal segment red-coppery, the rest dark brown with brassy tinge; pronotum bright green; elytral surface bright green with reddish tinge at middle, reliefs reddish and greenish, with strongly impressed punctate striae, generally after four striae toward lateral margins with few small, punctate, bright green interstrial impressions; first ventrite slightly concave along midline, concavity narrow, ventrite 2 flattened along midline.

Male redescription. Length 13.9-24.8 mm; width 4.7-9.0 $\mathrm{mm}$. Head: Labrum bright green with brassy and redish tinge, with few small, shallow, not confluent punctures; clypeus bright green with some brassy and cupreous tinge, anterior margin slightly emarginate at 
middle, with few small, deep punctures at margins; frons bright green, callosities reddish-green, slightly sinuate, with abundant small, deep, confluent punctures, and few small callosities, punctures bluish-green with scarce setae; vertex surface reddish-green; bases of mandibles bright green, with few small, deep, confluent punctures; maxillary palpi reddish-green. Pronotum: 1.6 times wider than long; widest at middle; lateral margins subparallel at base, slightly expanded at middle, then slightly obliquely converging to anterior angles; narrowest apically; lateral margins slightly carinate at middle to base; anterior and posterior margins weakly bisinuate, each with weak median lobe; posterior angles slightly acute; disc moderately convex, flattened in midline toward base, surface with small, deep, sparse punctures, some in groups of three or four medially; laterally with more confluent punctures and few weak callosities. Scutellum: bright green with cupreous tinge, small, transversely oval. Elytra: apices obliquely emarginate, outer and sutural angles dentiform; disc moderately convex, with strongly impressed punctate striae; surface slightly transversely impressed at base, and generally after the four striae toward lateral margins with few small, punctate interstrial impressions; these with scarce setae. Prosternum: disc moderately convex, with numerous small, deep, confluent punctures laterally, few small, deep punctures medially, but with numerous confluent punctures along anterior margin; prosternal process slightly convex, sulci with small, deep punctures, apex bluntly rounded. Mesosternum: without punctures medially, but with small, shallow, sparse punctures laterally. Mesepisternum and mesepimeron: with few small, shallow, sparse punctures. Metasternum: flattened, with scarce fine punctures, with fine setae medially; small, shallow, sparse punctures laterally. Metacoxae: along posterior margin with small, confluent punctures; at middle with small, deep, sparse punctures with scarce setae; toward internal lateral margin with scarce fine punctures; toward external lateral margin with scarce small, shallow punctures. Femora: surface reddish-green; with few small, shallow punctures. Tibiae: reddish-green, with abundant small, shallow, confluent punctures. Tarsi: bright green with reddish tinge. Abdomen: first ventrite slightly concave along midline, concavity narrow, with few fine punctures and bordered by slight, impunctate carina; ventrite 2 flattened along midline; ventrites 3-5 convex; apex of last visible ventrite feebly rounded with emargination at middle; abdominal surface with few small, shallow punctures medially, abundant punctures laterally. Male genitalia as in Fig. 52.

Female. Length 28.5-17.2 mm; width $10.8-6.0 \mathrm{~mm}$. Differs from male as follows: more robust in body shape; apex of last visible abdominal ventrite rounded with weak emargination at middle.

Variation. This species (50 males and 70 females examined) varies in the coloration; dorsal surface bright green with reddish tinge to bright green with reddish and yellowish tinge or bluish green with yellowish tinge; ventral surface reddish-green medially, red-coppery laterally to bright green or cupreous; punctures bright green to blue; clypeus and frons bright green to bluish green or bright green with yellowish tinge; vertex reddish-green to bright or dark green with reddish and cupreous tinge; bases of mandibles bright green to bluish green; first antennal segment red-coppery to cupreous, the rest dark brown with brassy tinge to dark brown with bright green and cupreous tinge; pronotum bright green to bright green with reddish tinge; scutellum bright green with cupreous tinge to reddish tinge, or cupreous; elytra impressions bright green to bright green margined with blue; femora and tibiae bright green with yellowish and reddish tinge to bright green with bluish tinge, or cupreous; tarsi bright green with reddish tinge to bright green with bluish tinge, or dark green.

Differential diagnosis. Lampetis monilis is similar to L. granulifera and L. cyanitarsis sp. n. Lampetis granulifera is moderately robust; dorsal surface bright green laterally, bright green with reddish and yellowish tinge medially; ventral surface reddish-green medially, redcoppery with yellowish tinge laterally; punctures bright green; impressions yellowish; pronotal lateral margins slightly concave at base, slightly expanded at middle, then obliquely converging to anterior angles; elytral disc with strongly impressed punctate striae and after the second striae with many finely punctate interstrial impressions. Lampetis cyanitarsis sp. $\mathrm{n}$. dorsal surface is bright green with reddish tinge medially and laterally, punctures bright green margined with blue or violet; ventral surface redcoppery medially, bright green with reddish and brassy tinge laterally, punctures bright green; first antennal segment bright green with brassy tinge, the rest black with greenish tinge; pronotal lateral margins subparallel before base, slightly expanded at middle and obliquely converging to anterior angles; elytral surface with slightly impressed punctate striae, with few impressions along base and many small, finely punctate interstrial impressions; first ventrite slightly concave along midline; other ventrites convex.

Type material studied. Male lectotype designated here: [SYN-/ TYPE] [Mexique/ Sallé] [monilis/ Chevrolat/ TYPE] [Lectotype/ A.M. Corona des./ 2004] (BMNH). Males Paralectotypes: [SYN-/ TYPE] [monilis/ Chevr.] [Paralectotype/ A.M. Corona des./ 2004] (1, BMNH) (I consider that this specimen is Lampetis (Spinthoptera) granulifera [Laporte \& Gory, 1837]); [SYN-/ TYPE] [Guatém./ Chevrolat] [monilis/ Chevrolat] [Paralectotype/ A.M. Corona des./ 2004] (1, BMNH). Lampetis 8guatemalensis: Female holotype: [Gua.] [Type] [Guatemalensis/ Thoms. Type/ App. 1,12. Guatem] (MNHN).

Distribution. This species has been collected in Costa Rica, El Salvador, Guatemala, Honduras, Mexico, and Nicaragua. State and county records include the following: in El Salvador: Quezaltepeque. In Guatemala: Escuintla; Quetzaltenango: Hacienda El Reposo; Suchitepequez: Los Patos River, $14 \mathrm{mi}$ up; Jutiapa: Cañón de Monjoy. In Honduras: Comayagua: Siguatepeque; Santa Bárbara: 4 mi SW Quimistan; Zacapa, La Hacienda; El Zamorano, Tegucigalpa, Dormitorio Cabañas; El Zamorano, $30 \mathrm{~km}$ NE Tegucigalpa, El Ciruelo; El Paraiso vic. Yuscaran; Francisco Morazán: Cedros; La Paz. In Mexico: Chiapas: Ocosingo; $17 \mathrm{mi}$ W P.N. Montebello; $7 \mathrm{mi}$ SW Ocozocoautla; 20 km NW Ocozocoautla; Hwy. 195, 15 km S Jct 190; 
26 km E Cintalapa; Oaxaca: 10 mi SE Tapanatepec; Tabasco: Cárdenas; Veracruz: Jalapa. Nicaragua: Nueva Segovia, Dipilto. Phenology. Collected from May to December.

\section{Lampetis (Spinthoptera) obscura Thomson, 1879}

(Figs 26, 56, 74)

Lampetis obscura Thomson, 1879a: 11.

Psiloptera obscura; Kerremans, 1903: 93; 1910: 134 (syn. of thomsoni); Waterhouse, 1889: 172; Obenberger, 1926: 169; Blackwelder, 1944: 311.

Psiloptera thomsoni Kerremans, 1910: 134 (replacement name for obscura Thomson, 1879a); Obenberger, 1926: 169; Blackwelder, 1944: 311.

Lampetis (Spinthoptera) thomsoni; Kurosawa, 1993: 580.

Lampetis (Spinthoptera) obscura; Bellamy, 2004: 258 (new status).

Diagnosis. Dorsal surface bright black with brassy tinge, punctures brassy with large recumbent, whiteyellowish setae; ventral surface bright black with purple tinge, punctures brassy with abundant setae; first three antennal segments bright black with violet and blue tinge, the rest bright black with brassy green and violet tinge; pronotum constricted at posterior margin, surface with a weakly impressed median furrow extending from posterior margin to near anterior margin; elytral disc with slightly impressed punctate striae, four striae visible; first abdominal ventrite slightly concave along midline.

Male redescription. Length $15.1-21.7 \mathrm{~mm}$; width 4.9-7.6 mm. Head: Bright black with brassy tinge, punctures brassy with abundant large, semierect, whiteyellowish setae; callosities with brassy and violet tinge; labrum with abundant small, shallow, confluent punctures; clypeus with group of small shallow punctures, with impunctate areas; frons sinuate, with numerous large, punctures and weak callosities, along margin of eyes with numerous small, deep, brassy punctures with abundat setae; vertex with few large, deep punctures; bases of mandibles bright black with violet or blue tinge, with numerous small, deep, not confluent punctures. Pronotum: 1.5 times wider than long; widest at middle; lateral margins concave at base, expanded and rounded at middle and converging to anterior angles; narrowest anteriorly; lateral margins slightly carinate at middle; anterior and posterior margins bisinuate, each with weak median lobe; posterior angles slightly acute; disc convex, with a weakly impressed median furrow extending from posterior margin to near anterior margin, this impression finely punctate; surface with few large, shallow punctures medially; laterally with abundant larger, deep, more confluent punctures and few callosities. Scutellum: bright black with brassy green and violet tinge; slightly expanded transversally. Elytra: apices obliquely and slightly emarginate, outer and sutural angles slightly dentiform, outer angle more dentiform than sutural angle; disc convex, with slightly impressed punctate striae, four striae visible; surface transversely impressed basally, with numerous small, deep, confluent punctures with abundant setae; after the second striae with many small, finely punctate, brassy interstrial impressions, commonly confluent in transverse and oblique groupings, toward lateral margins with more confluent impressions and numerous callosities. Prosternum: disc moderately convex, densely punctate laterally, with large, deep and confluent punctures and few callosities; scarce punctures medially; prosternal process weakly convex, sulci with large, deep, confluent punctures, with abundant setae, apex bluntly rounded. Mesosternum: bright black, without punctures medially, but with abundant large, deep, confluent punctures laterally. Metasternum: bright black with purple tinge; surface flattened, finely punctate with fine setae medially; numerous large, deep, confluent punctures laterally. Metacoxae: along posterior margin at middle with numerous small, deep, confluent punctures; along anterior margin with numerous small, not confluent punctures; toward internal lateral margin with numerous small, confluent punctures; at middle with numerous large, not confluent punctures with callosities. Femora: surface bright black with purple and green tinge; with numerous large punctures, with abundant setae. Tibiae: surface black with violet tinge; with abundant setae. Tarsi: black with blue and violet tinge; with abundant large setae. Abdomen: first ventrite concave along midline, concavity narrow with scarce fine punctures, and abundant fine setae, and bordered by impunctate carinae forming a channel; ventrites $2-5$ convex; apex of last visible ventrite truncate with weak emargination at middle; abdominal surface with abundant large, confluent, irregular punctures. Male genitalia as in Fig. 56.

Female. Length 15.6-27.9 mm; width 5.3-10.0 mm.

Differential diagnosis. Lampetis obscura is similar to L. cupreopunctata. Lampetis cupreopunctata dorsal surface is black with impressions and punctures cupreous, ventral surface cupreous; pronotum with a weak midline impression extending from posterior margin almost to anterior margin; elytral disc with moderately impressed punctate striae.

Variation. This species (29 males and 31 females examined) varies in the coloration, dorsal and ventral surfaces bright black to bright greenish black; and scutellum shape, some specimens with rounded or oval scutellum.

Type material studied. Female holotype: [Th./ Type] [Obscura/ (FF. Deyr. M.SS)./ Thoms. Type/ Ap. I. II. Mex.] [Ex Musaeo/ JAMES THOMSON] (MNHN).

Distribution. This species has been collected only in Mexico, state and county records include the following: Oaxaca: $7 \mathrm{~km}$ NNW, Díaz Ordaz, $17^{\circ} 00 \mathrm{~N}, 96^{\circ} 26 \mathrm{~W}$; N of Hwy. $190,7 \mathrm{~km} \mathrm{~N}$ Diaz Ordaz; Hwy. 175, 10 km NE Oaxaca; km 40 OaxacaGuelatao, vic. Oaxaca; 8 km NE Oaxaca, Hwy. 175; Ruins of Monte Alban; 4 km NE Teotitlán del Valle; 9 km NE Teotitlán del Valle; Puebla: vic. Coxcatlán; Veracruz: Tecolutla.

Adult host plants. On Mimosa sp., and Quercus sp. (Fagaceae).

Phenology. Collected from June to September.

Lampetis (Spinthoptera) simplex (Waterhouse, 1882)

(Figs 23, 53, 72)

Psiloptera simplex Waterhouse, 1882: 9; Kerremans, 1885: 134; 1892: 66; 1903: 102; 1910: 143; Dugés, 1891: 4.

Psiloptera (Lampetis) simplex; Obenberger, 1926: 168; Blackwelder, 1944: 311. 
Lampetis (Spinthoptera) simplex; Kurosawa, 1993: 580.

Diagnosis. Dorsal surface black; ventral surface bright red medially, black with reddish tinge laterally; punctures cupreous margined with red, with short, recumbent, white setae; first antennal segment red, the rest black with reddish tinge; pronotal surface with numerous small, deep, not confluent punctures medially; elytral surface with strongly impressed punctate striae, after fifth interval with few small punctures; first ventrite feebly concave along midline, other ventrites convex.

Male redescription. Length 16.1-24.1 mm; width 5.4-8.1 mm. Head: Labrum bright red, with small, shallow, not confluent punctures; clypeus bright red with cupreous tinge, anterior margin concave, with numerous small punctures at margins, larger toward frons, without punctures at middle; frons flattened, black, callosities with reddish tinge, with small, deep, confluent punctures and few weak callosities; vertex black with reddish tinge; bases of mandibles red, rugosely punctate, with small, deep, confluent punctures. Pronotum: 1.7 times wider than long, widest at middle; lateral margins subparallel at base, weakly expanded at middle, then slightly and obliquely converging to anterior angles; narrowest anteriorly; lateral margins carinate on middle to posterior margin; anterior and posterior margins slightly bisinuate with weak, broad median lobe; disc moderately convex, flattened in midline toward base; surface with numerous small, deep, not confluent punctures medially; laterally with more confluent punctures and few weak callosities. Scutellum: black with reddish tinge; small, punctiform. Elytra: apices weakly, obliquely emarginate, outer and sutural angles not dentiform; disc moderately convex, with strongly impressed punctate striae; surface with scarce impressions along base, and after fifth interval with few small punctures, deeper and more numerous laterally, with few weak callosities toward lateral margins, some punctures with fine setae. Prosternum: disc moderately convex; surface with scarce small, deep, confluent punctures medially, more abundant and confluent laterally; prosternal process flattened, sulci with small, deep, confluent punctures, with abundant setae; apex bluntly rounded. Mesosternum: surface with few small, shallow punctures laterally, without punctures medially; punctures with few setae. Mesepisternum and mesepimeron: with few small, not confluent punctures. Metasternum: flattened; with scarce fine punctures medially; numerous small, deep, not confluent punctures laterally. Metacoxae: surface with abundant small, deep, confluent punctures medially; toward external lateral margin with few small, sparse punctures; toward internal lateral margin with scarce fine punctures; along posterior margin with fine, confluent punctures. Femora: black, with reddish tinge; with numerous small, deep, not confluent punctures. Tibiae: black; densely punctate, with small, shallow, confluent punctures. Tarsi: black with bronze tinge. Abdomen: first ventrite feebly concave along midline, this concavity narrow with few fine punctures and bordered by weak, impunctate carina; other ventrites convex; apex of last visible ventrite feebly rounded with weak emargination at middle; abdominal surface densely and irregularly punctate. Male genitalia as in Fig. 53.

Female. Length 17.9-25.4 mm; width $6.3-8.9 \mathrm{~mm}$. Differs from male as follows: more robust in body shape.

Variation. This species (16 males and 16 females examined) varies in coloration; dorsal surface black to black with red and bronze or blue tinge; punctures cupreous margined with red to red.

Differential diagnosis. Lampetis simplex is similar to L. christophi and L. hondurensis sp. n. Lampetis christophi dorsal and ventral surfaces are dark brown with olive-green and purple tinge; dorsal surface with punctures olive green margined with purple; ventral surface with punctures purple; pronotal lateral margins slightly concave at base, slightly expanded at middle, then obliquely converging to anterior angles; elytra with purple tinge laterally, apices purple, disc with slightly impressed punctate striae, first three striae clearly visible. Lampetis hondurensis sp. $\mathrm{n}$. is moderately robust; surface dark brown with bronze and purplish tinge, punctures brassy margined with purple; antennae black with bronze tinge; pronotal lateral margins subparallel at base, slightly expanded and rounded before middle and then slightly obliquely converging to anterior angles; elytral surface with moderately impressed punctate striae, and few punctate interstrial impressions; first ventrite slightly concave along midline, ventrite 2 flattened.

Type material studied. Female lectotype: [Chontales,/ Nicaragua,/ T. Belt.] [Psiloptera/ simplex,/ (Type) Waterh.] [LECTOTYPE Psiloptera simplex Waterh. ? Det. G.H. Nelson 1980] (BMNH). Female paralectotype: [Chontales,/ Nicaragua,/ T. Belt.] [Paralectotype] (BMNH).

Distribution. This species has been collected in Costa Rica, El Salvador, Honduras, Mexico, and Nicaragua. State and county records include the following: in Costa Rica: Port Parker; Guanacaste: Cañas; 20 km SW Cañas; 14 km S Cañas; La Pacífica, 7 km N Cañas; 4 km NW Cañas; 4 km W Cañas; 10 km N Brasilito; 8 km NW Bagaces; 15 km SW Bagaces; 24 mi NW Liberia; 3 km NO Nacaome, 100 m, P.N. Barra Honda; Sta. Cruz, Lagunilla; $5 \mathrm{~km} N$ Tlaran Ridge, above lag. Arenal. In El Salvador: La Unión: Cutuco. In Honduras: Choluteca: 19.5 km E Choluteca; Francisco Morazán: Tegucigalpa; Comayagua. In Mexico: Chiapas: 9 mi NW El Ocotal; Veracruz: Actopan. In Nicaragua: León; Managua: Lake Xiloá.

Adult host plants. On Cordia inermis (Boraginaceae), and Byrsonima sp. (Malpighiaceae).

Phenology. Collected from January to December.

\section{Lampetis (Spinthoptera) srdinkoana (Obenberger, 1924)}

(Figs 24, 54)

Psiloptera (Lampetis) srdinkoana Obenberger, 1924a: 101; 1926: 169; Blackwelder, 1944: 311.

Lampetis (Spinthoptera) srdinkoana; Kurosawa, 1993: 580.

Diagnosis. Robust; dorsal and ventral surfaces reddish brown with golden green tinge; punctures bright green margined with golden green; head reddish brown with golden green tinge; antennae dark brown with golden green tinge; pronotum slightly flattened in midline toward base, along lateral margins with a small depression; along elytral lateral margins with a depression formed by abun- 
dant fine, confluent punctures; first and second ventrites slightly concave along midline.

Male redescription. Length $21.9-24.8 \mathrm{~mm}$; width 7.9-9.2 mm. Head: Labrum with few shallow, punctures, with few setae; clypeus with few small, deep punctures, punctures larger and deeper near frons; frons sinuate, with numerous small, deep, confluent punctures, and numerous weak callosities, with few setae; along border of the eyes with abundant small, confluent punctures, with abundant setae; vertex with few large, deep, not confluent punctures, with scarce setae; bases of mandibles with numerous small, deep, confluent punctures. Pronotum: 1.5 times wider than long; widest at middle; lateral margins subparallel near base, slightly expanded at middle, then obliquely converging to anterior angles, narrowest anteriorly; lateral margins discontinuously carinate at middle toward base; anterior and posterior margins slightly bisinuate, anterior margin with weak median lobe, posterior margin with weak, broad lobe; posterior angles slightly acute; disc slightly convex, flattened in midline toward base; surface with numerous small, deep, confluent punctures medially and laterally, along lateral margins with a depression formed by abundant small, confluent punctures. Scutellum: reddish brown with golden green tinge; small, oval. Elytra: apices obliquely emarginate; outer angle more dentiform than sutural angle; disc moderately convex, with strongly impressed punctate striae formed by small, deep punctures toward apices, and larger, deeper punctures at anterior margin; eight striae visible; surface with scarce impressions along base, and intervals with scarce small punctures, these clothed with fine setae; along lateral margins with a depression formed by abundant small, deep, confluent punctures, with fine setae, this depression with bright or golden green and reddish tinge. Prosternum: disc convex, with numerous small, deep, confluent punctures laterally; few less confluent medially; prosternal process flattened, sulci with small, deep, confluent punctures, apex bluntly rounded. Mesosternum: without punctures medially, but with few small, deep punctures laterally. Mesepisternum and mesepimeron: with few small, deep, not confluent punctures. Metasternum: flattened medially, finely punctate and clothed with fine setae medially; laterally with numerous small, deep, not confluent punctures. Metacoxae: along posterior margin with small, shallow punctures; few small, deep, confluent punctures medially; with scarce punctures laterally. Femora: reddish brown with golden green tinge, with few small, shallow, not confluent punctures. Tibiae: reddish brown with golden green tinge; with numerous small, shallow punctures. Tarsi: black with bluish green tinge, punctures red. Abdomen: first ventrite slightly concave along midline, concavity narrow and finely punctate, with fine setae and bordered weakly by impunctate carina; ventrite 2 slightly flattened along midline; ventrites 3-5 convex; apex of last visible ventrite feebly rounded with weak emargination at middle; abdominal surface with abundant small, shallow, confluent punctures. Male genitalia as in figure 54 .

Female. Length 21.8-27.6 mm; width 7.8-10.8 mm.
Variation. This species ( 2 males and 3 females examined) varies in the coloration; ventral surface reddish brown with golden green tinge to reddish brown with reddish and bluish tinge; setae from white to yellowish-white.

Differential diagnosis. Lampetis srdinkoana looks like to L. hirtomaculata. Lampetis hirtomaculata is metallic red with dark bronze tinge below; punctures and impressions bright green; metasternum and metacoxae with reddish tinge laterally; pronotum dark bronze with metallic reddish tinge, surface along anterior margin to midline with a slight line of abundant small, confluent punctures; elytra dark bronze with purplish and brassy-green tinge, with four transversal impressions from lateral margins to middle, the last one smaller than the rest.

Type material studied. Male lectotype designated here: [Costa Rica/ Turrialba] [Typus] [Psiloptera srdinkoana/ Type/ Det. Dr. Obenberger] [Mus. Nat. Pragae/ Inv. 20683] [Lectotype/ A.M. Corona des./ 2004] (NMPC). Male Paralectotype: [Coll. I.R.Sc.N.B./ Costa Rica/ Koll. Dr A.Frh.v.Hoschek/ Turrialba,/ C.Rica] [Syntype] [Paralectotype/ A.M. Corona des./ 2004] (ISNB).

Distribution. This species is known only in Costa Rica: Cártago: Turrialba; Guanacaste: 3 km SE Río Naranjo; Estación Las Pailas, P.N. Rincón de la Vieja.

Phenology. Collected from June to November.

\section{Lampetis (Spinthoptera) straba (Chevrolat, 1867)}

(Figs 25, 55, 65)

Psiloptera straba Chevrolat, 1867: 575; Gemminger \& Harold, 1869: 1369; Saunders, 1871: 24; Gundlach, 1891: 158; Kerremans, 1892: 66; 1903: 102; 1910: 58.

Psiloptera (Lampetis) straba; Fisher, 1925: 58; Obenberger, 1926: 169; Blackwelder, 1944: 311.

Lampetis (Spinthoptera) straba; Kurosawa, 1993: 580.

Diagnosis. Ventral surface red-coppery at middle, dark brown with red-coppery tinge laterally; punctures redcoppery margined with brassy-green or brassy, with short, semierect, white setae; impressions red-coppery with cupreous tinge; first antennal segment red-coppery, the rest dark brown with cupreous and red-coppery tinge; pronotum dark brown with cupreous tinge, surface sinuate at sides of midline near basal margin; elytra dark brown with cupreous tinge, reliefs reddish, surface with strongly impressed punctate striae, and with many interstrial impressions; first ventrite weakly concave along midline, ventrite 2 flattened along midline.

Female Holotype redescription. Total body length $31.2 \mathrm{~mm}$; width $10.6 \mathrm{~mm}$. Head: Labrum red coppery, with cupreous tinge, with numerous small, shallow, confluent punctures, with few setae; clypeus red-coppery, anterior margin concave without punctures, toward posterior margin with numerous small, deep, not confluent punctures; frons sinuate, dark brown, callosities cupreous and red-coppery, punctures cupreous margined with brassy or golden-green, coarsely and rugosely punctate with numerous large, deep, confluent punctures and some large, strong callosities; vertex dark brown with cupreous and reddish-coppery tinge, punctures cupreous margined with brassy or golden-green; bases of mandibles dark 
brown with cupreous tinge, punctures cupreous margined with brassy-green, rugosely punctate with small, deep, confluent puntures; maxillary palpi red-coppery with purple tinge. Pronotum: 1.6 times wider than long, widest at middle; lateral margins slightly concave before base, expanded at middle and obliquely converging to anterior angles, narrowest anteriorly; lateral margins carinate; anterior and posterior margins slightly bisinuate with slight broad median lobe; posterior angles slightly acute; disc moderately convex, slightly flattened in midline toward base, surface sinuate at sides of midline near posterior margin; along lateral margins, and anterior and posterior margins with a weak depression, but on anterior margin this depression is interrupted at middle; at sides of midline with two weak longitudinal impressions from anterior to posterior margins, these impressions formed by numerous small, shallow, confluent punctures, and usually clothed with white pulverulence; the rest of surface without punctures. Scutellum: dark brown with red coppery tinge; transversely oval. Elytra: apices obliquely emarginate, outer and sutural angles dentiform; disc moderately convex with slightly impressed punctate striae, formed by fine, shallow punctures; surface with few small impressions along anterior margin and many large, finely punctate interstrial impressions, usually isolated from each other, and clothed with short setae, and covered with white pulverulence; laterally with deep, confluent punctures, and weak callosities. Prosternum: disc slightly convex; surface with abundant small, deep, confluent punctures laterally, with scarce punctures medially, punctures with few setae; prosternal process slightly convex, sulci with fine, confluent punctures, with few setae; apex bluntly rounded. Mesosternum: surface with numerous small, shallow, confluent punctures laterally, without punctures medially. Mesepisternum: with few small, shallow, not confluent punctures. Mesepimeron: without punctures. Metasternum: flattened, with scarce fine punctures medially, with fine setae; abundant, small, deep, very confluent punctures laterally. Metacoxae: surface with abundant small, deep, confluent punctures at middle to external lateral margin; scarce, fine punctures toward internal lateral margin. Femora: red-coppery with brassy tinge at light; with numerous small, deep, punctures, confluent in groups. Tibiae: red-coppery, punctures cupreous; surface with few fine, not confluent punctures. Tarsi: dark brown with cupreous, reddish and bluish tinge. Abdomen: with first ventrite weakly concave along midline, this concavity with scarce fine punctures and not bordered by carina; ventrite 2 slightly flattened along midline; ventrites 3-5 convex; apex of last visible ventrite rounded; abdominal surface sparsely and irregularly punctate medially, coarsely and irregularly punctate laterally.

Male. Length 20.9-25.4 mm; width 6.9-8.8 mm. Differs from male as follows: apex of last visible abdominal ventrite weakly rounded with slight emargination at middle. Male genitalia as in Fig. 55.

Variation. Female: length 21.9-29.2 mm; width 8.1-9.9 mm. This species (six males and four females examined) varies in the coloration; dorsal surface dark brown to dark brown with strong reddish tinge; elytra with bluish tinge at apices; labrum red-coppery with cupreous tinge to brassy-green; ventral surface redcoppery at middle, dark brown with red-coppery tinge laterally to cupreous with purple and bluish tinge; femora red-coppery to cupreous; tibiae red-coppery to cupreous with strong purple tinge.

Differential diagnosis. Lampetis straba is similar to $L$. bahamica. Lampetis bahamica ventral surface is dark brown with cupreous and blue tinge, punctures olivegreen; head dark brown with cupreous tinge; pronotum and elytra with shining, bluish, purplish, cupreous tinge; pronotum with two slight transverse arcuate impressions; elytra with many large interstrial impressions.

Type material studied. Female holotype: [Holo-/ type] [straba/ Chevr.] (BMNH).

Distribution. This species has been found only from Cuba: Isla de la Juventud: Santa Fé; Columbia; Sabanilla: N Sabanilla, Oriente Prov.; Holguín: Woodfred; Sierra de Mayari; 14 km N Viñales.

Adult host plant. On Ficus elastica (Moraceae) (Fisher 1925).

Phenology. Collected from March to September.

\section{Lampetis (Spinthoptera) tigrina sp. $\mathbf{n}$.}

(Figs 27, 57, 71)

Diagnosis. Slender; ventral surface purple with greenish tinge; punctures dark green margined with bright green; punctures with short, semierect, white setae; labrum and clypeus purple with greenish tinge, punctures bright green; first five antennal segments purple, the rest black with purplish and greenish tinge; pronotum purple with greenish tinge, with strong and broad depression at middle of base; elytra bright green with reliefs purple medially, bright green with reliefs purple and bluishgreen laterally, apices purple, disc convex with slightly impressed punctate striae, these striae with fine punctures, three striae difficultly visible; first ventrite slightly concave along midline, ventrite 2 slightly flattened.

Male description. Head: Labrum granulose, with few small, shallow punctures; clypeus anterior margin slightly concave, without punctures medially, with few small, deep punctures near frons; frons purple, punctures bright green, slightly sinuate, coarsely and rugosely punctate with abundant small, deep, confluent punctures and numerous weak callosities, punctures with abundant setae; vertex purple, with few small, shallow punctures; bases of mandibles purple with bluish tinge, with few small, deep, not confluent punctures, more confluent near apices; maxillary palpi purple with greenish tinge at bases. Pronotum: 1.7 times wider than long, widest at middle; lateral margins moderately concave at base, expanded and rounded before middle and obliquely converging to anterior angles; narrowest anteriorly; lateral margins carinate; along anterior margin to middle with a slight line of fine, deep, confluent punctures; anterior margin weakly bisinuate with weak median lobe; posterior margin slightly bisinuate with slight, broad median lobe; posterior angles slightly acute; disc convex, flattened in midline toward base and with strong, broad 
depression at midline near base; surface with few small, confluent punctures, with impunctate areas medially; laterally with numerous small, deep, confluent punctures and few callosities. Scutellum: purple with greenish tinge, small, puntiform. Elytra: apices slightly, obliquely emarginate, outer and sutural angles slightly dentiform; disc convex with slightly impressed punctate striae, these striae with fine punctures, three striae difficultly visible; surface with few impressions along anterior margin and many small, finely punctate, interstrial impressions, and the intervals with numerous small, shallow punctures; these commonly confluent in transverse and oblique groupings, with abundant callosities laterally. Prosternum: disc moderately convex; surface with abundant small, deep, confluent punctures laterally, and weak callosities; without punctures medially, punctures with abundant setae; prosternal process slightly convex, sulci with small, shallow, confluent punctures with numerous setae; apex bluntly rounded. Mesosternum: surface with numerous small, shallow, confluent punctures laterally, without punctures medially; with abundant setae. Mesepisternum and mesepimeron: purple with greenish and yellowish tinge; with few small, shallow, not confluent punctures. Metasternum: flattened and with numerous fine punctures medially, with numerous fine setae; abundant, small, deep, confluent punctures laterally. Metacoxae: with few small, shallow, not confluent punctures toward external and internal lateral margins; abundant confluent punctures at middle. Femora: purple with greenish tinge; with numerous small, deep, confluent punctures. Tibiae: purple with greenish tinge; densely punctate. Tarsi: purple with greenish tinge. Abdomen: first ventrite slightly concave along midline, this concavity narrow and bordered with slight, impunctate carina, and with numerous small, shallow punctures; ventrite 2 slightly flattened; other ventrites convex; apex of last visible ventrite feebly rounded with weak emargination at middle; abdominal surface with abundant small, shallow, confluent, irregular punctures with abundant setae. Length $16.8-20.3 \mathrm{~mm}$; width $5.5-6.8 \mathrm{~mm}$. Male genitalia as in Fig. 57.

Female. Unknown.

Variation. This species varies in the coloration: dorsal and ventral surfaces purple with green tinge to purple with greenish, yellowish and bluish tinge; punctures from dark green margined with bright green to golden green; tarsi from purple with greenish tinge to purple with greenish and bluish tinge.

Differential diagnosis. Lampetis tigrina sp. $\mathrm{n}$. is similar to L. monilis and L. chamela sp. n. Lampetis monilis ventral surface is reddish-green medially, redcoppery laterally; punctures and impressions bright green; pronotum bright green, lateral margins subparallel at base, slightly expanded and rounded at middle, then obliquely converging to anterior angles; elytral surface bright green with reddish tinge at middle, reliefs reddish and greenish, with strongly impressed punctate striae, generally after the four striae toward lateral margins with few finely punctate, interstrial impressions; and second ventrite flattened along midline. Lampetis chamela sp. $\mathrm{n}$. dorsal surface is red-coppery medially, bright green laterally; ventral surface bright red-coppery; first antennal segment bright green, the rest dark brown with bright green and violet or blue tinge; pronotal lateral margins slightly concave at base, expanded at middle, then obliquely converging to anterior angles; elytra color redcoppery as far as the fourth striae, bright green toward lateral margins, apices bright green with blue tinge, disc with feebly impressed punctate striae and with finely punctate interstrial impressions, usually isolated from each other.

Type material. Male holotype: [MEXICO: Oaxaca/ 3 mi. se. Matatlan/ (Microondas road)/ elev. 6650 ft.] [July 17, 1987/ Kovarik, Schaffner] (GHNC). Males paratypes: [MEXICO, Oaxaca/ 7-8 mi. E Mnla./ 6200' Jul 3-9, '94/ E. Giesbert, coll.] (1, EMEC); [Mex: Oaxaca,/ Totolapan, 18 mi./ NW. VIII-29-63] [J. Doyen/ Collector] (1, EMEC); [MEX., Oaxaca/ km. 79, Carretera/ Pto. Angel/ 10-IX-1979/ E. Mariño] (1, RLWE).

Etymology. The name of this species is derived from the Latin substantive tigris (tiger) referring to the disposition of the coloration similar to a tiger.

Distribution. Kwon only from Mexico: Oaxaca, $3 \mathrm{mi}$ SE Matatlan; 7-8 mi E Matatlan; 18 mi NW Totolapan; km 79, Carretera Pto. Angel.

\section{Lampetis (Spinthoptera) torquata (Dalman, 1823)}

(Figs 28, 58, 66)

Buprestis torquata Dalman, 1823: 54; Laporte \& Gory, 1836: 36; Jacquelin du Val, 1857: 59.

Psiloptera torquata; Chevrolat, 1867: 576; Gemminger \& Harold, 1869: 1369; Saunders, 1871: 23; Gundlach, 1891: 159; Kerremans, 1892: 66; 1903: 93; 1910: 55

Psiloptera (Lampetis) torquata; Fisher, 1925: 51; Obenberger, 1926: 169; 1934: 54; Blackwelder, 1944: 311.

Psiloptera (Lampetis) torquata var. jamaicensis Fisher, 1925: 53; Théry, 1927: 254; Obenberger, 1926: 169; Blackwelder, 1944: 311

Lampetis (Spinthoptera) torquata; Kurosawa, 1993: 580.

Diagnosis. Dorsal surface dark green, punctures and impressions golden-green margined with purple; ventral surface olive-green medially, becoming purple laterally, punctures golden-green; punctures with short, recumbent, white setae; first antennal segment golden-green, the rest segments dark brown with golden-green tinge; pronotal surface with two transverse arcuate impressions; along elytral lateral margin with a longitudinal depression; first ventrite slightly concave along midline.

Male redescription. Length $15.7-21.5 \mathrm{~mm}$; width 5.9-8.6 mm. Head: Punctures golden-green; labrum golden-green, with numerous small, shallow, confluent punctures; clypeus dark green, with numerous larger than those of the labrum, deep, confluent punctures; frons dark green, flattened with numerous large, deep, confluent punctures and numerous callosities, along margin of eyes with abundant setae; vertex dark green, with few not confluent punctures; bases of mandibles golden-green with dark green tinge, punctures dark green, with numerous small, deep, confluent punctures and weak callosities; maxillary palpi golden-green with reddish tinge. Prono- 
tum: 1.6 times wider than long; widest at middle and base; lateral margins slightly concave at base, expanded at middle and rounded to anterior angles, slightly narrowed apically; lateral margins discontinuously carinate at middle toward base; anterior margin bisinuate, with weak median lobe; basal margin bisinuate with large rounded median lobe; posterior angles slightly acute; disc convex, slightly flattened along midline toward base; surface with two transverse arcuate impressions, densely covered with a golden-yellow pulverulence, one along anterior margin rather broadly interrupted at the middle, the other near posterior margin; these impressions with numerous fine, confluent punctures, with abundant setae; the rest of surface with extensive impunctate areas, these areas with granulose texture, becoming more granulose toward lateral margins. Scutellum: bronzy-green, transversely oval, slightly granulose. Elytra: apices weakly and obliquely emarginate; outer angle dentiform, sutural angle not dentiform; disc moderately convex, with slightly impressed punctate striae; surface with few transverse impressions basally, and many groups of few small, deep punctures between striae, punctures coarsey and irregularly placed, with fine setae; along lateral margin with a longitudinal depression covered with golden-yellow pulverulence similar to that on the pronotum. Prosternum: disc moderately convex, with numerous small, deep, confluent punctures, and slightly callosities laterally; without punctures at midline; prosternal process convex, sulci with abundant setae, apex bluntly rounded. Mesosternum: olive-green with dark green tinge, surface without punctures medially, but with abundant small, deep, confluent punctures laterally. Mesepimeron and mesepisternum: with abundant small, shallow, not confluent punctures, with abundant setae. Metasternum: surface flattened, with few fine, not confluent punctures and clothed with fine setae medially; laterally with numerous small, shallow, not confluent punctures, with some impunctate areas. Metacoxae: with numerous large, deep, confluent punctures, and weak callosities medially; abundant, small, shallow punctures, with abundant setae toward external lateral margin to middle; toward internal lateral margin with scarce small, shallow punctures. Femora: surface dark green, punctures golden-green with few small, shallow, not confluent punctures. Tibiae: surface dark green, punctures golden-green; with numerous small, shallow, not confluent punctures. Tarsi: dark green with some cupreous and golden-green areas. Abdomen: first ventrite slightly concave along midline, with few fine punctures, this concavity bordered by impunctate carinae; ventrites 2-5 convex; apex of last visible ventrite feebly rounded with weak emargination at middle; abdominal surface densely punctate, with abundant small, shallow, not confluent punctures. Male genitalia as in Fig. 58.

Female. Length 17.9-30.9 mm; width $6.9-12.1 \mathrm{~mm}$. Differs from male as follows: more robust in body shape.

Variation. This species (50 males and 59 females examined) varies in the coloration; head from dark to olive green; pronotum dark green to dark green with bronzy green tinge; scutellum from dark to bronzy green; ventrites olive green to dark green on the median parts. The specimens from Jamaica are similar in shape with those from other localities, but they differ from the rest in color: head reddish black, punctures red-coppery margined with olive tinge; first antennal segment red-coppery, the rest black; maxillary palpi red-coppery; pronotum, elytra and femur reddish black, punctures and impressions olive-green; scutellum red-coppery; ventral surface olive-green; tibiae red-coppery, punctures olivaceous.

Differential diagnosis. Similar to Lampetis aurifera. $L$. aurifera dorsal surface is strong purple with dark-green and golden-green tinge; head golden green; pronotal impressions as follows: a longitudinal median one, broader posteriorly and feebly interrupted in front of middle; a rather broad one on each side along anterior margin; a narrow one along lateral margins but not reaching to the posterior angles; and a transversely oblique one behind the middle; elytra without marginal impressions.

Type material. Not studied here.

Distribution. This species has been collected in Cuba, Haiti, and Jamaica. State and county records include the following: in Cuba: Sabana, La Mar, Oriente; Ciego de Ávila: Baraguá; Cienfuegos: Cayamas; La Milpa; N Cien Fuegos; Granma: Río Cauto; Guantánamo; Habana: Habana; Güines; Marianao H.; Holguín: Holguín; Isla de la Juventud: Punta del Gate; Las Tunas: Central Jaromú; Pasa Cavado; Pinar del Rio: Punta San Juan; Santa Clara; Santiago de Cuba: Aguadores, on the coast near Santiago de Cuba; Ciudamar, nr. Santiago. In Haiti: NordOuest: Cayenne (1M, MNHN).

Adult host plants. On Acacia farnesiana (Fabaceae), and Saccharum officinalis (Gramineae).

Phenology. Collected from February to December.

\section{Lampetis (Spinthoptera) viridicolor sp. $\mathrm{n}$.}

(Figs 29, 59)

Diagnosis. Dorsal surface dark green with bluish and violet tinge, impressions bright green, punctures bright green margined with blue; ventral surface bright green medially and bright green with brassy-green and reddish tinge laterally, punctures bright green; punctures with short, recumbent, white setae; first antennal segment dark green, the rest dark green with bluish tinge; pronotum dark green with bluish tinge; elytral surface with slightly impressed punctate striae, with few small, finely punctate, interstrial impressions, these isolated from each other; first ventrite slightly concave along midline, other ventrites convex.

Male description. Length 17.6-21.5 mm; width 6.0-7.6 mm. Head: Labrum dark green with brassy-green tinge, with few small, shallow punctures; clypeus dark green with brassy-green tinge, punctures bright green, anterior margin concave, with scarce punctures medially, with few small, deep punctures toward margins; frons dark green, callosities with brassy-green tinge, punctures dark green, slightly sinuate, coarsely and rugosely punctate with abundant small, deep, confluent punctures and numerous strong callosities; vertex dark green with brassy-green tinge; bases of mandibles dark green, with 
numerous small, deep, confluent punctures; maxillary palpi dark green. Pronotum: 1.6 times wider than long, widest at middle; lateral margins subparallel at base, slightly expanded and rounded at middle and then slightly obliquely converging to anterior angles; narrowest anteriorly; lateral margins slightly carinate at middle to posterior margin; along anterior margin to midline with a faint line of fine, confluent punctures; anterior and posterior margins weakly bisinuate with weak median lobe; posterior angles slightly acute; disc convex, flattened in midline toward base; surface with few small, deep, sparse punctures near base, confluent near anterior margin medially; larger, abundant, confluent punctures laterally, with few strong callosities. Scutellum: black with greenish and reddish tinge, small, puntiform. Elytra: apices obliquely emarginate, outer and sutural angles dentiform; disc moderately convex, with slightly impressed punctate striae, the striae with small, shallow, confluent punctures; surface with few impressions along base and few small, finely punctate, interstrial impressions, isolated from each other, laterally these impressions are more numerous confluent, larger, and with strong callosities; impressions with few setae. Prosternum: disc moderately convex; surface with abundant small, deep, confluent punctures, and weak callosities laterally; with few punctures medially; prosternal process flattened, sulci with small, deep, confluent punctures; apex bluntly rounded. Mesosternum: surface with numerous small, deep, confluent punctures laterally, without punctures medially. Mesepisternum and mesepimeron: with numerous small, shallow, not confluent punctures. Metasternum: flattened, with few fine punctures medially, with fine setae; abundant, small, deep, confluent punctures laterally. Metacoxae: with scarce small, shallow, sparse punctures at internal lateral margin; numerous and confluent at middle; toward external lateral margin with few small, deep punctures; along posterior margin to middle with numerous small, deep, confluent punctures. Femora: bright green, dark green at bases; with few small, deep punctures medially, numerous punctures laterally. Tibiae: bright green; densely punctate, with abundant small, shallow, confluent punctures. Tarsi: dark green with bluish and purplish tinge. Abdomen: first ventrite slightly concave along midline, this concavity is narrow and bordered with impunctate carina, and with numerous fine punctures; other ventrites convex; apex of last visible ventrite feebly rounded with emargination at middle; abdominal surface with abundant small, shallow, confluent, irregular punctures with abundant setae. Male genitalia as in Fig. 59.

Female. Length 15.7-28.3 mm; width 5.7-10.6 mm. Differs from male as follows: more robust in body shape.

Variation. This species varies in the coloration: ventral surface bright green medially to reddish-green.

Differential diagnosis. Lampetis viridicolor $\mathrm{sp} . \mathrm{n}$. is similar to L. mexicana and L. monilis. Lampetis mexicana ventral surface has punctures metallic green; pronotum dark bluish-green, lateral margins slightly concave before base, expanded at middle and rounded to anterior angles; elytra dark bluish-green with violet tinge; disc with slightly impressed punctate striae, first three striae clearly visible, surface with many large, finely punctate, interstrial impressions. Lampetis monilis is slender, dorsal surface reddish-green medially, red-coppery laterally; punctures and impressions bright green; pronotum bright green, lateral margins subparallel at base, slightly expanded and rounded at middle, then obliquely converging to anterior angles; elytral surface bright green with reddish tinge at middle, reliefs reddish and greenish, with strongly impressed punctate striae, generally after the four striae toward lateral margins with few finely punctate, interstrial impressions; first ventrite slightly concave along midline, ventrite 2 flattened along midline.

Type material. Male holotype: [MEXICO: Chiapas, $\mathrm{Mu}-/$ nicipio La Trinita-/ ria, Lagunas de Mon-/ tebello, alt. 1371 m/ 2-XI-1976/ D.E. \& J.A. Breedlove/ Cal. Acad.Sci. Coll.] (CASC). 11(3M， 8F) Paratypes: [MEXICO: Chiapas, Mu-/nicipio La Trinita-/ ria, Lagunas de Mon-/ tebello, alt. 1371 m/ 2-XI-1976/ D.E. \& J.A. Breedlove/ Cal. Acad.Sci. Coll.] (2M, 6F, CASC); [MEXICO, CHIAPAS/ "EL AGUACERO"/ $16 \mathrm{~km}$ W OCOZOCOAUTLA/ OCT 16-23, 1988/ E. GIESBERT, COLL.] (1M, 1F, EMEC); [HONDURAS: Morazan/ Dept., San Francisco/ 2.7 km S Olancho line/ 3-III-1990, S.W. Dunkle] (1F, FSCA).

Etymology. The name of this species is derived from the Latin adjective viridis (green) and substantive color (colour) referring to the green coloration of the body of this species.

Distribution. This species has been collected only in Honduras and Mexico. State and county records include the following: in Honduras: Francisco Morazán: San Francisco, $2.7 \mathrm{~km} \mathrm{~S}$ Olanchito. In Mexico: Chiapas: La Trinitaria, Lagunas de Montebello; "El Aguacero", 16 km W Ocozocoautla.

\section{Lampetis (Spinthoptera) viridimarginalis sp. $\mathbf{n}$.}

\section{(Figs 30, 60)}

Diagnosis. Ventral surface metallic red with greenish and brassy tinge, punctures bright green; dorsal surface with punctures bright green margined with dark green; punctures with short, recumbent, white setae; first antennal segment metallic red with greenish tinge, the rest black with reddish and greenish or bluish tinge; pronotum metallic red medially, metallic red with green tinge laterally; elytra metallic red medially, bright green laterally, apices reddish; first abdominal ventrite slightly concave along midline, other ventrites convex.

Male description. Length 17.9-22.7 mm; width 6.1-7.9 mm. Head: Punctures bright green; labrum metallic red with green and brassy tinge, with numerous small, shallow punctures; clypeus metallic red with green and brassy tinge, anterior margin concave, without punctures medially, with few small, deep punctures; frons metallic red with brassy tinge, sinuate, with numerous small, deep, confluent punctures and strong callosities; vertex metallic red; bases of mandibles metallic red with brassy tinge, with numerous small, deep punctures, confluent near apices; maxillary palpi metallic red. Pronotum: 1.5 times wider than long, widest at middle; lateral margins slightly subparallel at base, weakly expanded at middle and obliquely converging to anterior angles; narrowest anteriorly; lateral margins carinate at middle to base; along anterior margin to middle with a 
slight, shallow line of fine, shallow, confluent punctures; anterior margin weakly bisinuate with weak median lobe; posterior margin slightly bisinuate with slight, broad median lobe; posterior angles slightly acute; disc moderately convex, flattened in midline toward base; surface with few small, deep punctures, with impunctate areas medially; laterally with numerous small, deep confluent punctures, and few callosities. Scutellum: metallic red, small, puntiform. Elytra: apices slightly and obliquely emarginate, outer and sutural angles slightly dentiform; disc convex with slightly impressed punctate striae, the striae with small, shallow punctures; surface with scarce impressions along base and scarce small, finely punctate, interstrial impressions, and intervals with few fine, shallow, confluent punctures medially, and numerous punctures and numerous small, weak callosities laterally. Prosternum: disc moderately convex; surface with numerous small, deep, confluent punctures laterally, forming weak callosities; without punctures medially; prosternal process flattened, sulci with small, shallow, confluent punctures, apex bluntly rounded. Mesosternum: surface with few small, shallow, confluent punctures laterally; without punctures medially. Mesepisternum and mesepimeron: metallic red with brassy tinge; with few small, shallow, sparse punctures. Metasternum: flattened, with few fine punctures medially, with fine setae; numerous small, deep, confluent punctures laterally. Metacoxae: with few small, shallow, sparse punctures toward external lateral margin; abundant confluent punctures at middle; scarce, fine punctures toward internal lateral margin. Femora: metallic red with greenish and brassy tinge; with numerous punctures. Tibiae: metallic red with brassy and greenish tinge; densely punctate. Tarsi: metallic red with purple and green tinge. Abdomen: first ventrite slightly concave along midline, this concavity narrow and bordered with broad, impunctate carina, and with numerous fine punctures, with numerous fine setae; other ventrites convex; apex of last visible ventrite feebly rounded with weak emargination at middle; abdominal surface with abundant small, shallow, confluent, irregular punctures with abundant setae. Male genitalia as in figure 60 .

Female. Length $20.4-24.3 \mathrm{~mm}$; width $7.0-8.6 \mathrm{~mm}$. Differs from male as follows: more robust; apex of last visible abdominal ventrite slightly rounded.

Variation. This species varies in the coloration: dorsal surface metallic red to reddish black with purple and cupreous tinge medially, and bright green to bluish green laterally; ventral surface metallic red to red-coppery.

Differential diagnosis. Lampetis viridimarginalis $\mathrm{sp} . \mathrm{n}$. is similar to L. chalconota. Lampetis chalconota dorsal surface is red-coppery medially, bright green laterally; ventral surface bright red-coppery; first antennal segment bright green, the rest dark brown with bright green and violet or blue tinge; pronotal lateral margins slightly concave, expanded at middle, then obliquely converging to anterior angles; elytral color red-coppery as far as the fourth striae, bright green toward lateral margin, apices bright green with blue tinge, disc with feebly impressed punctate striae and with finely punctate interstrial impressions, usually isolated from each other; first ventrite slightly concave along midline, ventrite 2 slightly flattened along midline.

Type material. Male holotype: [HOND: Francisco Morazan/ $15.0 \mathrm{~km}$ NW Tegucigalpa/ 4-VIII-79 $1342 \mathrm{~m} / 14088717$ ELSleeper] (CLBC). 5(3M, 2F) Paratypes: [HONDURAS: D.C./ 8 km SE Tegucigalpa/ 27.VII.1977/ CW\&L./ O'Brien \& GB Marshall] (1M, CLBC); [HOND: Francisco Morazan/ 15.0 km NW Tegucigalpa/ 4-VIII-79 1342 m/ 14088717 EL Sleeper] (1M, CLBC); [GUATML. Zacapa 12-14/ km S Sn Lorenzo 1-2000\%/ June 3-6 1989/ J.E. Wappes] (1F, JEWC); [GUATML. Zacapa 12-14/ km S Sn Lorenzo 1-2000'/ June 3-6 1989/ J.E. Wappes] (1F, GHNC); [La Paz, Hond/ 10-6-81] [9864/ clase81] (1M, USNM).

Etymology. The name of this species is derived from the Latin adjective viridis (green) and substantive marginis (margin), referring to the green coloration along the lateral margins of the elytra.

Distribution. This species has been collected only in Guatemala and Honduras. State and county records include the following: in Guatemala: Zacapa: Zacapa $12-14 \mathrm{~km} \mathrm{~S}$ San Lorenzo. In Honduras: La Paz; Francisco Morazán: 15 km NW Tegucigalpa; 8 km SE Tegucigalpa.

\section{Lampetis (Spinthoptera) webbii (LeConte, 1858)}

(Figs 31, 61, 81)

Psiloptera webbii LeConte, 1858b: 66, 1860: 193; Waterhouse, 1882: 10; Kerremans, 1910: 132.

Spinthoptera webbii; Casey, 1909: 95.

Spinthoptera arizonica Kerremans, 1910: 133.

Psiloptera (Lampetis) webbii; Nelson, 1986: 281.

Diagnosis. Head, bases of antennae and mandibles blue, apices of antennae black; dorsal surface dark bluishblack; ventral surface dark blue; punctures and impressions brassy-green; elytral apices generally dark blue; frons flattened; pronotal lateral margins obliquely converging anteriorly, disc moderately convex, flattened along midline to posterior margin; elytral disc with many punctate interstrial impressions, usually isolated form each other, striae feebly impressed, apices not dentiform; first ventrite with midline concavity usually bordered by smooth broad carina and ventrite 2 slightly flattened in midline. Male genitalia as in Fig. 61.

Distribution. From 125 males and 174 females examined, this species has been collected in northern Mexico and USA State and county records include the following: in Mexico: Chihuahua: Santa Bárbara; Km 36, Santa Bárbara-Ojito; Santa Clara Canyon, $5 \mathrm{mi} \mathrm{W}$ Parrita; Hidalgo de Parral; $33 \mathrm{mi} \mathrm{S}$ Parral; 32 mi S Hidalgo de Parral; Durango: 24 mi N La Zarca; Sonora: $9 \mathrm{mi}$ NNE Imuris; $11 \mathrm{mi} \mathrm{N}$ Imuris. In USA: Arizona: Bisbee; Graham; Cochise; Santa Cruz; Pima; Pinal; New Mexico: Hidalgo; Texas: Cochise; Brewster.

Adult host plants. Acacia greggii, Prosopis juliflora (Fabaceae), Bumelia lanuginose (Sapotaceae), Larria mexicana, Quercus arizonica, Q. oblongifolia, and $Q$. sp. (Fagaceae).

Phenology. Collected from January to December.

ACKNOWLEDGEMENTS. I thank the following individuals and curators for the loan of specimens and type material studied herein: G.H. Nelson, Blue Springs, Missouri; D.S. Verity, Los Angeles, California; F.T. Hovore, Santa Clarita, California; J.E. Wappes, Bulverde, Texas; M.A. Ivie, Bozeman, Montana; T.C. 
MacRae, St. Louis, Missouri; J. McCarty, San Pablo, California; R.B. Holynski, Milanówek, Poland; R.F. Morris, Lakeland, Florida; L.H. Herman, Jr., AMNH; M. Kerley, BMNH; R. Brett, CASC; C.L. Bellamy, CDFA; J. Romero, CEAM; S. Zaragoza and S. Santiago, CNIN; R. Hoebeke, CUIC; R.D. Cave, EAPZ; F.A. Noguera, EBCC; J.A. Chemsak and C.B. Barr, EMEC; W. Hanson and F. Merickel, EMUS; P.P. Parrillo, FMNH; B. Beck, FSCA; A. Solis, INBC; J. Cools, ISBN; P.D. Perkins, MCZC; K.A. Guerrero, MHND; J. Clavijo, MIZA; J.J. Morrone, MZFC; H. Silfverberg, MZHF; S. Bílý, NMPC; R.L. Westcott, ODAC; J.M. Maes, SEAN; R. Brooks, SEMC; J. Luna, UAQC; S.L. Heydon, UCDC; D. Yanega, UCRC; J.L. Navarrete, UGZM; D. Mann, UMO; D.G. Furth and S. Lingafelter, USNM; M. Uhlig, ZMBH; O. Martin, ZMUC. I thank C.L. Bellamy, J.J. Morrone, G. Pérez, S. Zaragoza, and R.L. Westcott for reviewing the manuscript and making helpful suggestions. I thank two anonymous reviewers for helpful comments. I thank A. Fortino for helping me to arrange the photographs in the plates. I thank CONACYT and DGEP-UNAM for supporting my doctoral studies.

\section{REFERENCES}

Aкіунма K. \& Онмомо S. 1994: Notes on the genus Lampetis Spinola from Indochina (Coleoptera, Buprestidae). Entomol. Rev. Jpn. 49: 17-24.

Arnett R.H., Samuelson G.A., Heppner J.B., Nishida G.M., Watt J.C. \& Woodruff R.E. 1993: The Insect and Spider Collections of the World. 2nd ed. Flora \& Fauna Handbook, No. 11. Sandhill Crane Press, Gainesville, FL, 310 pp.

Bellamy C.L. 1985: A catalogue of the higher taxa of the family Buprestidae (Coleoptera). Navors. Nas. Mus. Bloemfontein 4: 405-472.

Bellamy C.L. 1998a: A clarification of authorship of buprestid genera originally defined in the catalogues of P.F.M.A. Dejean (Coleoptera, Buprestidae). Fragm. Entomol. 29[1997]: 365-382.

Bellamy C.L. 1998b: Type species designations in the family Buprestidae (Coleoptera). Dt. Entomol. Z. 45: 9-15.

Bellamy C.L. 2003: An illustrated summary of the higher classification of the superfamily Buprestoidea (Coleoptera). Folia Heyrovsk. (Suppl.) 10: 1-197.

Bellamy C.L. 2004: Nomenclatural reversals in Buprestidae (Coleoptera). Pan-Pac. Entomol. 79: 258-259.

Bellamy C.L. \& Peterson M. 2000: Contributions to the Taxonomy of Australian Buprestidae (Coleoptera). Part I: New synonymy, combinations, and names. Fol. Heyrovsk. 8: $73-100$.

BLACKWELDER R.E. 1944: Checklist of the coleopterous insects of Mexico, Central America, The West Indies, and South America. Parts 1-6. Bull. Smiths. Inst. U.S. Nat. Mus. No. 185, 1492 pp.

CARTE H.J. 1924: Australian Coleoptera - notes and new species No. III. Proc. Linn. Soc. N.S. Wales 49: 19-45.

CARTE H.J. 1929: A check list of the Australian Buprestidae. With tables and keys to sub-families, tribes, and genera (by A. Théry). Austr. Zool. 5: 265-304.

Casey T.L. 1909: Studies in the American Buprestidae. Proc. Wash. Acad. Sci. 11: 47-78.

CAZIER M.A. 1951a: The Buprestidae of the Bahama Islands, British West Indies (Coleoptera, Buprestidae). Am. Mus. Nov. 1517: 1-9.

CAZIer M.A. 1951b: The Buprestidae of North Central Mexico (Coleoptera). Am. Mus. Nov. 1526: 1-56.

Chevrolat L.A.A. 1834: Coléoptères du Mexique. Fasc. 1. Gustare Silbermann, Strasbourg, 25 pp.

Chevrolat L.A.A. 1838: Centurie de Buprestides. Rev. Entomol. 5: 41-110.
Chevrolat L.A.A. 1867: Coléoptères de l'Ile de Cuba. (Suite) Notes, synonymies et descriptions d'espèces nouvelles. Septième mémoire. Famille des Buprestides, Throscides, Eucnémides et Élaterides. An. Soc. Entomol. Fr. (Ser. 4) 7: 571-616.

Corona A.M. 2004: A new species of Lampetis Dejean from Chiapas, Mexico (Coleoptera: Buprestidae). Coleopt. Bull. 58: $159-162$.

Dalman J.W. 1823: Analecta entomologica. Holmiae, Lindh 4, $104 \mathrm{pp}$.

Dejean P.F.M.A. 1833: Catalogue des Coléoptères de la collection de M. le comte Dejean. Méquignon-Marvis, Father \& Sons, Paris, livraison 1, $96 \mathrm{pp}$.

Dejean P.F.M.A. 1836: Catalogue des Coléoptères de la collection de M. le comte Dejean. 3rd éd. Méquignon-Marvis, Father \& Sons, Paris, livraisons 1-4, 384 pp.

Dugés D.E. 1891: Descripción de coléopteros indígenas de la familia de los Bupréstidos. Naturaleza (Ser. 2) 2: 1-38, plates $1 \& 2$.

FABRICIUS J.C. 1801: Systema Eleutheratorum, ordines, genera, species: adiectis synonymis, locis, observationibus, descriptionibus. Vol. 2. Bibliopolii Academici Novi, Kiliae, 687 pp.

FISHER W.S. 1925: A revision of the West Indian Coleoptera of the family Buprestidae. Proc. U.S. Nat. Mus. No. 2522, 65: $1-207$.

FisHeR W.S. 1930: 13New West Indian Buprestidae (Coleoptera). Proc. Entomol. Soc. Wash. 32: 125-129.

Gemminger M. \& Harold E. von 1869: Buprestidae, Trixagidae, Monommidae, Eucnemidae, Elateridae, Cebrionidae. In Catalogus coleopterorum hucusque descriptorum synonymicus et systematicus. Vol. 5. Monachii, London, pp. 1347-1608.

Gistel J.N.F.X. 1834: Die Insecten-Doubletten aus der Sammlung des Herrn Grafen Rudolph von Jenison Walworth zu Regensburg, welche sowohl im Kauf als im Tausche abgegeben werden I. Käfer. George Jaquet, München, 36 pp.

Gistel J.N.F.X. 1848: Naturgeschichte des Thierreichs für höhere Schulen. Stuttgart, 216 pp., 32 pls.

GundLaCh J. 1891: Contribucion á la entomologia Cubana. Vol. 3. Habana, $494 \mathrm{pp}$.

HERBST J.F.W. 1801: Natursystem aller bekännten in-und aüslandischen Insecten, als eine Fortsetzung der Büssonschen Naturgeschichte. Der Käfer neunter Theil. Vol. 9. pp. 1-344.

Holynski R. 1988: Remarks on the general classification of Buprestidae Leach as applied to Maoraxiina Hol. Fol. Entomol. Hung. 49: 49-54.

JACQUELIN DU VAL P.N.C. 1857: Insectes. Ordre des coléoptères. In Ramon de la Sagra: Histoire fisica, politica y natural de la Isla de Cuba. Vol. 7. pp. 1-136.

Kempers K.J.W. 1923: Abbildungen von Flügelgeäder der Coleopteren. Entomol. Mitt. 12: 71-115.

KeRREMANS C. 1885: Enumeration des Buprestides décrits postérieurement au Catalogue de M.M. Gemminger \& de Harold. Ann. Soc. Entomol. Belg. 29: 119-157.

Kerremans C. 1892: Catalogue synonymique des Buprestides décrits de 1758 à 1890. Mém. Soc. Entomol. Belg. 1: 1-304.

Kerremans C. 1893: Essai de groupement des Buprestides. Ann. Soc. Entomol. Belg. 37: 94-122.

Kerremans C. 1896: Voyage de M.E. Simon au Venezuela. Buprestides. Ann. Soc. Entomol. Belg. 65: 23-29.

KerRemans C. 1900: Buprestides nouveaux et remarques synonymiques. Ann. Soc. Entomol. Belg. 44: 282-351.

KerRemANS C. 1903: Genera Insectorum, Coleoptera, fam. Buprestidae. Fasc. 12b; 12c;12d. Verteneuil and Desmet, Bruxelles, pp. 49-338.

Kerremans C. 1910: Monographie des buprestides. Dulau \& Co., London; Author, Bruxelles; R. Friedländer \& Son, Berlin, Vol. 4, livraison 6, pp. 161-192; livraison 7, pp. 
193-224; livraison 8, pp. 225-256; livraison 9, pp. 257-284; color plates 23-26. Vol. 5, livraison 1, pp. 1-32; livraison 5, pp. 129-160; livraison 7, pp. 193-224; livraison 8, pp. 225-256; color plates 27-32.

Kunosawa Y. 1993: Reorganization of the genus Psiloptera (Coleoptera, Buprestidae). Jpn. J. Entomol. 61: 577-583.

LACORDAIRE J.T. 1857: Histoire Naturelle des insectes. Genera des coléoptères ou exposé méthodique de critique de tous les génères proposés jusqu'ici dans cet ordere d'insectes. Vol. 4. Roret, Paris, $554 \mathrm{pp}$.

LAPORTE de CASTelnau F.L. \& Gory H.L. 1836: Histoire naturrelle de iconographie des insectes coléoptères. Monographie des buprestides. P. Duménil, Paris. Vol. 1, livraisons 8-11, genera: Bubastes, Aurigena, Capnodis, Buprestis, pp. 1-64 [genera paged separately].

Laporte de Castelnau F.L. \& Gory H.L. 1837: Histoire naturelle de iconographie des insectes coléoptères. Monographie des buprestides. P. Duménil, Paris. Vol. 1, livraisons 12-16, genera: Buprestis, Nascio, Archerusia, Asthraeus, Bulis, Acantha, Apatura, pp. 65-160 [genera paged separately].

LeConte J.L. 1852: Remarks on some Coleopterous Insects collected by S.H. Woodhouse in Missouri Territory and New Mexico. Proc. Acad. Nat. Sci. Philadelphia 6: 65-68.

LeConte J.L. 1858a: Catalogue of Coleoptera of the regions adjacent to the Boundary line between the United States and Mexico. J. Acad. Nat. Sci. Philadelphia 4: 9-42, 4 plates.

LeConte J.L. 1858b: Description of new species of Coleoptera, chiefly collected by the United States and Mexican Boundary commission; under Major W.H. Emory, U.S.A. J. Acad. Nat. Sci. Philadelphia 10: 59-89.

LeConte J.L. 1860: Revision of the Buprestidae of the United States. Trans. Am. Phil. Soc. (Ser. 2) 11[1859]: 187-258.

MANNERHEIM C.G. von 1837: Enumération des Buprestides, et description de quelques nouvelles espèces de cette tribu de la famille des Sternoxes, de la collection de M. Le Comte Mannerheim. Bull. Soc. Imp. Nat. Moscou 8: 1-126.

Nelson G.H. 1976: Lectotype designations in the Mannerheim Collection of Buprestidae at the Universitetets Zoologiska Museum, Helsingfors, Finland. Coleopt. Bull. 30: 167-168.

Nelson G.H. 1982: A new tribe, genus and species of North American Buprestidae with consideration of subfamilial and tribal categories. Coleopt. Bull. 35[1981]: 431-450.

Nelson G.H. 1986: A review of the genus Psiloptera subgenus Lampetis Solier in the United States (Coleoptera: Buprestidae). Coleopt. Bull. 40: 272-284.

Nelson G.H., Westcott R.L. \& MacRae T.C. 1996: Miscellaneous notes on Buprestidae and Schizopodidae occurring in the United States and Canada, including descriptions of previously unknown sexes of six Agrilus Curtis. Coleopt. Bull. 50: 183-191.

OBenBerger J. 1924a: De buprestidarum speciebus novis (diagnoses praeliminares) (Col.). Nové druhy čeledi krasců. Sborn. Entomol. Odd. Nár. Mus. Praze 2: 93-115.

OBenberger J. 1924b: Kritische studien über die Buprestiden (Col.). Arch. Naturg. Vol. 90 Abt. A, Heft 3, pp. 1-171.

OBenberger J. 1926: Buprestidae I. In Junk W. \& Schlenking S. (eds): Coleopterorum catalogus. Vol. 12, pars 84. Berlin, 212 pp.

Obenberger J. 1930: Buprestidae II. In: Junk W. \& Schlenking S. (eds): Coleopterorum Catalogus. Vol. 12, pars 111. Berlin, pp. 213-568.

Obenberger J. 1934: Sur les Buprestides du Musée de Milano (Col. Bupr.). Att. Soc. Ital. Sci. Nat. 73: 49-56.

Obenberger J. 1937: Spedizione del Prof. Nello Beccari nella Guiana Inglese 1931-32. Buprestidae. Boll. Soc. Entomol. Ital. 69: 99-101.
ObenBeRger J. 1958: Buprestides, trouvés par l'expedition chino-soviétique 1955 en Chine méridionale (Col. Buprestidae). Act. Soc. Entomol. Cechoslov. 55: 223-243.

OLIVIER A.G. 1790: Entomologie, ou histoire naturelle des insectes, avec leurs caractères génériques et spécifiques, leur description, leur synonymie, et leur figure enluminée. Coléoptères, genera 9-34, Vol. 2, no. 32. Baudouin, Paris, 63 plates, $485 \mathrm{pp}$.

RIKHTER A.A. 1952: Fauna of the USSR, N.S. No. 51, Coleoptera (Buprestidae). Vol. 13, no. 4. Moscow-Leningrad, 234 pp.

SAUNDERS E. 1871: Catalogous buprestidarum synonymicus et systematicus. J. Janson, London, $171 \mathrm{pp}$.

SCHAEFFER C.F.A. 1905: Some additional new genera and species of Coleoptera found within the limit of the United States. Sci. Bull. Mus. Brooklyn Inst. Arts Sci. 1: 141-179.

SCHÖNHERR C.J. 1817: Synonymia Insectorum, oder Versuch einer Synonymiealler aller bisher bekannten Insecten nach Fabricii Systema Eleutheratorum geordnet, mit Berichtigungen und Anmerkungen wie auch Beschribungen neuer Arten und illuminirten Kupfern. Vol. 1 (3), Hispa - Molorchus, Skara, Lewerentz, xi +506 pp. (Appendix ad C.J. Schönherr Synonymia Insectorum, tom. 1, part 3, sistens descriptiones novarum specierum, illus. Scaris, 266 pp.)

Sinola M. 1837: Lettre adressé à la Société Entomologique de France, sur un groupe de Buprestides. Ann. Soc. Entomol. France 6: 101-122.

THÉRY A. 1905: Révision des Buprestides de Madagascar. Emile Deyrolle, Paris, 186 pp.

THÉRY A. 1923: Etudes sur les Buprestides. (Troisième partie). Ann. Soc. Entomol. Belg. 62[1922]: 193-270.

THÉRY A. 1927: Etude sur les Coléoptères Buprestides appartenant aux collections des grands musées (1-ère note: British Museum.). Ann. Soc. Entomol. Fr. 96(3-4): 247-261.

THÉRY A. 1946: Buprestides d'Angola. Arqu. Mus. Boçage 17: 1-132. [continued 1947c]

THÉRY A. 1948: Buprestidae (Coleoptera Sternoxia). Exploration du Parc National Albert, Mission G.F. de Witte (1933-1935), Fasc. 54, 85 pp.

Thomson J. 1878: Typi Buprestidarum Musaei Thomsoniani. E. Deyrolle, Paris, 103 pp.

Thomson J. 1879a: Typi Buprestidarum Musaei Thomsoniani, Appendix 1a. E. Deyrolle, Paris, 87 pp.

Thomson J. 1879b: Revue du groupe des Psiloptérites; Description d'espèces nouvelles de Psiloptérites. Rev. Mag. Zool. 7: 161-177.

Vogt G.B. 1949: A biologically annotated list of the Buprestidae of the Lower Rio Grande Valley, Texas. Ann. Entomol. Soc. Am. 42: 191-202.

WATERHOUSE C.O. 1882: Biologia Centrali-Americana, Insecta, Coleoptera, Buprestidae. Vol. 3, part 1. F.D. Godman \& O. Salvin, pp. 1-32, plates 1-2.

Waterhouse C.O. 1889: Biologia Centrali-Americana, Insecta, Coleoptera, Buprestidae. Vol. 3, part 1. F.D. Godman \& O. Salvin, pp. 49-193, plates 4-8.

WATERHOUSE C.O. 1896: Observations on some Buprestidae from West Indies and other localities. Ann. Mag. Nat. Hist. (Ser. 6) 18: 104-107.

Westcott R.L., Atkinson T., Hespenheide H.A. \& Nelson G.H. 1990: New country and state records, and other notes for Mexican Buprestidae (Coleoptera). Insecta Mundi 3: 217-232.

Wickнам H.F. 1895: Note on a trip to the Bahama Islands. Can. Entomol. 27: 291-296.

Received August 6, 2004; revised and accepted February 15, 2005 